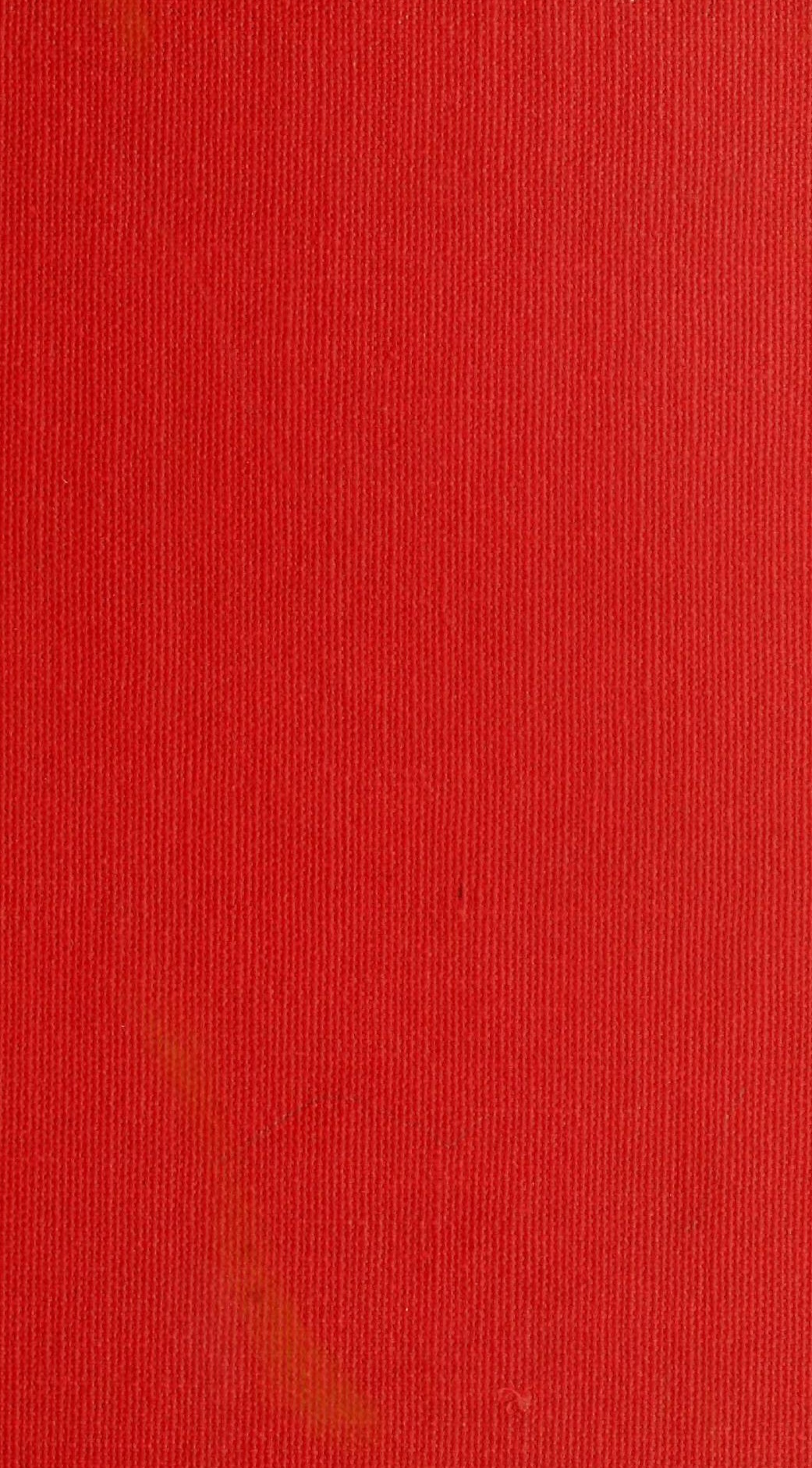




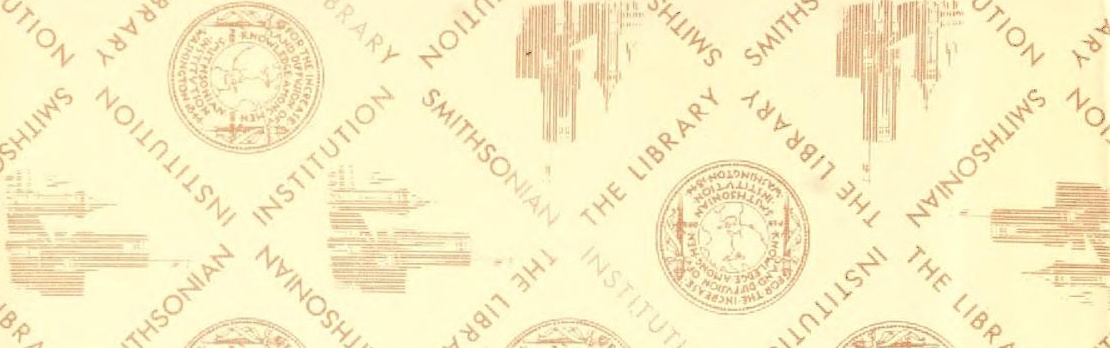

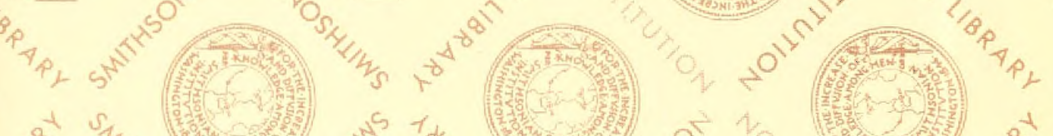
20.

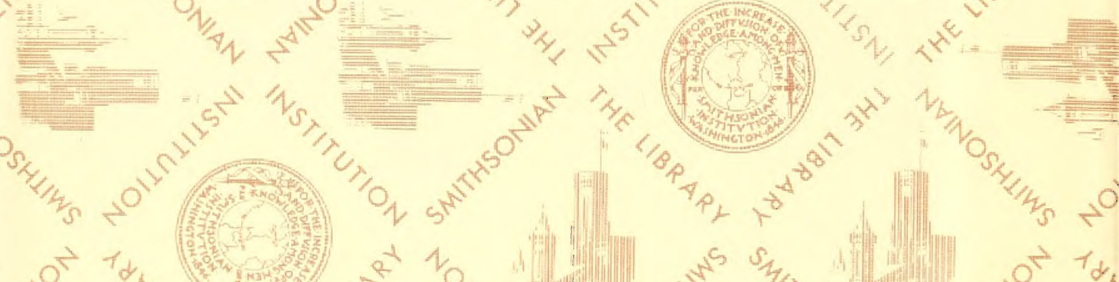

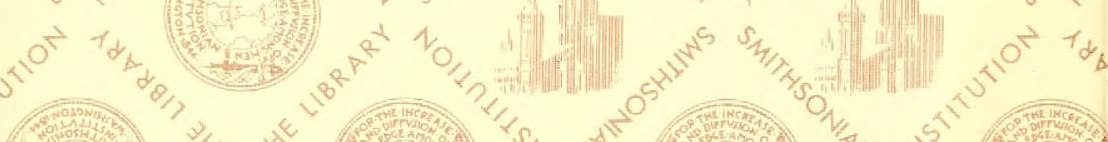

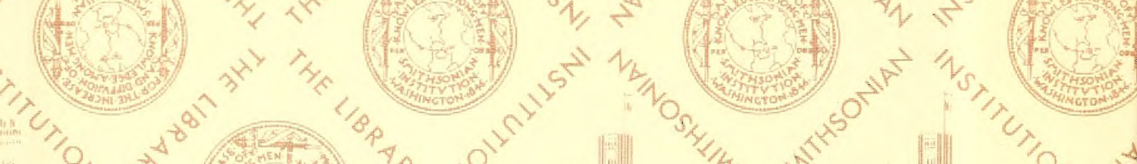

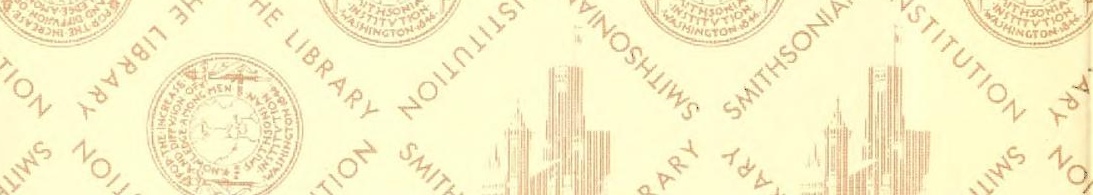

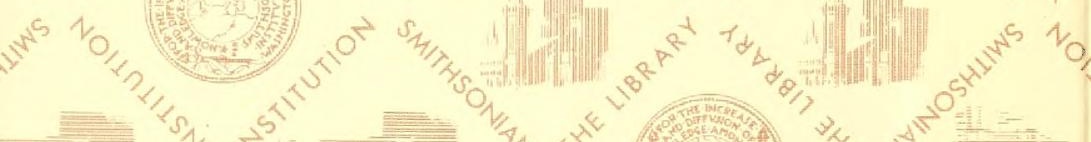

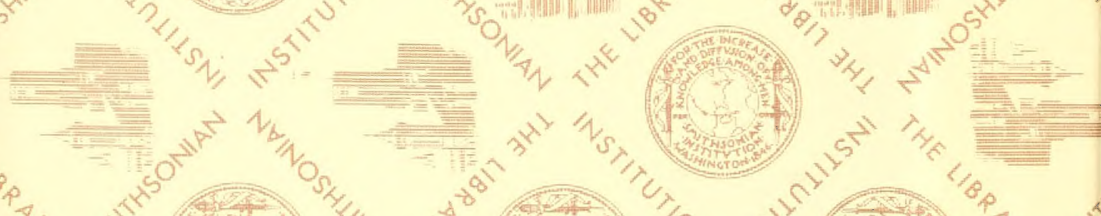

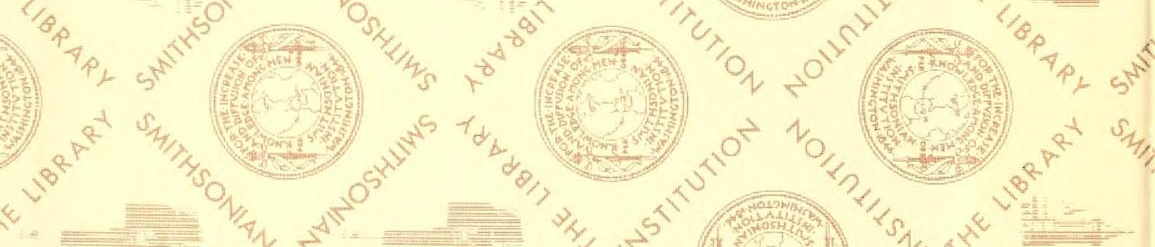

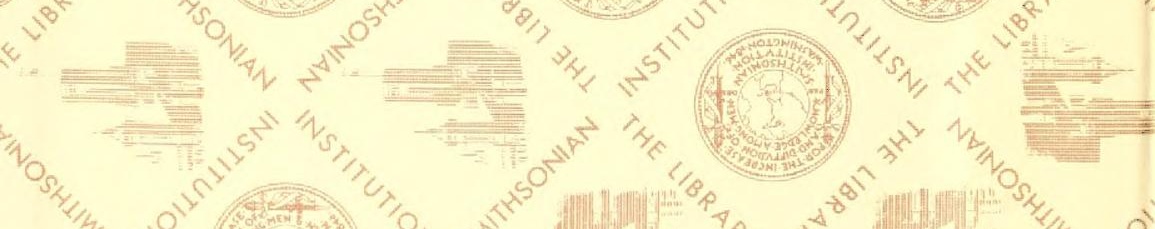

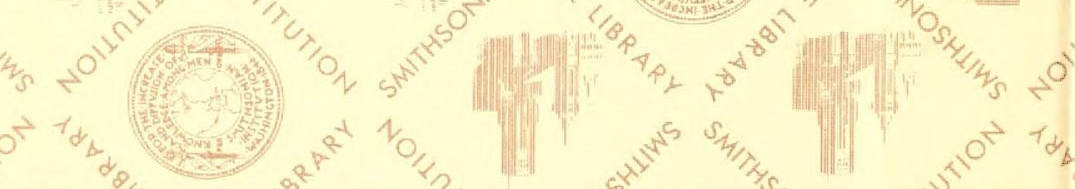

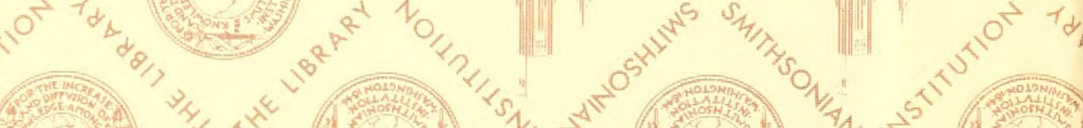

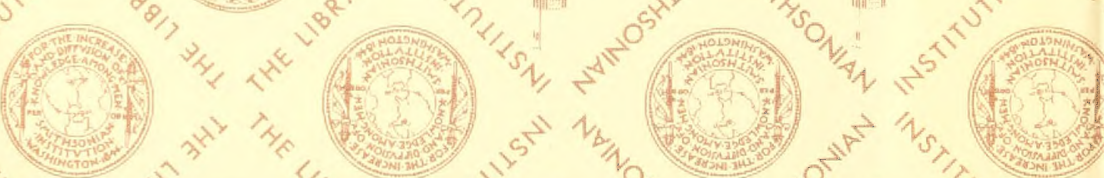

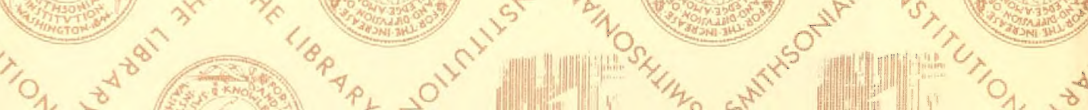




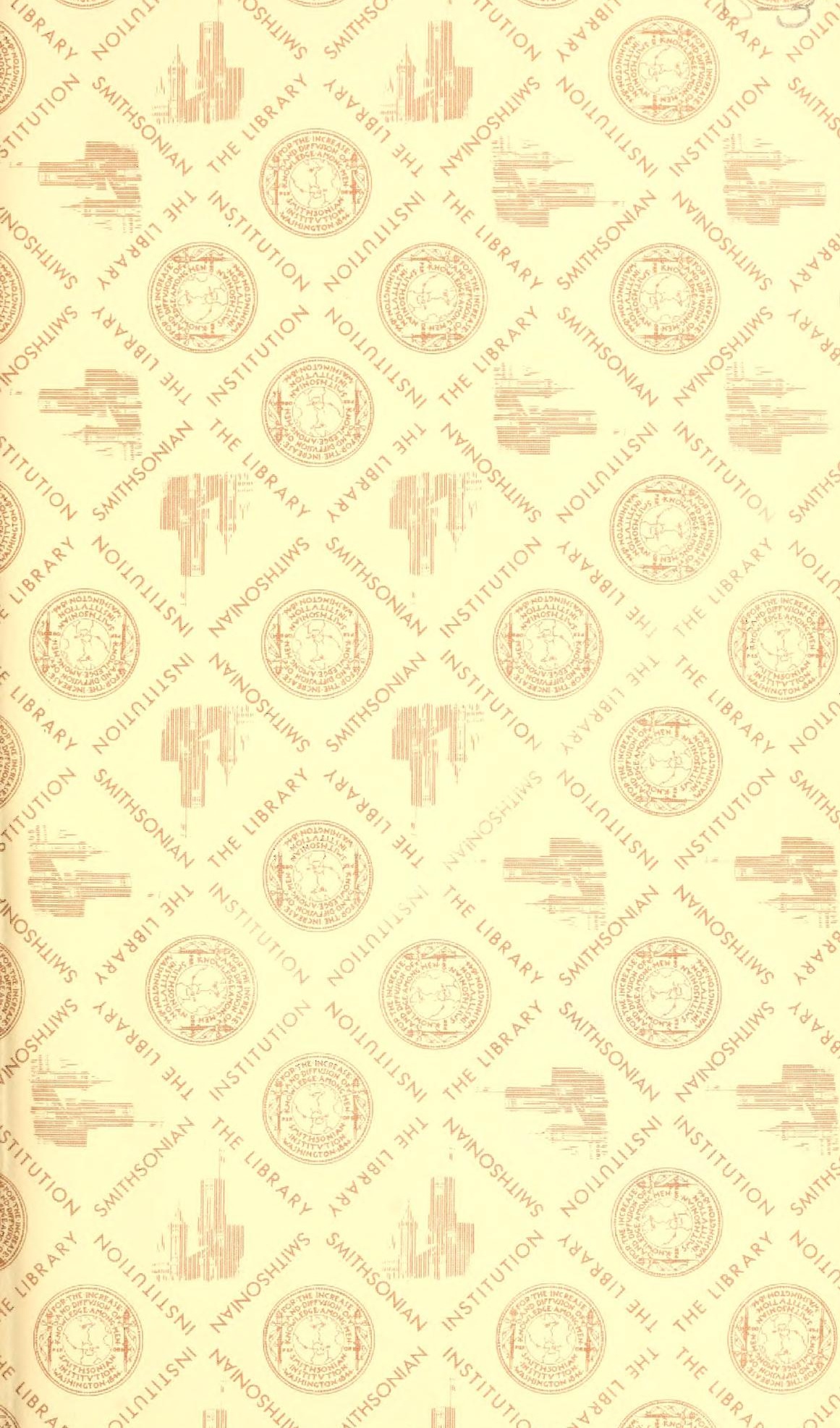





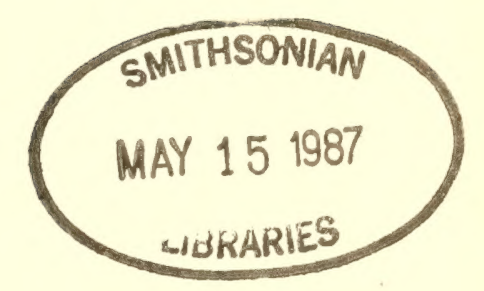





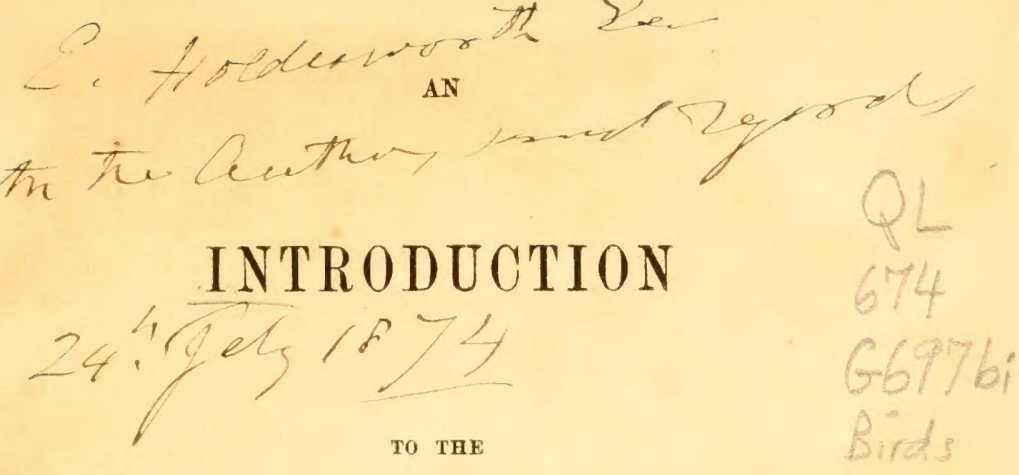

\section{BIRDS OF GREAT BRITAIN.}

BY

JOHN GOULD, F.R.S., \&c., \&c.

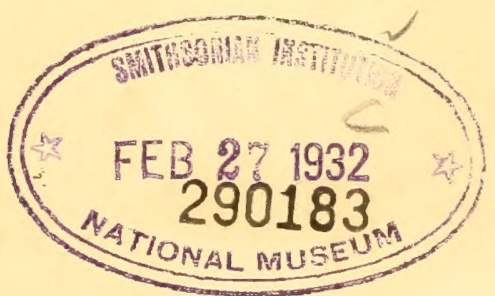

L O N D O N :

PRINTED FOR THE AUTHOR, BY TAYLOR AND FRANCIS, RED LION COURT, FLEET STREET.

1873.

[Price Five Shillings and Sixpence.] 

THE RIGHT HONOURABLE

\section{ROWLAND, VISCOUNT HILL, \\ OF HAWKSTONE,}

LORD LIEUTENANT AND CUSTOS ROIULORUM, COUNTY OF SALOP,

\section{THIS WORK}

oN

\section{THE BIRDS OF GREAT BRITAIN}

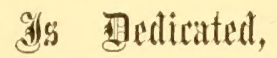

- BY THE AUTHOR,

IN

TESTIMONY OF HIS SINCERE RESPECT AND REGARD

AND IN

COMMEMORATION OF

AN UNINTERRUPTED FRIENDSHIP OF MORE THAN FORTY YEARS. 



\section{PREFACE.}

The question may naturally suggest itself to some of my readers, what object I had in riew in publishing a work on the Birds of Great Britain, when I had already completed a similar publication on the arifamma of Europe. My reasons are simply these:Before the latter was completed the eutire edition was all or nearly all sold; and rery many persons interested in this department of science were disappointed in not being able to procure a copy of a work which they saw in the hands of so many others. Consequently, on the completion of my 'Birds of Australia,' at the solicitation of a large number of pricate friends and others, and influenced by the inereased taste for natural history that had sprung. up in the interim, I "returned to my old lore" by publishing the British Birds, excluding those of the continent, thus complying with the wishes of those persons who have cspecially paid attention to our native ornithology. I also felt that there was an opportunity of greatly enriching the work by giving figures of the young of many of the species of various genera- a thing hitherto almost entirely neglected by authors; and I feel assured that this infantile age of bird-life will be of much interest for science, to my subscribers, and to readers generally.

That my efforts to render this publieation a standard work hare been successful is evidenced by its sale being double that of any other work I have given to the public. Many of the numerous oruithologists who have arisen within the last few years have rendered me much raluable information-a kindness which I duly acknowledge, and trust that, although not specially mentioned in this short Preface, they will take it for granted they have not been forgotten, and that their names lave been generally associated with the various subjects to which their communications have reference.

Many of the public are quite maware how the colouring of 
these large Plates is aceomplished; and not at few believe that they are produced by some mechunical process or by chromo-lithography. This, howerer, is not the ease; every sky with its varied tints and every feather of each bird were coloured by hand; and when it is considered that nearly two hundred and eighty thousand illustrations in the present work have been so treated, it will most likely cause some astonishment to those who give the sulject a thonght.

I am truly and sineerely thankful for the blessing of health which has attended me during the course of my twelve years' labour on the present work; and it was only while the Introductory matter was going through the press that a serere blight fell upon me (the untimely death of my youngest son, Dr. Franklin Gould*), and east a gloom over my future happiness. I should not have alluded to this painful subject here did I not feel it was only doing justice to his memory, inasmuch as he rendered me much assistance in the composition of the following Introduction, which, from his varied acquirements, he was well qualified to give. His loss has called forth the sympathy of many kind friends, which has in some measure assuaged the sad afflietion which has befallen me. If I am spared it is my intention not to be idle; for although $I$ do not entertain the idea of entering upon any new enterprise, I shall still pursue the subject with the same euergy I have hitherto done,at one period of the year attending to the Birds of Asin, at another to the recent discoveries in the ornithology of Australia, pursuing the subject to New Guinea and the adjacent islands, the arifaunas of these latter countries being inseparable.

It gives me great pleasure to state that my Secretary, Mr. Prince, after twelve months' of very severe illness, is again able to render me his assistance, that Mr. Wolf affords me the benefit of his talented pencil, and that Mr. Richter and Mr. Hart continue their services as heretofore.

JOHN GOULD.

Norember 1,1873 .

* Dr. F. Gould died of fever on board the Steamship 'Behar' on the 19th of Mareh last, during his passage from India to Suez, and was buried the same day in the Red Sea. 


\section{TO THE READER.}

Is pursuance of the course adopted when preparing the introductory matter of my works on the 'Birds of Australia,' the 'Mammals' of the same country, and the 'Monograph of the Trochilidæ,' I have had the ' Introduction to the Birds of Great Britain' set up in small type for the convenience of correction before printing it for the folio work; by this means I have been enabled to review the entire subject, to draw up a complete list of the species I have thought it advisable to include in the British avifauna, and to make those corrections and additions which have become necessary while the work was in progress.

It should be borne in mind that this 'Introduction' is not intended in any way in substitution for the letterpress already published in the folio work, but rather in augmentation of what is there stated and as a general summary. Those who do not already possess the folio edition will not be able to dispense with it on the acquisition of the present volume, while, it is hoped, it will be found a useful supplement and index. 



\section{INTRODUCTION.}

Is the olden time when the wolf and the wild boar roamed over the primitice forests of (ireat Britain, when the beaver held its own in our silent and undisturbed stre:tms and lakes, when the red deer followed our mountain tracks in all the rigour of its pristine condition, when our marshes and great sedge-covered watery wastes were yearly visited by the Crane and the Spoonbill, the earliest dawn of natural history which was to herald the light of future ages had not jet broken upon the untutored Celt, who alone shared with those animits the possession of our islands. With the progress of civilization that obseurity has been gradually dispelled; and, happily for our country, from the time when Gilhert White wrote his charming account of Selborne, the study of natural history, more particulariy with reference to our native birds, has gradually increased, until its pleasures hare become widely known to both young and old. The talented Bewick rendered the sulject still further attractive by his inimitalle and truthiful drawings: then followed in the same path Selby, Macuillivray, Thompson, and Yarrell, whose writings have made this branch of science so popular that it now engrosses the minds of thousands. Of the truth of this statement ample evidence is afforded by the numerous works (both great and small) which have been recently published, by the many local faunas which have lately appeared, and by the establishment of naturalists' clubs and associatious in many parts of the country. Such has been the impetus given by these means to the study of natural bistory that. it will scarcely be presumptuous in me to foretell that a period is not far distant when our native birds will be far more familiarly knomn to the people than they now are. For, although it may appear surprising to many of my readers, I assert that at the present time there are but few persons who could enumerate by name eren a fourth part of the birds with which we are surrounded. Country people are fumiliar enough with the call of the Wryneck, the voice of the Cuckoo, and the crake of the Landrail; but few, rery few, would recognize those birds if placed before them. Will it not, then, be well to encourage the formation of natural-history societies to the utmost, and doing so enlighten the minds of those who have hitherto been much in ignorance? With this spread of knowledge, mythical traditions such as that of the hiberuation in caves or under water of such a bird as our common Swallow (traditions not confined, as might be presumed, to a remote country village, but which from time to time have found utterance in the lips of educated people) will happily cease to exist; while the timid rustic, gradually freeing himself from the countless superstitions connected with many of our birds, will no longer pause with bated breath when startled at night by the not very cheerful cry of the Screech-Owl. To be in the country and not to care to recognize or be able to discriminate between the musical notes of the Thrush, the plaintive song of the Blackbird, the carol of the Lark, or the exquisite lay of the 
Nightingale, is to me surprising ; yet that such people exist is but too well known. Shakespeare and our earlier poets duly appreciated, however, the varying melodies of our feathered songsters, and have never been slow to accord to each its well-carned tribute of praise :-

"It was the nightingale, and not the lark,

That pierced the fearful hollow of thine ear ;

Nightly she sings on yon pomegranate-tree;

Believe me, love, it was the nightingale." -

Romeo and Juliet, act iii. scene 5.

Again :-

"The busy larke, messager of daye,

Salueth in hire song the morwe gray:

And fyry Phebus ryseth up so bright,

That al the orient laugheth of the light."-

Ciraucer, Knightes Tale.

Or :-

"Hark how the cheerefull birds do chaunt theyr laies,

And carroll of loves praise.

The merry larke hir mattins sings aloft,

The thrush replyes, the mavis descant playes,

The ouzell shrills, the ruddock warbles soft;

So goodly all agree with sweet consent

To this dayes merriment." -

SPENCER, Epithalamion, 1595.

The study of natural history reveals to us a wide field, pregnant with interest and pleasure. The geologist, who, from the various aspects of nature, attempts to form a conception of how this planet has been formed, and the naturalist, whose senses are keenly alive to the beauty and importance of the manifold liring objects which meet his gaze on every side, are pursuing a course calculated to lead to the highest and happiest results. Even the humble cottager who decorates his windows with flowers, and the artisan who keeps and encourages his little birds to sing and to solace him, are imbued with tastes of a superior order, which, if properly cultivated, cannot fail to induce a greater intellectual development, and consequently an increase in happiness.

Granted that the antiquary in poring orer some dusty relic of a hy-gone age experiences a thrill of pleasure denied to others, or that the wealthy man filling his rooms with the finest efforts of the artist's pencil, and his cabinets with articles of rare and costly workmanship, thereby experiences a very high degree of gratification, or eren that the man of pleasure, fulfilling the daily routine demanded by fashion, finds in it some irresistible attraction-yet what are these enjorments compared with those daily and hourly offered to the student of nature! Does he not see in the growth of a blade of grass, or in the mechanism which enables the tiny gnat to effect the countless ribrations of its gauzy wings, or in the majestic ease of the soaring nagle, evidences of a power and skill immeasurably superior to those 
ever originated by man ? Can he walk in the fields without secing and hearing around him sights and sounds which, while tending to make him more and more thoughtful, deeply impress him with a sense of the wisdom, the power, and the beneficence of his Creator? That man who has passed his allotted time in ignorance of the teeming worlds of life around him, has had denied to him pleasures and delights the experience of which must have gone far to elevate the noblest of God's created beings. "The study of ornithology has always been a farourite one with me," says the late Mr. Wheelwright, "and is one of the few innocent pleasures of youth which follows a man into maturer years, and upon which he can look back in the dechine of life with feelings of pure and unalloyed delight. Man's constant companions in erery outdoor occupation, cheering him with their presence and their songs, and often affording him a principal means of subsistence, it is little wonder that the study of the habits and instincts of birds should be a farourite one with most persons; and to him whose time is quietly and happily spent in the forests and the fields it adds one of the truest zests to rural life."

Notwithstanding the limitation of area implied in a work entitled - The Birds of Great Britain,' the most elementary student of natural history must acknowledge that in numbers and in interest, if not in beauty of marking, our avifauna will bear a farourable comparison with that of other countries of similar extent. The one most closely approximating to it would appear to be that of Japan-a fact sufficiently surprising when we remember the rast continent embracing many degrees of longitude stretching between the two. But the resemblance may possibly be explained by the similarityexisting in their physical conditions and in the general character of their natural productions. Both countries are blessed with a temperate climate especially suited to similar forms of bird-life, some species identically the same occurring in cach; but, in addition, Great Britain offers in its numerous islets, its rocky promontories and extensire marshes, its natural forests and heathy expanses, certain advantages of locality not perhaps enjoyed by Japan to the same extent, and which are singularly well adapted to forms of the most opposite linds.

One feature of especial interest must always strike the naturalist in studying the birds of the temperate zone, riz. the alternation of its feathered immigrants, which lends such a charm to the scenery, a charm which is greatly euhaneed when we reflect that these migratory morements are governed by certain infallible laws. Thus the arrival and departure of the Swallow, the Cuckoo, the Landrail, \&c. is as strictly regulated as the recurrence of the seasons:

"Yea, the Stork in the hearens knoweth her appointed times; and the Turtle and the Crane and the Swallow observe the time of their coming."

Besides being tenanted by about one hundred and fifty stationary species, Great Britain has migrants and occasional visitants from the four points of the compass; thus, in spring, nearly fifty species risit us from the south-whilst in the autumn our milder and more equable climate attracts a still larger number from the north, who instinctively know they will here find that food and shelter which the rigorous 
winters of more northern regions deny to them. In addition to this true and characteristic migration, our islands are occasionally resorted to by certain species which, from some unknown cause, make a morement from east to west; whilst the pseudo-migration from west to east is exemplified in the rarely occurring $A$ merican forms which from time to time have been recorded, and which, blown off from their native shore, find in the masses of seaweed, uprooted trees, and portions of wreck constantly approaching our coasts through the agency of the Gulf Stream, that means of rest and recruitment which finally enables a few of them to reach a welcome though far distant haven. A remarkable degree of capricionsness, which to me has always appenred mysterious, occurs in the choice of localities affected by certain of our migrants: thus the Pied Flycatcher will not rest until it has reached the middle and northern counties of England, while the Nightingale almost restricts its visit to the southern, eastern, and central ones, never farouring Cornwall with its presence, and but rarely going into Deronshire or Wales, or further north than Torkshire or Durham. Again, some species, exemplified in many of the Plovers and Sandpipers, make our islands but a halting-place, pausing for rest only on their way to unknown and probably far distant regions.

The mrsterious law or laws which govern migration must always be regarded by the naturalist with the utmost interest. Within our own islands hardly a month passes by without the morement of some species occurring to remind us of the existence of such a principle. In the early spring, before the Wheatear, that earliest of our visitors from the sunny south, has arrived, the Fieldfure and Redwing which during the winter have peopled our hedgerows and fields, the Geese, Ducks, and numerous wading-birds which have been frequenting our broads and rivers, hare, in obedience to nature's prompting, eommenced a movement northward, en route for localities better suited, by their quietude and by the nature of the food found there, for the propagation and rearing of their progeny; then, as the rass of the life-inspiring sun strike upon our earth with daily increasing strength, we begin to welcome in quick succession those little feathered arrivals which make the spring and early summer seasons of so much enjoyment and anticipation to all true lovers of nature. March, besides the Wheatear, brings us the Chiffchaff and the Sand-Martin ; April's earliest days herald in the Swallow, Wryneck and Martin; br the middle of that month the Nightingale has made its appearance, together with a host of other sylvan species: soon after, the Cuckoo and Landrail arrive; and on the joyous First of Mas the latest of all comers, the Swift, the Nightjar, and Flycatcher may be looked for. A pause of a few weeks follows; and, reprodurtion having been acenmplished, then commences, as it were, the ebr) of the great tide of migration. The Swift, which, as we have seen, was one of the latest to arrive, is the first to depart; then the Landrail makes gnod its retreat to the more southern country of Afriea ; other kinds follow in succession, all hastening to make their escape before such changes of climate and natural conditions have 
set in as would prove fatal to their existenes, either on account of the lowering of the temperature or the cessation of suitable food. By the end of Feptember the great mass have departed, and only a scanty remnant are to be met with. With this same ebb, the autumnal months bring to our sight again strings of grallatorial and natatorial birds, urged by similar causes from the northern regions back towards the south in search of that food and aquatic life which the icy hand of winter had already begun to grudge them and their progeny in their summer location. 'To follow the sun appears to be the course of true migration; but the promptings of instinct which lead the swallow and many other species to quit our shores, after a brief sojemrn, for Africa, or those which lead the Fieldtare and the Redwing to quit the Norwegian 'fjelds' for our cultivated lands, must surely be comnected in some way with, if they have not for their sole object, the provision of food and climate suitahle to the species. The Rer. H. 13. Tristram remarks that "those species which have the most extended northerly have also the most southerly range, aud that those which resort to the highest latitudes for nidification also pass further than others to the southward in winter. 'Thus the migratory Fieldfare and liedwing, risiting regions north of the limits of the Thrush and IBlackbird, on their southern migrations likewise leave their more sedentary relatives behind. The Brambling, which passes the Chaffinch in Norway, leaves it also in Europe, and erosses the Mediterramean every winter to the Barbary states." (Ibis, 1865, 1. 77.$)$

The regularity, however, which oceurs in the arrivals of our summer visitants is not quite so strictly adhered to in their departures. Having accomplished the purpose for which they came, these depart again at varying periods, but mostly as soon as the renewal of their primaries will admit of their flying across the channel, leaving their young to follow instinetively (when their muscular development has been sufficiently matured) the same route by which their parents have preceded them. This apparent desertion of the young birds at a period when one would imagine the presence of their parents as leaders would be absolutely essential, seems to prevail amongst many of our migratory species. That the old birds should be able instinetively to wing their way back to whence they came is not half so marvellous as that the newly fledgexl nestling, urged by some my'sterious power, should undertake a flight extending over humdreds of miles and many variations of climate in search of a temporary home it has never seen. This irresistible impulse, which prompts the necessity of a migration somewhither, is but too sadly seen in the restless actions and almost frantic efforts of the caged 'Turtle Dove, Nightingale, or Whitethroat during the period at which, were they free, they would be learing our shore; once let that period be passerd, their efforts cease, and apparent resignation to their prison ensues. "It sometimes happens," says Mr. R. Gray, "that Swifts, obeying" their unconquerable instincts, will at the close of a stormy season desert their unfledged young, and leave them to perish of hunger. Late breeds especially are subject to this unnatural desertion. 
Oftener than once I have seen the little round sooty faces of the young ones peering out of their holes and plaintively erying for food, after which they have crept back to die. In these very nests, on the return of another season, the same old birds have been known to rearrange their building-materials, a few straws being merely laid over the bones of the abandoned to receive a new family."

It is a matter of surprise to some persons, as indeed it may be to the most astute philosopher, how such frail little birds as the Chiffchaff and its allies can cross the sea from France or Portugal without exhibiting any very apparent signs of fatigue; yet we know that they do so, and moreover that a still smaller species, the Goldcrest (Regulus cristutus), effects a much longer passage when crossing the German Ocean in its migration from the opposite parts of the Continent. I must not omit to mention, however, that oceasionally hundreds of these diminutive birds are found in an exhausted state in the early morning on the Northumberland and Norfolk coasts; and in support of this I may quote here a very interesting passage from the work of the late gifted Mr. Selby, which runs thus:- "On the 24 th and 25th of October 1822, after a very severe gale, with thick fog, from the north-east (but reering towards its conclusion to the east and south-east), thousands of the Golderests were seen to arrive upon the sea-shore and sandbanks of the Northumbrian coast, many of them so fatigued by their flight or perhaps by the unfarourable shift of the wind, as to be unable to rise again from the ground; and great numbers were in consequence caught or destroyed. The flight must have been immense in number, as its extent was traced through the whole length of the coasts of Northumberland and Durham. There appears little doubt of this having been a migration from the more northern provinces of Europe (probably furnished by the pine-forests of Norway, Sweden, \&c.), from the circumstance of its arrival being simultancons with that of large flights of the Woodcock, Fieldfare, and Redwing."

Woodcocks, we know, generally arrive in fair condition on our north-eastern shores at dawn, with a wind that is either easterly or within a point or two of that direction; but should the wind shift after their flight has commenced, the increased muscular effort required lands them on our coast in an exhausted aud emaciated state. Assuming, however, that birds, both great and small, have availed themselres of a farourable slant of wind, no great amount of muscular effort would be requisite, inasmuch as those arriving from the south will require little more than an hour to eross the Channel, while the passage of the German Ocean by those coming from the north may occupy a short night*. It is interesting to note that some of our migrants effect the passage to our shores during the night, and others by day; as a rule, it is the small sylvan birds which come at the former time, as is evidenced by numbers being found at the base of the various lighted beacons of our southern and south-eastern coasts, against which, attracted by the light, they have flown and killed

* As an evidence that birds are capable of taking very long flights with apparent ease, I may quote a letter to 'The Times' of June $27,187.2$, which 
themselves; the Swallows, the Cuckoo and the Turtle Dove, on the other hand, wing their way across in broad day-light.

Besides the regular migration of certain species, a remarkable shifting of locality occurs with others, not only in our own, but in many other parts of the world, the cause of which is totally unknown. Starlings are now very abundant in Cormwall, and Missel-Thrushes in Scotland-in which they were formerly not to be seen. Such interchanges of locality are doubtless occasionally due to alterations in the face of the country: but this was not the cause in the case of Cornwall ; for no county can have undergonc less alteration; as it was in the days of Julius Casar so it is now, unless we except the operations of mining, which naturally only affect the surface of a district to a small extent. The sudden appearance of Pallas's Sandgrouse (Syrhaptes purculoxus) in our islands and on various parts of the Continent, in $1559-60$, must be in the recollection of every one. 'This irruption of a strunge bird from the distant country of Siberia, perhaps from China, was very astonishing; and it well illustrates my meaning, which may be further exemplified by the mention of two similar occurrences in Australia. In the year 1839 the whole of the southern and eastern portions of that country was suddenly visited by millions of the littie Grass Parrakeet (Melopsittacus undulatus); and a year or two later swarms of a species of Water-hen (Tribony ventrulis) spread themselves like a cloud over the Swan-River district, destroying fields of corm and garden-produce and committing raviges muheard of before; and both these species have kept their hold until the present day, but of course in much smaller numbers. Although not necessarily bearing upon the preceding remarks, it may be here mentioned that young birds appeur to wander further from their natice homes during the first autumn or year of their existence than they do afterwards, going out, as it were, to see the world before settling down for the proper business of

further shows that the electric telegraph has not wholly deprived us of the usefulness of the Carrier Pigeon. The communication alluded to runs as follows:-

"Sin,--The promoters of the system of electric telegraphy insist on its immense superiority over the older plan of pigeon-despatches. How far these pretensions are founded on ficts is shown by the results of the pigeon-race to Brussels, which started from the Crystal Palace on Thursday last, when 72 birds were flown at noon. Immediately on their departure I telegraphed to the secretary of the society whose members had forwarded the birds, announcing their departure. The first birds arrived in Brussels at 5.28 P.s., and the telegram at 5.30 P.M.

"Another example, and I have done. During the Crimean War the intelligence was conveyed to Colombo, Ceylon, 70 miles north of Point de Galle, where the ships to India landed their despatches, and the salute fired on the news of the fall of Sebastopol resulted from information brought by them. The electric telegraph was established, and the pigeon-post abolished. I have recently been requested to restock Colombo with Belgian "voyageurs," as the information brought by the electric wire is neither so speedy nor so correct as that conveyed by the birds. The Prussians, wise in their generation, have taken lessons from the Parisians, and established pigeon-posts in Metz and their other fortificd towns. In the event of a war in which we may be engagea, what would be the value of birds that would convey messages to Jersey. Guernsey, de., when the telegraphic wires had been eut by the enemy?

W. B. TEGETMEIER," 
their lives; hence, doubtless, it is, that the young of so many of the rarer northern species (Eagles, Gulls, Divers, \&c.) are found further to the south than the old birds.

With respect to the autumnal departure of many kinds of our smaller migrants, it would appear that most, if not all of them, assemble along our south coast ready for departure on the occurrence of a farourable wind. Having once crossed the channel to France or Portugal, their further southern journey becomes an easy one, and is doubtless performed by short stages until they reach the shores of the Mediterranean, which in the case of our own birds is probably erossed at the narrowest portion, viz. Gibraltar, or some other promontory of Southern Spain, their destination being the coast of Mroroeco; on the other hand, those of Central Europe migrate by the way of Sicily and Malta to Algeria, while those which have passed the summer still further east proceed in a direct line to Egypt. North and south, and vice versit, is in my opinion their instinctive morement; and this natural impulse is so blindly followed that the Quail, when migrating, will, if possible, fly through a house or urer a mountain rather than turn aside from its conrse, which would not be the case were reason its guide; in this respect it resembles the Norwegian Lemming, whose onward course is stopped neither by lakes nor hills, and some species of ants, whose morements are equally underiating.

The British Islands and Europe generally, to which the foregoing remarks on migration almost solely refer, are, howerer, only a small portion of the globe subject to such interchanges of birdlife at different seasons of the year; the avifauna of the great continent of Asia, a continent having the loftiest mountains, the most elevated plateaux, and the richest forests in the world, is subject to similar laws. Su, again, if we cross the equator and take a riew of what occurs in the southern hemisphere, we shall find that a precisely similar morement takes place there, but of course at opposite seasons, the antipodean summer being coincident with our winter. In many instances bird-life is there represented by species of a similar form to those we find in our own country, and which erince a tendeney to a movement north and south at certain periods of the year as with us.

Although in the foregoing remarks I have used the terms migrant and migratory in their ordinary acceptation, it will be as well before quitting the subject of migration to place before my readers what I consider should be the strict meaning of the word migrant. The country a bird resorts to for the propagation of its species should be regarded as its true habitat: thus the swallows and others, although they pass only half the year in the British Islands, are really not migrants in the same sense of the term as that in which we.should so regard the Fieldfare and Redwing, who, although resident with us during the winter, retire to Norway and other northern regions for the purpose of breeding, and who are impelled to risit our country solely to obtain the food necessary for their existence. But whilst regarding the species visiting us from the north during the winter molths, such as the Woodcoek, Ducks, Fieldfires, Redwings, de., as 
true migrants only, it must be recollected that the Swallow, Chiffchaff, Cuckoo, de, species leaving us at the same portion of the vear, are migrants so far as the countries they respectively winter in are concerned.

Could a census be taken of the smaller birds inhabiting (rreat Britain, such as Sparrows, Chaffinches, Buntings \&c., and of the same birds frequenting a similar area on the Continent, there can be little doulst that the former would greatly outnumber the latter-a circumstance which may be partly due to our islands affording many more favourable localities, and partly to the fact that our smaller birds are not, as a rule, killed or eaptured for the purposes of the table, a practice which prevails abroad: of these latter, the Wheatearand the Lark are almost the only kind that are thus utilized; but to form an estimate of the numbers of the latter obtained by means of the trammel-nets of the birdcatcher, or of the former captured on the downs of Sussex and Kent, is quite impossible. The numbers of many species are, indeed, so great that no just estimate of the whole can be formed. Thus it has been computed that the Gimnets frequenting the Bass rock cannot be less than twenty thousand; how rast, then, must be the number of that speeies alone around our coasts, when we take into consideration that they are proportionally as numerous on Ailsa Craig and the other rocks on which the 5 are known to breed; the myriads also of the Dunlin and other strand-loving birds frequenting our bays and inlets are bejond all computation.

Unfortunately, however, of late years vast numbers of certain species have been destroyed, either wantonly, or for senseless purposes of decoration instigated by fishion; and to such an extent has this been carried that it has become necessary to enact laws for their protection. Whether such enactments will tend to prevent the wholesale and cruel destruetion of liobins, Kingfishers, Chaffinches, \&c. is yet to be seen; at all events if a law can be framed to put a stop to these proceedings, it will be most desirable. The magistrate, however, should have the power of acting according to his judgment when such malpractices are brought under his notice; for to suy that the St. Kildan (for whom, howerer, special exeep)tion has been made) should not take the Fulmar or its eggs, which constitute almost his sole subsistence, or that the proprietor of the Farn Islands should not collect the down of the Eider, though it may interfere with the health of the birds, or that those delicate morceaux, Plovers' egrs, should not be taken, would be ahsurd. Bird-catching should be restricted to certain seasons; the idler who spreads his nets for the capture of the Swallows that skim over the mead, or who hangs his invisible snare across the brook for the beautiful Kingfisher to fly into, the man who professedly eatches every Chaffinch in a lane, and the clever scamp who prowls round the edge of every shrubbery at daybreak for the newly arriced Nightingale, should be made to know that such practices are inadmissible, and that they have no moral right to such a course of procedure, compared with which the conduct of the old Whitechapel bird-catcher is an honest calling.

The following extract from 'Land and Water' of August 29, 1s6s, 
embodying a letter to 'The 'Times,' aptly bears out my previous remarks on the wholesale destruction recently dealt out to certain species.

"No words can convey any adequate idea of the wanton, wicked cruelty perpetraied by these ruthless slayers of unoffending birds. Broken-winged birds are abandoned, and drift away to perish by slow degrees; badly wounded birds are allowed to flutter and struggle in the bottom of the boat, their sufferings unheeded and uncared for; while many fearfully burt manage to reach the shore to die in lingering agony: and, lamentable to say, all this butchery is committed for no good purpose. We find a letter in 'The Times' headed 'A Plea for the Kittiwake,' in which it is remarked that 'some months ago a contributor to a popular journal of natural history, writing from Lincolushire, disclosed the fact that London and provincial dealers now give one shilling per head for every 'White Gull' forwardedthat one man (a stranger drawn thither for profitable occupation) boasted of haring last year killed with his own gun at Flamborough Head 4000 of these gulls-and that another sea-fowl shooter had an order from a London house for 10,000, all for the 'plume trade.' During the present summer,' it is added, 'one of these plumassiers has risited varions breeding-stations of the Kittiwake in Scotland, and laid his plans for having supplies of birds sent to him. At Ailsa Crag alone, he gare an order for 1000 Gulls per week, and there stated that he was prepared to take any quantity. To meet this demand the tacksman of the rock spread his nets while the birds were sitting on their newly hatched young, which were left in hundreds to perish on the ledges.' By reference to the letter from which the above is extracted, and which appeared in 'The Times' for August 21 st, it will be seen that an Act has this year received the Royal Assent for the preservation of sea-fowl in the Isle of Man, and that its preamble states that "the said birds are considered of great importance to the fishermen in guiding them to shoals of fish, and also for sanitary purposes by removing offal of fish from the harbours and shores."

Again, in a communication to the 'Zoologist' for January 1869, Mr. John Cordeaux says :- "The following paragraph is copied from the 'Guardian' of November 18, 1868. Comment is unnecessary. ' On a strip of coast 18 miles long, near Flamborough Head, 107,250 sea-birds were destroyed by pleasure partics in four months, 12,000 by men who shoot them for their feathers to adorn women's hats, and 79,500 young birds died of starvation in emptied nests. Commander Knocker there stationed, who reports these facts, saw two boats loaded above the gunwales with dead birds; and one party of eight guns killed 1100 in a week." "

Nature on the other hand herself at times effects similar wholesale destruction; thus a severe winter may prove fatal to many thousands of the feathered creation: in support of this assertion I annex some extracts from various sources. Under the heading "Severity of the Weather" we read in 'Laud and Water' for January 26, 1867.

"We receive from various parts of the country accounts of the 
effects of the recent cold upon all kinds of game. A correspondent of the Inverness Courier says that in Strathnairn, in common with other parts of the country, not a sprig of heather is visible anywhere, and there can be no doubt that if the snow and frost continue any length of time the destruction among all kinds of game will be beyond all precedent. Already Muirfowl are flocking in thousands to the low-lying grounds, and on Saturday last we noticed the birchwood around Craggie literally swarming with them. A farmer in Strathnairn told us that one day lately, as he entered his stable, the entire area of his courtyard was corered as 'thick as they could stand' with grouse picking up any thing they could get among the dung-heaps; and similar ' gatherings' could be told by many other farmers."

Again, in the same journal, for August 3, 1867, Mr. Henry Lee, writing of the "destruction of small birds by rain," says :-

" Iy friend Dr. Millar, of Bethnal House, Bethual Green, writes me as follows:- 'Good eridence of the severity of the rain during Thursday night (July 25th) has been afforded here in the destruction of nearly all the sparrows which congregate in our trees. My undergardener picked up one huudred and twenty-four on the following morning, and in sweeping up the fallen leaves of to-day the dead birds are being found in considerable numbers. We estimate that more than two hundred were killed." "

MIr. E. H. Rodd writing to me from Penzance under the date of January 8,1867 , says, "I foresaw that there was hard weather somewhere, although the thermometer never showed a greater amount of frost than one degree, which was the lowest reading here; 60 miles to the eastward the reading was on Wednesday nine degrees above zero, and on Thursday only tive: so much for our climate. The heary weather to the eastwarl has driren millions of Limets, Starlings, Larks, Redwings, Fieldf:res, Peerrits, and Golden Plovers to this district." As I was at the time on a visit to Lord Falmonth at Tregothnan, most of the facts mentioned by Mr. Rodd came under my own obserration; and I may add that the destruction of these birds was immense; I myself saw lying dead on the frozen snow hundreds of Starlings. Song-Thrushes, Missel-Thrushes, Redwings and Fieldfares, but none of the Common Blackbird, and noticed that sereral of the weakly birds were attacked and eaten by the Rooks, which, themselves in an exhausted state, flocked round the house and at times even approached the drawing-room windows.

Violent and heary gales also frequently lend their aid towards the destruction of bird-life, as evideneed by our shores being often found after their occurrence literally strewn with Guillemots, Razorbills, and other sea-birds; in pronf of which the folluwing instances recorded in the 'Zoologist' for 1872 may be cited.

"After the severe storm of January" says Mr. H. Rogers (writing from the Isle of Wight) "our shores from Compton Bay to Watercombe Bay were lined with Razorbills, Guillemots \&c. I had upwards of a hundred brought to me between the 25th and 31st, most of them in a rery bad condition, which had eridently perished for want of food. Seven Gemnets were also picked up and brought to 
me; this I consider very remarkable: we do occasionally get a specimen in very hard winters; but for seven of these powerful birds to be driven dead upon our shores shows the severity of the storm."

Mr. Stephen Clogg, writing from Looe two days later (February 20), says, "The south-eastern shores of Cornwall have been covered with the dead bodies of various birds during the present month. In a walk of about a mile I numbered no less than sixty-nine dead bodies of Razorbills, in various stages of decay. This state of things extends for upwards of ten miles; and when we consider the great numbers that have been carried away for the purpose of making plumes for ladies' hats, and others that did not come ashore, I think we may safely conclude that thousands of the above-named species of birls have perished in this immediate neighbourhood within a fortnight; and if such has been the case in other parts of England how vast must have been the mortality amongst them!"

To the above instances Mr. Newman, the indefatigable editor of the 'Zoologist,' adds in a note, "This morning (February 21st) I met a man going over London Bridge with a clothes-baskot full or Razorbills: he could not, or would not, tell me how he came by them; but by the blood on the plumage, I think they had come by a violent deatli."

Lastly disease, the greatest of all misfortunes, plays its sad part among birds as well as among quadrupeds and man. Grouse, as we all know, are frequently visited with great severity, and the sweeping hand of death is not satisfied until all but a remunt have succumbed to its ravages. Nature, in her wisdom, may cause all these various modes of destruction to take effect for some good end, - to check, perhaps, an inordinate increase of a particular species: quite certain it is that she nerer intended that fire thousand Grouse should be bred on a Lancashire moor, or that a thousand Blue Hares should inhabit the crown of a single seottish hill, as is often the case.

This unnatural over-crowding of the Grouse and Hares may hare arisen in the case of the former from the extreme care and attention bestowed upon them, and, as regards the latter, from the killing down of the Golden Eagles and Foxes, of whose food the Blue Hare coustitutes a large proportion, and upon the molne increase of which they were doubtless intended to afford a wholesome check.

"The jealous care," says Mr. Robert Gray, in his "Tirds of Western Scotland," "with which this beautiful bird is protected appears of late years to have affected the wellbeing of the species;" and "I cannot withold expressing a fear that the lied Grouse of Scotland, if not soon left to its own resumees, may ultimately become a victim to overprotection. The great changes that have taken place within the last thirty years in the manarement of moorland tracts, and the excessive rents now derived from such properties, induced both landowners and lessees to clear the ground of all kinds of animals that would prey upon those hirds which are not strong enough to protect themselves: hence sickly broods of Grouse perpetuate other broods, that year by year degenerate, until disease ensues, and in some 
instances almost depopulates an entire district. 'There can be no doubt that this unwarantable destruetion of Hawks and Buzarals affects adversely the condition of the birds with which our Scottish mountains are stocked-the number of wounded birds alone which smrvive the unprecedented amual slanghter thromgh which the lied Grouse is now ohliged to pass being an aroument sufficient to show that such merciful agents are wanted to prevent the spread of enfeebled life. In other sections of the animal kingdom epidemics similar to that affecting Grouse have been uoticed; and, so far as my own observations have enabled me to judge, I am disposed to regard these periodical outbreaks of discase as more or less associated with a derangement of Nature's laws. In almost every case where undue protection is given to eertain animals by the rigorous destruction of others, man's interference is followed, sooner or later, by evils of a graver nature than those which the protective measures were intended to cure; and until some more rational plan is tried for the restoration of the Red Grouse to its original vigour, no one can say what may be the final issue of the somewhat anomalous position in which, as a species, the bird is now undoubtedly placed."

I can fully indorse the general remarks of Mr. Gray respecting the inconvenience arising from the mudue protection afforded to certain species hy the rigorous destruction of others. Ntrange as it may appear, the keeper who supposes that he is zealously guarding the interests of his employer by ruthlessly destroying all rermin from the estate is in some instances committing an error. As an example in point, and one not mentioned by the writer above quoted, I may remark upon the destruction of the White $0 \mathrm{wl}$, which, injuring the game to a very small extent, confers much compensatory benefit in the destruction of the mice, rats, and weasels upon which it feeds. Our pretty Kestrel, ton, often suffers an ignominious fate without a reasonable excuse, its food generally consisting of moles, mice, lizards, frogs,s, and the larger insects. Considerable latitude must, howerer, be accorded to the keeper, who, with all his care and anxiety, is frequently nonplused by the continued loss of his young game, and that coming from a quarter little to be suspected. Some of the more intelligent of his class have, by constant watching, detected the Brown Owl habitually haunting the ricinity of his pens, and seizing, as occasion offered, two or three of his chicks. The Moorhen (Gallimla chloropms), too, stealthily threading its way through the grass, is no less to he dreaded, its presence among the coops not resulting solely in the abstraction of the scattered grain, but frequently in the death of a chick from a blow of its pointed bill, a considerahle portion of the victim being afterwards eaten. No one who has lived much on the Thames, or other localities frequented by this bird. can have failed to be struck by the fury and boldness with which it will attack a rat, a duck, or even so large a bird as a swan, if it approaches its nest.

"At the begimning of July." says H. J. Partridge, Esq., of Hockhan, Hall, near Thetford, in Norfolk, " the keeper having lost several Pheasants about three weeks old from a copse, and having set traj's 
in vain for winged and four-footed rermin, determined to lieep watch for the aggressor, when, after some time, a Moorhen was scen walking about near the copse. The keeper, supposing it only came to eat the young Pheasants' food, did not shoot it, until he saw the Moorhen strike a young Pheasant, which it killed immediately and devoured, except the leg-and wing-bones. The remains agreed exactly with eight found before. Perfect confidence may be placed in the correctness of this statement."-Zoologist, 1854, p. 4255.

For further evidence in proof of the correctness of these statements see my account of the Noorhen in the fourth volume.

In case what I have here and there said respecting the pugnacious and carnirorous propensities of the Moorhen should excite surprise, I may mention that they appear to be shared in common with all the other members of the group to which it belongs, from the delicately formed Rail to the most robust Porphyrio; and that they are all of a combative disposition is eridenced by possession of a sharp spur on the wing, short in some of the species, and prolonged in others.

The question has arisen whether, when we consider the present comparative scarcity of the Peregrine and other of their enemies, it will be really advisable to encourage the breeding of the marine or cliff birds, many persons being fearful that such a measure would lead to a great decrease in our edible fish, upon which they solely subsist. The daily quantity consumed by the Gannet and Cormorant, to say nothing of the Guillemots, Terms, \&e., is greatly beyond conception, thus showing that both care and judgement is necessary with regard to the new laws about to be enacted.

Had a measure been passed fifty years ago and penalties enforced for killing the Great Auk and the few remaining Bustards that then stalked orer our great plains, we should doubtless have still had these two fine birds gracing our islands; as it is, the former (Alca impenis or Gare Fowl) is wholly extirpated from the waters, not only of our own country, but of the universe ; the Bustard still holds its own on the Continent, whence now and then in the course of a few years one strays over the seas, and visits the haunts of those of its kind which formerly existed here; its permanent residence again among us, however, is rendered impossible by the gradual disappearance under cultivation of the vast plains and wolds over which it roamed, whereby they have been rendered incompatible with its existence. The Capercaillie, which probably died out from natural causes, was wholly absent for a hundred years, but owing to the replanting of pine-forests, the conditions farourable to its welfare are returning, and a fresh introduction has reinstated it. Other birds, such as the Crane, Spoonbill, Bitteru, Avocet, and the Ruff, which were once very common, have now, owing to the draining of our fens and marshes, no resting-places where they could dwell in peace and unmolested. Thus it will be seen that by man's industry in effecting improvements certain natural productions are greatly interfered with.

With regard to the exact enumeration of the birds frequenting the British Islands there must always be considerable difficulties, 
inasmuch as many persons would hesitate to include in our lists such species as hare from time to time strayed over from America, or others which we may reasonably suppose to have escaped from confinement. With these difficulties in riew I have restricted the additions to our list of native birds, with only a few exceptions, to those species pertaining to the fuma of the old World which, without constantly residing in our islands, have from time to time appeared therein, and whose visits oft repeated may ultimately entitle them to a permanent place in our lists. I may state with tolerable accuracy that the total number of our species is about three hundred and fifty.

If the supposed number of birds inhabiting the globe be about 10,000 , it must be admitted that the British Islands have their due proportion of them; of course it would be quite out of place to institute a comparison between our country, or eren the whole temperate region of either hemisphere, and the tropies, where bird-life is so redundant, in accordance with the profusion of fruits and insects upon which they mainly subsist.

It must be conceder by erery one who has paid attention to general ornithologs, that very considerable difficulties exist in the formation of a perfect scientific arrangement of the Birds of the British Islands, since these are but an appendage of a vast tract embracing the two continents of Europe and Asia, sections of the world assimilating in their bird-life, not only as regards genera, but in mans instances also with respect to species. Hence in our own lists there will be occasionally breaks, as it were, that would be filled up by forms which, while found not far distant from us, still have never beeu actually killed in our islands. Far wider gaps will of necessity occur through the absence of such genera as are peculiar to Australiathe Bower-, Lrre-, and Mound-raising birds, or of those which are confined exclusirely to the New World-Toucans, Trogons, Hummingbirds, \&c.

Man has frequently been induced to try his hand at the introduction of certain species the acquisition of which he has considered desirable; such attempts hare generally proved futile; Nature having adapted each for a certain locality, the climate and the condition of the country must be altered and rendered fit for the reception of either bird or quadruped before there is the slightest chance of their successful naturalization. Many persons have been desirous of establishing the North-American Prairie-hen (Cupidonia cupido) on our moors, and the Ortyx virginiums or American Partridge in our fields and coverts; but what good would be effected therehy? The Prairie-hen would but displace a better bird, the common Grouse; and the little Partridge would be no improvement upon our familiar species. There is no fear, howerer, that this will ever be accomplished; and the sooner such fallacies are ended the better. It would be far wiser were the efforts of our well-meaning patrons of acclimatization directed rather to that interchange of blood among the same species which is essential to the maintenance of a healthy stock. I am sure 
it is all-important with regard to our birds, particularly those that are stationary. It is well known that species which have lived long on an island without a sufficient interchange will diminish both in size and brilliancy of tints: and hence, perhaps, may be explained the smaller size and more subdued colouring of many of our birds, compared with continental examples. The Blackcock of Norway and Switzerland will be found to have the tone of its plumage more intensified than those inhabiting Scotland, the black being unmistakably of a darker hue, and the gloss of the futhers more resplendent. The Norwegian Ptarmigan, too, is of a purer white compared with our own bird, while its full summer dress is much darker. So, again, the Longtailed Tit (Hecisture cunduta) of Norway and Denmark differs in having a white head, while that of Great Britain has the crown and face dark or obscurely striped; and the Cole Tit (Pame ater) of Belgium in having the back srey, instead of the slight olive tint seen in British examples. T'o make such differences, howerer, grounds for specific distinction, as has in some cases been done, is in my opinion playing with science. That the drier and more rarified air of the Contiment, coupled with the more direct influence of the solar rays, contributes to cause these slight differences, seems to me highly probable; and I am strengthened in this riew by noting that among such groups as the T'rochilile, or Humming-birds of America, some of the richest and finest colours aro seen in species that frequent lofry situations.

Most of the Pheasants now spread over every county of the British islands are mongrels, brought about by the interbreeding of three kinds, and their progeny are but too often rickety and sickly creatures. Those of our sportsmen who have flushed a true Phasianus torquatus in England, or killed the same bird in China, its native country, must have been astonished at the quickness of its arrow-like flight, and the wildness of its actions.

The scientific naturalist of course repudiates all raricties such as the Pheasants allnded to, no two of which are alike in colour or markings, and whose promiscuous interbreeding can lead to no important result. We see this intercrossing carried to a still greater extent in our domesticated Pigeons and Fowls; but beyond the acquisition of certain variations in plumage, or of qualities rendering them more highly esteemed for the table, nothing of interest is attained.

Whilst on the subject of interbreeding I should wish to draw the attention of sportsmen to the advantages likely to accrue from the interbreeding of our Gronse with that of Norway (Tetrao saticeti). Ornithologists are questioning whether these are not one and the same species, and if the differences existing between the two may not be due to the influcuce of climate. Should such be the case (and I think it probable), then the introduction of the original stock would doubtless effect an improvement ' n the health and vigour of our birds. Prof. Raseh, of Christiania, believes the two so-called species to be identical, and is introducing our Grouse into his country partly to determine this point, and partly for the sake of the infusion of fresh 
blood; but more on this subject will be found in my account of the Red Grouse. As bearing upon their unity, I may mention that I made a journey to Norway for the sole purpose of studying the habits of Tetra saliceti, and observed that they differed in little or no respect from those of our Grouse, and that its crow was also similar.

Mr. Robert Gray remarks that, as a rule, all the Grouse from Lerris, Harris, North and South Uist, Barra, \&e. "may be said to be smaller and lighter in colour than those from moors on the mainland, especially the mountain-ranges of the north-east of Scotlind, which invariably yield in good seasons the largest and most beaultifully marked birds. In many districts the natire Grouse partake of the coloration of the ground in their markings: thus the finest and darkest birds are those frequenting rich heathy tracts; while on broken ground of a rocky character, such as may be seen in Wigtownshire, the grouse are either more or less mottled, or are altogether lighter in colour, and less in size and weight."

Before closing my remarks on the Tetrao saliceti and the English Grouse, it may be interesting to note that the extent of the southern range of the former, whether we look at it in Norway, Sweden, or Russia, is restricted to much about the same degree of southern latitude as that of our own bird in England and Wales, thus adding one more indirect. proof of their probable identity. On the other hand the Blackcock and Ptarmigan have a more extended sonthem range, both being found in Switzerland, if not in Northern Italy.

Although in a previous page I have discountenanced the introduction of new species, I may be here permitted to make an exeeption by adrocating the claims of the Gelinotte or Hazel-Gronse (Boncesc betulinu) to a trial of acclimatization in this country. Without putting forth this suggestion as original, I may state that having seen much of this excellent bird in Norway and other parts of Europe, and noticed that it there dwells in woods very similar to those which occur in Kent and other counties of England and ficotland, I see no reason why it should not be suecessfully naturalized; and I would suggest that those who are of the same opinion aud have the means of making the experiment should do so.

"It is to me a mystery," says Mr. Lloyd, in his "Game-birds and Wild Fowl of Sweden and Norway," "why the Hazel-IIen, which, from its English name, would almost scem to have been a former inhabitant of the British Isles, has not been naturalized with us, inasmuch as it is, of all game-birds, the most delicious, of consummate beanty, and of unconquerable hardihood, ' and adapted, moreorer,' according to Wr. George Chichester Oxenden, who has seen and shot these birds in most European countries, 'to every variety of cover, from pineforests to hazel-and oak-copses.' But it is not too late in the day for the Acclimatization Society to talse the Hazcl-Hen in hand; and if the localities were suitable for the purpose (and such there are, no doubt, in England and Sicotland), and the attempt were made witi from twenty to fifty braco of these birds, I see wo reason why it should not succeed." 
That the introduction of the Pheasant, the Guinea-fowl, and the Turkey has been to a cortain extent successful must be admitted; but it is to a certain extent only ; for it is beliered by competent authorities that the Pheasant if left to itself would die out in thirty years, and the Guinea-fowl and Turkey in a much shorter time. Nurses, feeders, and watchers are absolutely necessary for the preservation of these three birds, just as the safety and health of the Elands in Lord Hill's Park, at Hawkstone, are dependent upon the kceper who feeds and nightly shelters them during inclement seasons.

Had I not had ample experience on the subject of naturalization, I should not have prolonged these remarks; but having for the last forty years been a close observer of the denizens of the Gardens of the Zoological Society of London, a Society justly popular for its interest and usefulness, I have not failed to note that howerer high our hopes may have been raised respecting the probability of the successful introduction of many valuable species, nothing but bitter disappointment has been the result. Two or three instances will suffice. Soon after the arrival of the beautiful Mandarin Ducks they commenced laying, and hatehed out several elutches of young; it was therefore only natural to infer that this lovely denizen of the Celestial Empire would hereafter grace our ponds and lakes; but such has not been the case, and very sparingly indeed does the bird breed after the second or third year of its introduction. Three species of the equally beautiful Ceriornithes, or so-called Horned Pheasants, hare at one time or other also graced the gardens, and gare carly evidence that they would reproduce their kinds; and many of them did so; but, alas! the same result followed; for in a very few years all, both old and young, sickened and died. $\Lambda$ like fate attended the fine Crossoptilons: they laid frecly, and a numerous progeny were raised during the first two or three years; but they ultimately all perished; and thus these fine and rare members of the Phasianite, which formed unrivalled ornaments to the Gardens in 1870, were, in 1872 , not to be scen. Many other instances might be cited in support of this riew of the impossibility of naturalizing a foreign species. Nature, as a rule, places each species in the locality best adapted to it; and its removal to any other is pretty certain to end in failure. The attempts at introduction of these and other birds by such a society as the Zoological, howerer, have this good end-that they enable the public and the scientific ornithologist to view in a living state objects of which otherwise they could only inspect the dried skins, and, when they breed, to make themselves acquainted with the colour and markings of their eggs, the downy state of their young, and the changes of plumage they undergo until they attain that of the adult. Still it is to be regretted that their existence is not further prolonged.

Each season of the year possesses its peculiar attractions; but spring has especial claims upon our notice. The sun, awakened from his winter lethargy, ushers in this delightful season with his genial warmth; and all nature greets with joy the presage of coming summer, and its many pleasing and interesting associations. The 
smaller birds are now prompted to exercise their rocal powers, filling the woods and hedge-rows with their joyous harmony; and preparations for pairing forecast the breeding-season. The Grouse tribe resort to their "lek-stalles*", the Ruffs to their hillocks; the Rooks return to their ancestral elms, and the Daws to the nooks and crannies of the castellated tower.

It is at this particular season that birds assume their gayest colours, and oftentimes appear in accessory plumes. The Peacock now spreads his magnificent train to the greatest adrantage, the Ruffs display their curions neck-plumes, the Grebes their tippets. and the Egret its flowing back-feathers. In short, erery species is now arrajed in its newest and most showy dress. Pairing having. been accomplished, each species sets about the serious responsibilities implied in the propagation of its lind. Some, during this scason, delight to nest in company, as seen in our own familiar Rook, which will occups in immense numbers the lofty trees of many a noble arenue, returning, year after jear, for centuries, to the same spot. Such places, again, as Ailsa Craig, Handa, and Flamborough Head attract myriads of cliff-haunting species, which erince a similar tendency to reproduce in colonies. Few more wonderful sights can be seen during the month of June than the precipitous face of one of these places, say Handa. Viewed from the sea, there may be descried tier upon tier of Guillemots and Razor-bills, dre., almost jostling one another, from the manner in which they are closely packed. Each species constitutes a separate community, and strictly eonfines itself to its own ledges. The Cormorants and Gulls have also their selected situations. Far above all, in their curious rabbit-like burrows, in the sandy earth corering the summit, congregate those oddest of all birds, the Puffins. The din and noise of such an assemblage is indescribable, and, when a gun is fired, almost unendurable; while the circling, swooping flight of the countless myriads thus disturbed communicates the sensation of complete bewilderment. Usually among these great gatherings will breed a pair of some raptorial bird, such as the Peregrine, or more rarely the White-tailed Eagle, while in some of the more southern cliffs the Chough uestles, and adds its cackling cry to the unirersal hubbub. The Common Heron, again, is a bird nesting in communities, choosing, as a rule, large pine-woods, - wotable examples being the celebrated heronry on the property of Sir George Musgrave, Bart., at Eden Hall, in Cumberland, which comprises about one hundred nests, and that on the estate of W. Amhurst T. Amburst, Esq., at Didlington Park, in Norfolk. Other and most interesting colonies of birds are to be seen, such as those of the Black-headed Gulls, in various counties, particularly at Scoulton and other meres in Norfolk.

With respect to the receptacles for their eggs when laid, hirds offer

* Lek and lek-ställe are Norwegian terms, applied to localities "where affairs matrimonial are carried on." Wo find them frequently used by Mr. Lloyd in his 'Game-birds and Wild Fowl of Sweden and Norway,' when alluding to the courting assemblies of the Capercailie, Blackcock, Snipe, \&c. 
many interesting peculiarities. Some will content themselves with the bare ledge of a rock, the pyriform shape of their eggs being the only safe-guard against their filling over the precipice; others deposit their egrgs on a mass of sea-weed or in a floating nest composed of rotten aquatic plants, as is the case with the Grebes. Whero a more ambitions structure is erected, we find every degree of complication, from the loosely built platform of the Wood-Pigeon to the elegant lichen-crusted nest of the Long-tailed Tit. Each species shows in its nesting a most perfect adaptation to the exigences of the situation. Where, like the nest of the Sedge Warblers, it is swayed to and fro amidst the reeds by every passing wind, the deep purse-like shape of the interior is a safu provision against the eggs being blown out; under our eares the homely Martin plasters its nest of mud; the Goldcrest hangs its hammock-like cridle bencath the tip of a pendent fir bough; and in holes of trees and walls the Tits delight to construct their felted nests.

I should fatigue my readers and exceed the latitude allowed mo in this introduction, were I to dwell longer upon the situations affected by various species in their nidification or the wondrous forms shown in the construction of their homes; otherwise I might dilate upon the ingenuity displayed in the dome-like nests of the Magpie, in the approach to that shape seen in those of the common House-Sparrow when built in trees, or in the fish-bone floor of the Kingfisher's retreat; but all these will be found more fully dwelt upon in the descriptions attached to the representation of eich species in the body of the work; I may, however, remark in passing that the structural skill displayed by many of our birds is far surpassed by that of certain foreign species; and we are struck with astonishment when we gaze upon such nests as those of the Tailorbird, the Sociable Grosbeak, the Weaverbird, the Icteri or Hang-nests.

In writing upon subjects connected with ornithology I find the associations of my boyhoor ever flitting before me. Well can I recollect the dried body of the brightly coloured Kingfisher hanging from the cottager's ceiling, and supposed by its movements to point the rlirection of the wind *- $-\mathrm{n}$ superstition now, like many others, happily abandoned. We'l do I recollect also the particoloured strings of e'ggs with which I and my companions delighted to festoon the wails, and which were rigorously destroyed in our games, before the termination of the year, in order to ward off the ill-luck otherwise stuplosed to ensue. I can still remember with what intense admiration I was filled in gazing won the nest and lovely blue eggs of the common Hedge-Sparrow, and the pride I had in consigning them, when blown and thus bereft of half their beauty, to that string which was to hold so many of my subsequent findings. Coequally with the spreal of natural history generally, has adranced the interest felt in the collecting of eggs-so much so that eren amongst school-boys they now find their way into carefully appointed cabinets, in place

* "But how now stands the wind?

Into what corner peers my halcyon's bill?

Marlow's Jew of Maltc. 
of being used only as the plaything of an hour. The study of Oology at the present day may fairly claim an important place amongst the sciences; and, to speak more specially on the subject, I could name sereral men, whose studies have taken this direction, who follow their taste with such ardour that neither distance nor expense suffice to deter them. One of the most enthusiastic of these was the late Mr. John Wolley, who immured himself in the heart of Lapland for two or three winters for the sole purpose of being sufficiently early on the breeding-grounds to procure such rare egges as those of the Gyrfalcon, Pine-Grosbeak, Waxen Chatterer, and Smew. To enhance still further the interest attaching to the study of Oology, I have only to refer to the beautiful form, colour, and markings of most eggs, and to the difference in the number that are laid by various species. The Common Guillemot and the Razorbill lay but one, and that verylarge in comparison with the bird; on the other hand the Grouse will lay nearly a dozcn; the Swift lays invariably two, and the Swallow four, while some of our Tits deposit from twelve to fourteen. Those eggs which are white are frequently placed in dark situations; but this is by no means a coustant rule, since in the case of the Wood-Pigeon and Turtle-Dove the cgrgs are not only fully exposed to light, but owing to the slight structure of the nest, may be frequently descried through it. Their allies the Steck-Dove and Roek-Pigeon, howerer, lay theirs in the dark, as does also the Wryneck, all three having white egrgs. On the other hand the Nuthatch, Creencr, and many of the Tits, producing specliled eggs, deposit them in holes of trees and other places inaccessible to the light of day.

From the egg to the chick is a natural sequence; and here commences a stage in the life of birds which has been regarded by myself with more than ordinary interest. If any one feature in my illustrations to the 'Birds of Great Britain' has special claims to originality, it is the representation of the young or infantine state of many of the species; and this, I trust, will be duly appreciated by those who possess the work. In the imagination of most people young birds are blind, callow, helpless creatures, depending in erery way on the fostering care of their parents, and instinctively opening their gaping bills to receive the food assidnously brought to them. Such a helpless condition as this undoubtedly prevails amongst the young of nearly all, if not all, the Insessoricl birds ; but compare these with those of other forms, and what vast differences are seen! The tiny offspring of the Grebe, emerging from its bursting shell in all the vigour and activity of a fully organized being, is immediately capable of clambering, should danger approach, upon its mother's back, or of secking security and concealment by diving under a floating leaf. Who is not familiar with the Duckling, which, from birth, equals, if it does not surpass, its parents in the quickness of its movements, and in the skill with which it darts over the surface of the water in pursuit of flies or other insects? As a means to an end (that of continuing its existence unaided), the young Duck is as perfect as the old bird, though destitute of the power of flight, 
to be accorded to it hereaftor. What the webbed feet and swimmingcapabilities are to the immature birds above mentioned, the organs of flight are to the chick of the Gelinotte or Hazel-Hen, which, within a day of its exit from the shell, is endowed with such a development of its primaries and secondaries, that it can fly from branch to branch, or dart after its parents through the wood, with an ease and rapidity equal to that of any other little bird. At this early stage the Gelinotte appears all wings, and, from the dowu which alone covers its body, presents somewhat the appearance of a gigantic moth. The young of the Heron exhibit a very low degree of perfuetion; but those of the Crane, the Bustard, and the Plover are agile on exclusion. The colouring of the downy stage of young birds is, in many instances, very beautiful, and fantastic indeed in formexhibiting itself in stripings amongst the Grebes, yellow moss-like marblings amongst the true Plovers, paintings on the face of the Coot, and tortoiseshell blotches on the Black-headed Gull. This peculiar phase in bird-life exists but for a short period-six or eight days; a change then takes place, in the course of which the downy dress, with all its pretty markings, is thrown or, rather, pushed off by a succession of real feathers. In the Starling, among the Insessorial birds, it is exchanged for a uniform coat of brown, which, before the summer is over, is again transformed into a spangled dress of great beauty. In the Golden Plover the moss-like marbling is exchanged for a yellow speckled plumage; the Grebe loses its dorsal stripes, and assumes a silken white breast; the young Coot, deprived of its painted face, soon presents an approach to the colouriug of its parent; the grey middle dress of the young Heron gradually merges into that of the adult; and the newly hatched Falcons, which are blind, white-down-covered, sprawling creatures, pass through a variety of changes between their birth and the commencement of the seeond year of their existence, when they attain their perfect adult plumage, never again to be altered. Changes of a similar description also occur among the Owls. Many, if not most, birds, in fact, undergo a succession of alterations in their costume between birth and maturity ; but as there is no rule without an exception, so there are some birds which are not subject to any great change of this kind: for instance, the Kingfisher from the first is nearly as fine in colour as when adult, as are also the Roller, the Waxen Chatterer, the Tree-creeper, and the Nuthatch.

In the foregoing passages I have described some of the remarkable changes which birds undergo between youth and maturity; but however interesting and curious may be the details of their infantine states, their progress through middle life is not less so-while the culminating point, so far as costume is concerned, has not yet been reached; for, wonderful as are the phases through which they have progressed, these are as nothing compared with the assumption of the richer dress und colouring that obtains at the pairing-season. The transformations that take place in the Plorers and many other species at this period are indeed most remarkable, and, I believe, little 
known to any but ornithologists. The white breasts of the Golden and Grey Plovers now become of a jetty black, and the same part of the Godwits of a rusty red ; the Lesser Gulls assume hoods of bromn, and the Terns caps of glossy black, presenting a striking contrast to their coral-red feet ; the Divers doff their brown dress for a chequered one of black and white; the Sparrow acquires a black bill, the Chaffinch and the Hawfinch blue ones; and the whole are now decked for their summer duties, after the performance of which they again resume the garb of winter, and retain it until the following spring.

Of the myriads of created beings which adorn our globe, birds must necessarily rank highly in the estimation of man, and be to him at all times objects of the greatest interest, inasmuch as they not only contribute in a hundred ways to his delight, but many of them to his sustenance. The buoyant Eagle, soaring in aïrial evolutions towards the sun, elicits his admiration; and the rapid stoop of the Falcon excites his wouler. The Owl, which with noiseless flight crosses his path during its nocturnal prowlings, induces his surprise at the readiness with which it discerns the agile mouse and other small quadrupeds among the grass. If the fields attract him to roam in the day time, the Lark and the Corn-Bunting are his companions; and he hears the roice of the Yaffle, proclaiming the approach of rain. If in the woods he is induced to stroll, the coo of the Pigeon strikes his ear, or the tapping of the Woodpecker arrests his attention, the songs of the Thrush, the Ouzel, the Blackeap, and other sylvan birds, with the Nightingale at their head, afford food to his mind and sweet music to his ear; the Crows, the Rooks and the Darss attract his notice; and he does not fail to observe the difference in their cries, actions, and economies. In the neighbourhood of streams the bright meteorTike flash of the Kingfisher, the heary futter of the Moorhen, and the skimming flight of the Summer Snipe induce him to note how differently birds pass through the air, and to contrast the comparatirely slow morements of the latter with the sweeping flight of the Swift, which nearly outstrips the wind. On the shores of the ocean a tlood of new objects meet his gaze-the fairy-like Tern, the more robust Gulls, with Cormorants and many other aquatic species. In the marsh he hears the Snipe drum, the Bittern boom, and the plainly coloured Reed Warblers pour forth a succession of querulous sounds when intruded upon. While enjoying the invigorating air of the downs, though now deprired of the pleasure of seeing the stately Bustard, perchance his attention is arrested by the trippings of the Dottrel; the Stone-Plorer may rise at his feet, and wiug its way over the hill to a place of security; or the Wheatear and the Furze-Chat may attract his notice, the former by the whiteness of its rump, and the latter by being perched on the rery top of a furze-bush; and if it be autumn, the heary, flapping flight of the Pewit will show him that its structure is not so well adapted for passing through the air as that of the sharp-ivinged Golden Plover.

In studying the denizens of our inland waters other opportunities for drawing a comparison will present themselves; he will not fail 
to remark the wondrous principle of adaptation, which enables the frightened Grebe after its plunge to progress with the aid of its wings as rapidly beneath the surface as the Coot with drooping legs orer it. Instances almost without end of the delight which the study of birds affords might be cited; but I will now say a few words on their uses as articles of diet.

$\Lambda$ s a rule, birds are far less utilized in this country than on the Continent, where eren the smallest are eaten, the Robin, the Wryneck, and the Wren not exeepted, as a visit to the markets of Paris and Rome will testify, the sylvan Beceaficos and the Ortolans being specially regarded as bonnes bouches.

Among the water-birds, the Scoters and other diving ducks, being regarded as partly fish and partly fowl, are allowed to be eaten on fast days, and are therefore in great request; and $\mathbf{M r}$. Augustus Smith of 'Acilly tells me that the French sailors who land on those islands frequently ask his permission to kill Cormorants and Shags, considering them, as they do, the best of fowl. The Ganuet is largely caten in the northern parts of the lingdom, while the Fulmar not only forms the principal diet of the St.-Kildan, but its feathers constitute his bed, and its oil furnishes him with medicine and the means of light. The late Mr. Joln Maegillivray states that the eggs "are much esteemed by the natives, who gratify their partiality by robbing all the nests in the month of May, and apparently trust to the bird laying a second time ;" and, adds Mr. liobert Gray, "the young is ralued more than all the other tribes of birds taken together; it may be said to be their staff of life. The 12th of August, if a notable day on the moors, is more so on the rocks of St. Kilda; for it is the harrest of the people, who are aware that it will only last eight days; and therefore slecp itself is banished for this space, sceing that the millions that may be left on the eighth day after the 12th are sure to be off to their own fairy world for a season. The number killed in this one week may he from ciglteen to twenty thousand." In a valuable paper on the Solan Goose or Gannet by Dr. R. O. Cumningham, published in "The Ibis' for 1866 , it is stated, on the authority of the celebrated Harrey, that "the young, when they attain the magnitude of the domestic Goose, are sweet and fit for eating; but the fiesh of the old birds is hard, lean, and dry." And Ray in his 'Itineraries' mentions that "the young ones are esteemed a choice dish in Scotland. As the bird feeds unon mackrel and herring, the flesh of the joung smells and tastes strong of these fish."

At the present time, according to Dr. Cunningham, "from one to tro thousand of the young birds are killed annually for sale, and after being plucked obtain a price of from sixpence to a shilling each ; at one time they figured at the tables of the Scottish monarchs, and more recently were estcemed by the citizens of Edinburgh and other towns, being roasted and eaten as a relish bofore dinner. Now I believe their consumption is chiefly limited to the lower classes; and I have been informed on good authority that, after being parboiled and having had their legs cut off, they are sold in considerable numbers to the Irish peasants who come over to Scotland at harrest time." 
It is quite impossible to give an estimate of the numbers of wild Ducks and Geese that are yearly consumed in the three kingdoms; but that they are immense will be readily conceived when it is stated that from the rarious decoss, and from the Continent, hundreds, if not thousands, are weekly sent to the markets of the metropolis and other large towns, to which the professed wild-fowl shooter also transmits his quota of Wigeons, Pochards, and Brent Geese. The Common Pewit and the Golden Plover are largely consumed, as are also the Stints and other strand-loring birds. The supply of Snipes and Woodeocks is dependent in a great measure upon the nature of the season, as is also, to a certain extent, that of the Wood-Pigeon, the Partridge, the Grouse, the Pheasant and other game-birds. The Dottrel, which passes over our islands from south to north during the month of May, is subjected to a large anmual toll, and, with the imported and fattened Quail and the Ortolans, forms delicate viands for the tables of the wealthy and of the epicures who require such whets for their appetites, and who can afford their purchase. Besides the species abore mentioned, many other kinds, and even the egrgs of several, are diligently sought for; those of the Lapwing, Blackheaded Gulls, and Guillemots, especially the former, being in great request. These remarks may appear trite, but they serve to show that many of our birds are extensively utilized.

Much has been written upon the classification, gencral structure, power of flight, and senses of birds; but were I to go into detail on these matters I should only be reproducing what has been so ably treated by such men as Macgillirray, Owen, Jerdon, Flower, Huxley, Parker, and others. I cannot, however, conclude the present introduction without touching lightly on some of these points.

Most writers on Natural History have placed the class Ares immediately above the Reptiles and below the Mammals, from either of which they are clearly separated by the distinctive characteristics shown in their general form, habits, feathered corering, and porrers of flight. It is in regard to some of these that I would now wish to say a few words. All those who have studied the anatomy of birds, even but cursorily, must have become specially aware of the wonderful adaptation shown by nature in fashioning the skeleton so as to enable the creature to support itself in the air with the least possible excrtion, and propel its body with rarying degrees of swiftness through that element; they will have noticed that this power of flight is aided to a considerable extent by the fact of the bones beine hollow, and their cavities communicating for the most part with the cells of the lungs - a provision ensuring the maximum of strength with the minimum of weight.

The wings of birds modify in various ways the velocity with which they are capable of cleaving the air. Some, like the LandRail and the Bittern, with rounded wings, evince considerable reluctancy to quit the ground, and, when they do so, merely fly to a short distance; others, such as the Auks and Penguins, have, indeed, but the rudiments of those organs; while others, again, have thcir wings and pectoral muscles developed to such an extent that extraordinary 
rates of relocity and distances traversed have been recorded. 'Thus Mrr. Charles Boner states, in his 'Forest Creatures,' that the flight of the Eagle is sixty feet per second, being at the rate of somewhat more than forty miles per hour; and my friend W. White Cooper mentions, in his '/oological Notes and Anecdotes,' that "the flight of a Hawk is calculated at one hundred and fifty miles an hour; and the anecdote of the Falcon belonging to Henry IV. of France, which flew, in one day, from Fontainebleau to Malta, a distance of thirteen hundred and fifty miles, is well authenticated."

Mr. Harting, in his interesting 'Ornithology of Shakespeare,' mentions that the flight of the Common Swallow (Himudo rustica) has been computed to be at the rate of ninety miles an hour. If this be a just computation, that of the Alpine Swift must be twice as great; but these are as nothing when compared with the velocity of the Frigate-bird (Tachypetes aquilus), which, says Audubon, "is possessed of a power of flight I conceive superior to that of perhaps any other bird. However swiftly the Cayenne Tern, the smaller Gulls, or the Jager move on the wing, it seems a matter of mere sport to it to overtake any of them."

"There are two facts observable in all birds of great and longsustained powers of flight," remarlis the Duke of Argyll, in his admirable 'Reign of Law:' " the first is that they are always provided with wings which are rather long than broad, and sometimes extremely narrow in proportion to their length; the second is that the wings are always sharply pointed at the ends. Let us look at the mechanical laws which absolutely require this structure for the purpose of powerful flight, and to meet which it has accordingly been derised and provided. One law appealed to in making wings rathor long than broad is simply the law of leverage ..... and a long wing is nothing but a long lever. The mechanical principle or law, as is well known, is this:- that a very small amount of motion (or motion through a very small space) at the short end of a lever, produces a great amount of motion (through a long space) at the opposite or longer end. This action requires, indeed, a very intense force to be applied at the shorter end; but it applies that force with immense advantage for the purpose in riew, because the motion which is transmitted to the end of a long wing is a motion acting at that point through a long space, and is therefore equivalent to a very heavy weight lifted through a short space at the end which is attached to the body of the bird. Now, this is precisely what is required for the purpose of flight." The preceding extract is sufficient for my present purpose; but my readers will find many other interesting remarks, on the laws affecting and governing the flight of birds, in the work above mentioned, to which I would earnestly direct their attention.

Birds, like other animals, are endowed with the usual senses; but these vary in degree of perfection in accordance with the variety in their habits. That that of sight is very highly developed is amply testified in the Fiestrel, whose ejes must be almost telescopic to cnable it to see an insect or a mouse on the ground from the great 
elevation at which it usually hovers; the familiar Robin, who discovers the wriggling worm at a distance of many yards, must also be endowed with acute powers of vision; nor can it be less perfect in the Shrike, who sallies fourth from his chosen branch to secure with unerring aim the passing fly or beetle. The Vulture, provided with organs of equal if not even greater power, descries from an enormous distance a dying camel, a stranded sheep or any other earthly creature which has met with misfortune, and by his peculiar motions gives the cue to others of its kind from still greater distances and various points of the compass; for "wheresoever the carcase is, there will the Eagles be gathered together."

The sense of smell is most acute in the Anatide or Duck tribe, but according to my experience seems to be entirely wanting in the Raptores, Vultures, Eagles, \&c.

That of hearing would appear to be most perfect in the Owls, as testified by their highly dereloped auditory conch; at the same time it is by no means wanting in many other families of birds.

Neither can the sense of feeling be absent from the probing bill of the Woodeock and the members of the Scolopacidce generally.

Should any of my readers wish to enrich their knowledge in this direction, I must refer them to the works of the writers mentioned above. In 'The Birds of Great Britain' my chief aim has been to give a faithful representation of the various species, and to record, in addition to the notes of others, such observations as my lengthened study in this branch of science has enabled me to make.

The following arrangement will give a general riew of "The Birds of Great Britain,' with some additional information respecting them obtained during the progress of the work, and notices of those species which have occurred in the British Islands but which are not, in my opinion, entitled to a place in our fauni and consequently have not been figured.

\section{ORDER RAPTORES.}

\section{Family VULTURIDÆ.}

The Vultures, a family of birds whose proper home is the warmer countries of the world, are but feebly represented in the British Islands, where, indeed, the appearance of the two species which have occurred therein must be regarded as purely accidental, our islands being fortunately exempt from those visitations which render the presence of these useful scarengers a matter of great importance. The family comprises abont twenty-four species, divided among ten or twelre genera, the greater part of which inhabit Eastern Europe, Africa, and India ; the remainder frequent America, and extend their range from the United States to Chile. 
Genus Neopinton.

1. Neopirron perchopterts . . . . . . . . Vol, I. Pl. I. Egrptian Vúliture.

We have rery positive evidence that this bird has been killed in Somersetshire and lissex, of which occurrences the particulars will be found in my account of the species.

\section{Grips FULUUS.}

\section{Genus Gros.}

\section{Griffon Vulture.}

This bird has still less claim to a place in the British Fauna than the Egyptian Vulture, I have therefore not given a plate of it, notwithstanding that its occurrence has been recorded by Thompson, and that Yarrell has figured it from a specimen " caught by a youth on the rocks near Cork harbour in the spring of 1843. The bird was full grown ; the plumage perfect, without any of the appearances consequent on confinement; it was very wild and savage, and was in perfect health."

This Vulture is of large size and proportionate strength, possesses great sustaining powers of flight, and enjoys a widely extended geographical range, being found in Germany, France, on the Pyrenees, in Spain. It also occurs in the Grecian archipelago, Candia, Egypt and other parts of North Africa; and Dr. Jerdon states that it also inhabits Western Asia and the Himalaya Mountains. It makes a large nest, 3 or 4 feet in diametcr, on rocks and high trees, and lays two, or sometimes three, elongated white eggs nearly as large as those of a Goose.

\section{Family FALCONID AE.}

\section{Subfamily AQUILIN E.}

Eagles are very generally spread over the temperate and warmer portions of the globe. Four species frequent the British Islandsnamely, two of the genus Aquila, one of Haliaëtus, and a Fundion.

\section{Genus AQUIIA.}

3. AnUIIA chrtsä̈tos . . . . . . . . . Vol. I. PI. II.

Golden Elgle.

$\Lambda$ bird of the northern portion of Britain, where it still breeds, as it formerly did in Derbyshire, as it is also said to have done in North Wales. The young are apt to wander southwards; and hence we occasionally see immature cxamples in England, but seldom adults.

4. Aquila natia . . . . . . . . . Vol. I. Pl. III.

Spotted Eagle.

The native home of this bird is the eastern portions of Europe, 
North Africa, and India. To England its visits are purely acceidental; jet it has been killed therein six or seren times-namely, once in Hampshire, twice in Cornwall, and thrice in Irelaud.

When mentioning in my account of this species that the second Cornish example, killed near Carnanton, is now in the Truro $\mathrm{Su}$ seum, I ought to have added " to which institution it was presented by E. Brydges Willyams, Esq."-an omission which I now rectify.

\section{Genus Haliaterus.}

\section{Haltak̈tus atmtetlea . . . . . . . Vol. I. Pl. IV. SEL-EAgLe.}

Inhabits Greenland, Europe, and North Africa. More maritime in its habits than the Golden Eagle. Breeds in the north. Feeds on fish and garbage of any kind thrown up by the sea.

Since my account of the Sea-Eagle was printed, Captain Elwes has published, in 'The Ibis' for 1869, an interesting paper on the "Bird-Stations of the Outer Hebrides."

Speaking of the Spiant Isles, " a small group lying in the Minch, about six miles from the coast of Lerris," he says: "There is i celebrated eyry of the White-tailed Eagle (Halicëtus albicilla) here, which has been used from time immemorial and is mentioned by Martin, who wrote nearly two hundred jears ago. I think it is as perfectly inaccessible as any nest can be, owing to the way in which the rock overhangs, and, if the birds are not destroyed, will remain in use for centuries."

\section{Genus Paxdior.}

6. Pandion maliatetes . . . . . . . . Vol. I. Pl. V.

\section{Osprey.}

Formerly common in Scotland, where on most of the ruined castles in the neighbourhood, and on the islands in the lochs, its eyry might have been found; now it has become scarce, and, unless it be protected, will soon be extirpated. If, as has heen supposed, there is but one species of this form, then it may be said to be almost unirersally distributed over the other parts of the Old World, as it also is in the greater part of the New. Lives almost wholly on fish. Is a summer risitant, arriving at its breeding-places in the spring, and departs southward in autumn.

\section{Subfamily BUTEONIN.E.}

Buzzards are found in nearly every country of the globe. The fauna of Europe comprises three or four species, all of which have been killed in Britain ; but of these one has but slender claims to be enumerated among the birds of our islands. 
Genus Bưteo.

\section{BUTEO VULGaris}

Common Buzzard.

Formerly very common in many of our counties; it still breeds in some of them, particularly in certain parts of Kent.

8. Buteo desertortui . . . . . . . Vol. I. Pl. VII.

Falco desertorum, Daud. Traité d'Orn. tom. ii. p. 162.

___ cirtensis, Levaill.

— vulpinus, Licht.

_apensis, part., Sehleg.

_ tachardus, Bree, Birds of Eur. vol. i. p. 97. anceps, Brehm.

Mr. J. Clarke Hawkshaw has favoured me with the skin of a Buzzard which, he tells me, was killed at Everley, in Wiltshire, in September 186t. After having made a careful examination of the specimen, Mr. J. H. Gurney assures me that it is an example of the species to which the abore names hare been assigned by the various authors mentioned, that of desertorum having the precedence. The countries frequented by it are Algeria, Mogador, European Turkey, the mouths of the Volga, Syria, India, and Ceylon.

Mr. Gurney considers that there is no specific difference between this bird and that which is named in collections Buteo cirtensis. He came to this conclusion after examining specimens from Mogador, Tangiers, Erzeroum, and the mouths of the Volga. It is included by Schlegel in his 'Fauna Japonica;' so that it has a very wide range.

"The appearance of this bird when alive," says Mr. Gurney, " is less heavy and more elegant than that of $B$. vulyaris. My living specimen, which was dull-brown when I bought it, has moulted into a rich rufous plumage; and one that was alive in the Zoological Gardens a few years since, underwent a similar change." According to M. Favier, it nests among the rocks, and the male takes its turn in sitting. The egg has a strong resemblance to that of the Black Kite, but is a little more pointed, and the ground-colour a cream-white, that of the former having a greenish tinge.

Mr. Gurney states that "the cere, tarsi, and feet of this Buzzard are lemon-ycllow; the irides are sometimes light-hazel, and at others yellow, probably assuming the latter colour as the bird advances in age; a similar variation, howerer, which exists in the irides of the Common Buzzard is not always referable to age, as I have ascertained by experience."

\section{Buteo hineatus.}

Red-shouldered Buzzard.

It becomes necessary to notice this species, a single example having been shot at Kingussie, in $A$ berdeenshire, on the 26th of 
February, 1863. It is now in the collection of $\mathrm{Mr}$. Newcombe, of Feltwell Hall, Brandon, Norfolk. As this is a strictly NorthAmerican species, I do not consider it necessary to figure it : but such of my readers as may lesire to know its history can refer to the writings of Wilson, Audubon, and other authors on American birds.

\section{Genus Archibuteo.}

10. Archibuteo lagopus . . . . . . Vol. I. Pl. VIII. ROUGII-LEGGED BUZZARD.

Arrives in the British Islands in autumn, occasionally in considerable numbers, when moving in migratory flocks. Its nest is stated to have been once found near Hackness, in Yorkshire, and also in the neighbourhood of Banff (vide 'Ibis,' 1865, p. 12).

\section{Genus Pernis.}

Of this form there are two rery distinct species-one, the $P$. apivorus, inhabiting Europe, and the other the P. cristutus of India. The natural food of both is honey, bees and wasps, aud their larvæ.

11. Pernis apivorus . . . . . . . . Vol. I. Pl. IX. Honey-Buzzard.

A summer visitant to us and to Central Europe, which, after breeding, migrates southward to pass the winter.

\section{Subfamily ASTURIN E.}

Genus Astur.

Of this form two species have been regarded as pertaining to the British fauna-namely, the Astur prelumbarins of Europe, and the $A$. atricapillus of America. In the present work only the former has been figured.

12. Astur patumbarides . . . . . . . Vol. I. Pl. X. Gosinawr.

Very generally dispersed over Europe, North Africa, India, and China ; occasionally killed in Scotland, where it sometimes breeds.

13. Astur atricapilius.

American Goshawk.

This American wanderer has certainly been killed at least three times in the British Islands-once in Scotland and twice in Ireland. Respecting the first of these examples, Mr. R. Gray, in his recently published 'Birds of the West of Scotland,' says :-

"In May 1869, when visiting the town of Brechin, in Forfarshire, 
I was fortunate in finding a very handsome specimen of this Goshawk in the hands of a bird-stuffer there, who had obtained it a short time previously from a keeper in Perthshire, along with a number of Snow-Buntings and other birds shot by him on the flanks of Shechallion, and all recently skinned."

The following notes respecting the sccond example were published by Sir Victor A. Brooke in 'The Ibis' for 1870. "I have the pleasure of informing you of the occurrence in Ireland of Astur atrictepillus, an example of which was shot in the Galtee Mountains in February last, and was at first believed to be a common Goshawk (A. palembarius); but having since had the opportunity of examining some specimens of that species in Lord Lilford's collection, I immediately detected the difference between them and the Galtee bird. Upon returning to Ireland, with the kind permission of Dr. Carte I compared it with a specimen of A. atricapillus in the Dublin Socioty's collection, and cleared up any doubt that remained on my mind, the closely set transrerse bars, the longitudinal streaks (stronger and bolder than in the European species), the general dusky appearance of the breast, and the dark slate-blue head, removing all question on the subject. The bird was a mature female, and weighed 3lb. 7oz.; the ovary was somewhat enlarged; and the stomach eontained the remains of a rabbit." Of the third example, all that has been recorded is that it was shot shortly after the above, near Parsonstown, King's County, and was also a female.

A certain amount of interest attaches to the occurrence of these Goshawlis, inasmuch as it tends to show how frequently American birds cross the Atlantic to our shores; but if all such visitants wero to be figured, how greatly extended would be the "Birds of Great Britain.'

Subfamily ACCTPITRIN X.

\section{Genus Acciprter.}

Of this genus only one species frequents the British Islands; but several others are found in Africa, India, China, North and South America. The whole of them are active dashing birds, often flying near the ground and suddenly surprising the smaller insessorial species, upon which they principally prey. The sexes differ considerably in size, the males being much smaller than the females. A character by which they are at once distinguished from the Asturine consists in the great length of their middle toes.

14. Accipiter nisus . . . . . . . Vol. I. Pl. XI.

Sparrow-Hawt.

A common, stationars species, brecling in all our counties. 


\section{Subfamily FALCONINAE.}

\section{Genus Fìco.}

The members of this genus are preeminently bold, courageous, and sanguinary, many of them, especially the Gyr Falcons and Peregrines, not hesitating to attack in the air birds much larger than themselres; and when trained for hawking, as they have been from time immemorial, their courage and daring is so much enhanced that they will engage with birds of even larger size than they do in their wild state. Structurally they are better adapted for a quick and arrowlike flight than any other of the Raptores.

One or other of the numerous species of this group inhabit nearly every portion of the globe. The Gyr Falcon and its immediate allies are almost solely confined to the high northern regions, whence they migrate during autumn and winter towards the equator, but never across it.

The Peregrines are much more generally dispersed than the Gyr Falcons, the various species frequenting most countries both north and south; thus the form exists in Europe, Asia, and Australia, in Africa also from the Atlas range to the Cape of Good Hope, and in America from the latitude of Hudson's Bay to Terra del Fuego. The smaller Faleons, such as the Hobby and Merlin, are also more or less represented in each country, but generally, although not exclusively, are of different species.

\section{Fatco islandes}

\section{ICELAND Falcon.}

The subject of the great northern Falcons will be found so fully treated of in the body of the work that it would be mere tautology to say more here than that this bird is, as its name implies, a native of Iceland, and, but more sparingly, of Greenland. It is also said to be found in Hudson's Bay and other of the extreme northern parts of America. Occasionally adults, but more frequently young birds of the year, wander as far south as the British Islands.

\section{Falco islandes . . . . . . . Vol. I. Pl. XII. ICELAND FALCON (Young).}

Appears to be darkly coloured from the nest, but never so deep in tint as that of the true Gyr Falcon.

17. Falco candicans Vol. I. Pl. XIII. Greenland Falcor.

This species inhabits the icy regions of Greeniand, Hudson's Bay, and other parts of Aretic America, and is less frequently seen in the British Islands in the adult state than the $F$. islendus, from which it 
is distinguished by the extreme whiteness of its plumage, and by the young being lightly coloured from the nest.

\section{8, Falco candicans . . . . . . . Vol. I. Pl. XIV. \\ Greenland Falcon (dark race).}

My plate represents a supposed dark race of the preceding species; but as the strongly defined marks on the back vary considerably in different individuals, and the tail-feathers differ still more so, some being wholly white, others barred, and others, again, having irregular dark markings, I am induced to regard these darkly marked birds as the result of a cross between $F$. islandus and $F$. candicans. The joung appear to be lightly coloured from the nest; but a considerable difference takes place at the first moult, when the feathers of the back are ornamented with long and broad blotches, offering a strong contrast to the narrow, lunate cross markings of the old bird. I have been induced to gire two figures of these unusually marked birds.

\section{Falco candicans . . . . . . . . Vol. I. Pl. XV.}

Greenland Falcon (dark race, young).

Lord Cawdor's bird, now in the British Museum, from which my figure of the Gyr Falcon in the 'Birds of Europe', and Mr. Yarrell's in his 'British Birds,' were taken, is a young specimen of this race; and it is in this stage that most of the individuals are found with us.

20. Falco grrfalco . . . . . . . . Vol. I. PI. XVI.

Norwegian, or Grr Falcon.

The true Gyr Falcon of Norway, Sweden, Finland, and Western Russia is a smaller bird than the three preceding; and both the adult and young are darker in colour. As yet, it has not been found in the British Islands, although its native country is so near at hand. The plate has been given to show the differences which exist among these northern Falcons, to which Professor Kaup has applied the separate generic appellation of Hierofalco.

\section{Falco peregrinus}

Vol. I. Pl. XVII.

\section{Peregrine Falcon.}

Besides Great Britain, the Peregrine frequents Greenland, Iceland, the whole of Europe, North Africa, India, and China.

The following note, illustrative of one of the habits of this bird. kindly communicated to me by the Duke of Argyll, will prove of interest. It is dated from Inverary, June 4, 1868. "I find we are rich this year in nests of the Falconides:-two of the Peregrine; two of the Hen-Harrier, and a third, the spot not yet discovered; and one of the Mferlin. One of my keepers, who is, I think, a reliable man, tells me that the day before yesterday, when he was watching one of the Peregrines' nests, he saw the male rome from across Loch Frne 
with a bird in his talons. When he eried, the hen bird came out of the precipice and joined him in the air, and took from the male the bird he was carrying. This must have been a pretty sight."

22. Falco subbutfo . . . . . . . Vol. I. Pl. XVili. Новву.

A summer bird in our islands, where it breeds in woods, either in the forsaken nest of a Crow or in one which it builds for itself. I hare received Hobbies from other countries besides Britain and the continent of Europe, viz. India, China, and Africa, but not from America, where indeed, it is not found. This bird and some others of the same form have been deemed sufficiently distinct from the other Falcons to constitute it the type of a separate genus; by those authors, therefore. who adopt minute divisious of genera, it is termed Hypotriorchis subbutco, instead of Falco subbuteo. It is less bold and sanguinary than the Peregrine or the Merlin, feeds on insects to a considerable extent, particularly Chaffers, and consequently is somewhat crepuscular in its habits, such large insects being principally obtainable as they flit round the tops of great trees after sunset.

23. Falco EAStLon

Vol. I. Pl. XIX.

\section{MERLIN.}

This bird has also been removed by Professor Kaup from the genus Falco into that of Esulon, a division which, being a very natural one, the scientific ornithologist will not repudiate; but in a work on our native birds these minute dirisions are scarcely admissible, since the finding of so many of their old friends under new appellations could scarcely be otherwise than distasteful to my readers. In many instances where I have departed from the practice of the older naturalists, I hare been not lightly censured for the innoration; but the time will come when the generic appellation bestowed upon each distinct form will be more generally adopted.

The Merlin of the British Islands is by no means the only representative of the genus Esalon; for there are seceral rery distinct species in other countries, the names of which would he given were I writing a work on general ornithology instead of one on the birds of a limited area.

The $F$. asalon is a resident species, and very generally dispersed over the three kingdoms.

\section{Genus Errthropus.}

At least two species of this elegant form are known. Of these, one, E. vespertinus, is a native of South and South-eastern Europe, but occasionally wanders into Britain; the other, E. amurensis, is found on the Amur, in Nepaul, and over the greater part of Southeastern Africa. In disposition these birds are less sanguinary than the true Falcons: and their food consists principally of insects and their larra. 
24. Erytiropus vespertinus

Vol. I. P1. XX.

\section{Orange-legged Hobby.}

Although truly but an accidental visitor, at least thirty specimens have from time to time been killed in the British Islands, the greater number in England-Ireland and Scotland contributing only one each.

\section{Genus Tinnunculus.}

The birds trivially termed Kestrels comprise many species which are very generally dispersed over the Old World, Australia not excepted. In the New thes are less numerous; and those that are thero found have been formed by Professor Kaup into a distinct genus, that of Precilornis.

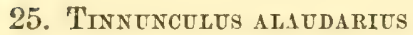

Vol. I. Pl. XXI.

\section{Kestrel.}

The "Windhover," as this bird is also termed, is so well known to every one who visits the country and "has eyes to see, and a mind to observe," that any special comment respecting it is unnecessary. The whole of Britain, the continent of Europe, Africa, India, and China are also frequented by it. Its food is much varied; for it eats mice, insects, mollusks, fish occasionally, and the young of most of the field-loving birds which nest on the ground, and, when opportunity offers, does not object to the joung of the Partridge and Quail. Such propensities, however, are in my opinion but a trifling counterpoise to the usefulness of this elegant bird; in fact it deserves protection instead of that extermination which will be its fate if a more fricndly feeling than at present exists cannot be created in its favour.

\section{Tinnunculus cenchris.}

\section{Lesser Kestrel.}

In June 1868, the Museum of the Yorkshire Philosophical Society was "fortumate enough to obtain a fine specimen, killed within a few miles of York, of a species of Falcon, the occurrence of which in this country has, I believe, never before been authentically recorded, namely the Little Kestrel of South-eastern Europe, (Tinnunculus cenchis, Naum.). The specimen, which is a mature, but apparently not an old male, was presented to the Museum by Mr. John Harrison, of Wilstrop Hall, near Green Hammerton, who shot it upon his farm at that place, after having observed it for some little time flying about. The date, he thinks, was about the middle of last November; but of this he took no note, as he at first thought the bird was merely a small and curious variety of the common Kestrel. It, howerer, presents all the distinctive characters of Tinnunculus cenchris, among which the yellowish-white claws may be mentioned as affording an easy moans of identifying the bird."

This bird has been forwarded by the authorities of the Museum 
for my inspection; and I find it to be, as represented, an example of the ahore species. I have not, however, figured this bird; it would be desirable to see other examples.

\section{Tinnunculus sparverius.}

American Kestrel.

A specimen of this bird, killed in Yorkshiro, is now in the possession of the Rev. C. Hudson, of Trowell Rectory, near Nottingham, who states that it has heen in his possession for about twelro years, and that he purchased it from a joiner named Brown, formerly living at Thorpe Hall, who was an enthusiastic collector of birds, and in the habit of preparing them for people in that neighbourhood. Brown's account of the bird, which he denominated the "American Falcon," was that it was shot between Bridlington and Bridlington Quay, one Sundity morning, by a man who sold it to him for eighteen pence. Through the kindness of Mr. F. J. S. Foljambe, Mr. IIudson kindly sent up his bird for my inspection, when I found it to be a very fine adult male of the American Kestrel, and not, as supposed, a second example of the $T$. cenchris.

\section{Subfamily MLVIN $\mathrm{A}$.}

\section{Genus Milvos.}

The true Kites, or the members of this genus as now restricted, are birds of the Old World, over which they are so generally distributed that, with the exception of New Zealand and Polynesia, one or other of the few species known are to be found in every part of it. Their disposition is less eruel than that of the true Falcons; and they feed principally on garbage; they are consequently useful seavengers, and, moreover, arrant thieres.

28. Milves regalis

Vol. I. Pl. XXII.

Kite or GLEad.

The common Kite of England, which in Shakspeare's time might probably be hourly seen soaring over the metropolis, is now, thanks to the exterminating hand of man, rarely to be seen in any part of the country. If a solitary pair should occasionally be met with, they should be hailed with reverence as being almost the sole remnant of a departed race, so far as our islands are concerned; for in Central and Eastern Europe, Asia Minor, and North Africa the species still exists. The Kites build large, grotesque, untidy nests of moss, wool, rags, and rubbish of every description; and when our species was plentiful, it must have kept the housewife on the alert for her frills and furbelows hung out to dry on the village hedge, fully justifying Shakspeare's line:-

"When the Kite builds look to lesser linen."

Inhabits Europe generally, Asia Minor, and North Africa. 
29. Mitudus mGrars .

Vol. I. Pl. XXIII.

BLACK KITE.

I have mentioned above the approximate extermination of the English Kite; and I may now state that, should such unhappily be the ultimate result, it seems likely that its place would be supplied by another species, the Mitures migrans, which would seem to show some indication of an intention to come among us, at least in one instance, as will be seen on reference to my plate of the species, which was taken from a specimen killed at Newcastle-on-Tyne.

Inhabits Central Europe, Siberia, Palestine, Africa, and Australia, in which latter country it is only an accidental visitor.

\section{Genus Nauclerus.}

The single species of this form is remarkably different from all the other Kites. Its more slender structure, lengthened wings, and long forked tail indicate that it possesses vast powers of flight, and that it would experience but little diffieulty in making a transit from its native country to even very distant shores, when cireumstances force it to leare its 0 wn.

\section{Natclerós furdatus.}

\section{Swallow-tailed Kite.}

This bird is so strictly American that I have not given a figure of it, notwithstanding it has been lilled at least five times in our islands, the earliest of these occurrences having been at Ballachulish, in Argyleshire, in 1772-since which others have taken place at Wensleydale, at Farnham, in Cumberland, and on the Mersey.

\section{Subfamily CIRCIN E.}

The Harriers, comprising numerous species, are so widely dispersed over the face of the globe as to warrant the use of the term universal with reference to their distribution. In each of the five great divisions of the globe one or other of the serenteen known species are to be found. In Europe there are four, three of which inhabit and breed in Britain. In habits and economy they do not resemble the Falcons, the Buzzards, or the Kites, but assimilate somewhat to the Strigidie, or Owls. Their actions, indeed, are peculiar to themselves; and their great flapping wings render them conspicuous objects when flying over a marsh or the sunny side of a moor, with keenly searching eyes, in pursuit of their food, which varies with the nature of the locality. If in the fen, reptiles, from the snake to the newt, are captured and caten, as are frogs and inserts; at the breeding-season young snipes, Moorhens, or other nestlings are fortunate if they escape their serutinizing eyes. They mainly nest on the ground, and lay four or five white eggs. Their flight is somewhat laboured and flapping. 
Ornithologists have divided the Harriers into five different genera; and even the three which inhabit Britain have each received a separate generic title, a procedure which may seem superfluous to some persons; but before placing his reto upon it each objector should have all the known species before him, when he would perceire that the great Marsh Harrier, with its brown plumage, differs considerably from the slender ash-coloured bird with its barred tail, and both from the uniformly coloured and stonter built He11-Harrier. knowing how strong the feeling is against the multiplication of generic terms, I have in this work retained them all in the genus Circus.

31. Circus ærequlvosus. . . . Vol. I. Pls. XXIV. \& XXV.

\section{Marsh Harrier.}

The draining operations which have been carried on of late years in various parts of the country have rendered many of the districts formerly adapted for the well-being of this and many other species no longer tenable by them; and from the great antipathy to this bird exhibited by every land-owner and game-keeper, it is now becoming scarce in this country; but in Holland and other low countries of Europe, Africa, India, and China it still holds its own. The plumage of the yearling and adult birds differs so greatly that I have been induced to gire two plates in illustration of these peculiar phases in their history.

\section{Circus cyaneus}

Vol. I. Pl. XXVI.

\section{HEN-HarRIER.}

Formerly much more numerous than at present, the all-destroying hand of man being directed towards its extermination; but it still exists in its nsual numbers in Scotland, where, Mr. Robert Gray states, it is very common "on all the islands of the Outer Hebrides group, and also throughout the immer islands, Skye, MIull, Islay, Jura, \&c., where it is known by the Gaelic name of Clamhan luch, signifying mouse-hawk," and alds that he has "seen twelve or fourteen specimens in one day on Benbecula and North List, where its huntinggrounds are of a similar nature."

The following note on the nesting of this species, from the pen of the Duke of Argyll, will be found of interest. Writing to me respecting some nests of two or three species of Falconidce observed by him at Inverary early in June 1868, his Grace says:—-"The Harrier's nest is on the face of a steep bank covered with long heather, and falling into a stream of considerable size. The nest itself is placed on a little bare shelf or ledge of sphagmem moss, and with none of the heather bending over or concealing it ; but the nature of the ground is such that it is not risible from the opposite bank of the stream; and on its own side the face is so steep that it would not be seen unless one were to come a fer feet abore it; but to birds flying over, the nest must be a conspicuous object. It contained six eggs, pure white, but with a slightly bluish tinge, which, I am told, is 
deepor when first laid. 'The nest was composed of dried twigs and stalks of heather as a foundation, and very nicely lined with straw, composed of dried 'sprits' (or' a kind of rush) and one or two bits of dried fern. The straws were nicely laid and bent round, so as to take the shape of the nest. The bulk of the whole was small; but the cup was decided though shallow.

"The hen rose from the nest when we came nearly opposite to her, about 150 yards off. She was a fine large Ringtail, and soared high over the hills. The eggs were all just chipped by the approaching extrusion of the young. I took one of the eggs, to see the development of the chick; it was quite naked, but the bill perfectly formed. The keeper tells me that the whole six eggs were laid twenty-seren days ago ; therefore it must take about thirty days to hatch them."

\section{Circus cinerascens . . . . . . Vol. I. Pl. XXVII.}

Astr-coloured Harrier.

Although I have called this species by the above appellation, it is far better known to British ornithologists by the trivial name of Montagu's Harrier. The wings of this bird are long and curved; and its large fan-shaped tail, crossed by numerous chestnut-coloured bars, must render it very conspicuous during fiight. Judging from the result of my own observations, I should say that this is the commonest of the Harriers, and that it is certainly the one most universally dispersed over our islands. Its breeding-places have been found mole frequently in Cornwall and other southern and western counties than elsewhere. So widely does this bird range that it is to be found in most of the countrics between Europe and China.

I hare mentioned that reptiles form no inconsiderable portion of the food of the Harriers, and in confirmation I may quote the following passage from a letter addressed to me by my friend $\mathbf{M r}$. Gatcombe, on the 3rd of May, 1872:- "A few days since, I had a fine old male Montagu's Harrier brought to me. It was killed on Dartmoor ; and from its crop and stomach I took no less than fourteen. lizards, of two kinds, all nearly perfect, and each full 6 inches long."

\section{Family STRIGID艮.}

In round numbers there are about 200 different species of $0 \mathrm{wls}$ distributed over the surface of the globe, only twelve of which were known to Linnæus, by whom they were included in one genus, Strix. The entire group are now divided into two great divisions, Nocturni and Diumi, and these again into minor subfamilies, genera, and subgenera, just as the ornithologist may please to consider them. In England there are ten species, belonging to as many genera. As might be supposed, so large a family of birds vary in size from that of a small Eagle to that of a Sparrow. So extensively are they distributed over the world, that it is almost only in the arctic and antarctic 
regions that they are not found. They are fewest in New Zealand and Polynesia, and are perhaps more abundant in Australia than elsewhere, not less than six species of true Strix inhabiting that country, besides others pertaining to different genera, all of which find a ready means of subsistence in the many small anomalous quadrupeds of that anomalous section of the earth's surface. The exeess in the numbers of the White or Barn Owls as we call our bird, doubtless keep a wholesome check upon the undue increase of the small animals alluded to. How strange (is it not?) that the neighbouring country of $\mathrm{New}$ Zealand should be destitute of small mammals and of White 0 wls! But this is not the place to enter into a disquisition on the subject; let us proceed to an enumeration of the Owls of our own country.

\section{Genus Strix.}

\section{Strix flamMes}

Vol. I. Pl. XXVIII. BARN-OWL.

A strictly nocturnal species, living principally upon mice, insects, and reptiles. Distributed over the three kingdoms and Europe generally. The slight damage attributed to this bird is far over-balanced by the good it effects in the destruction of obnoxious animals.

\section{Genus Syrniom.}

\section{Strnium aldeo}

Tawny or Brown OwL.

Distributed over England and Scotland, but extremely rare in Ireland, if, indeed, it ever occurs there. Lives on mice, rats, moles, and other small quadrupeds; the edges of pouds, too, are frequently examined for any fish that may expose themselves, which it readily seizes. The less its general character is examined the better for its reputation: for, truth to tell, it is a stealthy thief, and commits great depredation among young game, robs the keeper's pens, and does not disdain a chicken ; in fact, in prowling habits it is not surpassed by any other species. It is a bird but seldom seen either by day or night; and were it not for its merry hoot, uttered in the stillness of the evening, its presence and whereabouts would not be easily detected. It doubtless destroys rats, weasels, and young rabbits in abundance; and this is about all the good it can be said to effect. Besides our islands, the other parts of Europe are constantly frequented by this bird; but for any further particulars respecting it and its habits I must refer the reader to my account of the species accompanying the plate.

\section{Genus Buво.}

The birds of this genus are but few in number; and of these only one favours Britain with its presence; but that one is the finest of the whole. 
36. Buno maximus . Vol. I. P1. XXX.

Eaghe OWL.

This truly magnificent $O w l$, which is not surpassed in size or beauty by any member of its family, is a native of Norway, Sweden, Russia, Germany, the Italian States, Greece, and Siberia, but not India (where its place is occupied by the Bubo bengalensis), nor America (in which it is represented by the Bubo virginumus). It sometimes comes to England : and it is to be regretted that its visits are not more frequent; for so fine a bird must be an ornament to any country.

The learned are at variance as to whether this species or a little unpretending Athene was one of Minerva's favourite birds; both have always inhabited the country around $\Lambda$ thens. I must leave it to those who take an interest in classic lore to settle this point to their own satisfaction.

\section{Genus Oтus.}

The members of this section of the Owls inhabit both the Old and the New World, but are not very numerous in species. Their fiery eyes and long cat-like ears render them conspicuous objects, whether seen amidst their native woods or as mounted specimens in a museum.

\section{Otus vulgaris}

\section{LONG-EARED OWL.}

$\Lambda$ constant resident, frequently deposits its eggs in the deserted nests of Crows and other birds, and is partial to pine trees. As its brilliantly coloured eyes indicate, it often flies in the daytime. Feeds upon mice, small birds, and such other food as is commonly eaten by 0 wls.

"The Long-eared Owl," says Mr. Stevenson, " is another instance of the changes which have taken place in a few years from local causes in the habits of some of our feathered visitants. Whilst drainage and the plough are fast driving the Harriers and other fen-breeders from their accustomed haunts, the rapid increase in our fir plantations, especially near the coast, affords such inducements to this species to remain and breed with us that the autumn visitant of a few years since, only known to stay through the summer occasionally, may now be more properly termed a numerous resident, receiving additions to its numbers in autumn."

\section{Genus Brachyotus.}

Of this form but few species are known. They mostly fly near the ground, but will often mount high in the air. The action of their wings appears to be of a heavy flapping eharacter, due probably to the rounded form of those organs. 
38. BRachyotUs palustris

Vol. I. PI. XXXII.

Sitort-eared Owl.

This is both a resident and a migratory species; for, although it breeds in many parts of the British Islands, partieularly in Scotland, great numbers arrive in autumn, at the same time that the Woodcock appears ; and hence it is known in some of our counties by the name of the Woodcock-Owl. Full particulars will be found in the pages of letterpress opposite the plate.

Inhabits the moorlands and not the woods, lives upon small quadrupeds and the young of the Grouse and other birds frequenting similar districts. In Norway it feeds upon lemming; it doubtless eats lizards also; and insects probably form part of its diet. Mr. Robert Gray states that in the west of Scotland he has seen this bird "hawking for prey in dull weather at midday over turnip-fields, looking probably for field-mice, which in the autumn months become rather numerous in some places. This $0 \pi \mathrm{l}$, indeed, may be looked upon as a useful friend to the farmer in the localities it frequents."

\section{Genus Scors.}

Several members of this genus inhabit the northern portions of the Old World ; and others are found in the New. They are generally rery prettily ornamented; and their bright yellow eyes, conspicuous ear-tufts, and the harmoniously blended grey and brown moth-like markings of their plumage render them objects of especial interest.

39. Scops zorci.

Vol. I. Pl. XXXiII.

Scors Owt.

As is the case with many other species of birds, it is difficult to define what is the proper home of this beautiful little $0 \mathrm{wl}$; but we may with certainty state that it is common in France and all the southern states of Europe. Although it may occasionally breed in England (and Mr. Harting has enumerated twenty instances of its occurrence), it can only be regarded as one of our chance visitors.

Mr. Robert Gray remarks :- "It is a somewhat curious feature in the history of the Scops Eared Owl that it lires wholly upon insects. It is therefore, in temperate countries, strictly migratory in its habits; and in France, where it is not uncommon, it is said to come and go with the Swallow."

\section{Scops asio.}

Mottled Owl.

A native of North America and Canada, which it is necessary to notice because it is said to have been twice killed in this country; but, as Mr. Harting remarks, "its occurrence in England must be considered doubtful."

"This small North-American species," says Mr. Stereuson, " was 
first included amongst the accidentul visitants to this country by the late Mr. Yarrell in the third edition of his 'British Birds,' in which will be found the notice of a specimen shot in the neighbourhood of Leeds in 185', of which a figure and description were given in the 'Naturalist' for the same year (p. 169). Mr. Gurney informs me that some years back he purchased from the late Mr. Thurtell an adult specimen of this rare $0 \mathrm{wl}$, said to have been killed near Yarmouth, lout till then supposed to be only a European Scops Owl. 'This bird was unfortunately destroyed after it came into Mr. Gurney's possession."

\section{Genus Nrctea.}

Of this form the single species known is exclusively an inhabitant of the high northern regions of both the Old and the New World.

\section{Nyctea Nivea}

Vol. I. Pl. XXXIV.

\section{SNowy Owl.}

I have always regarded this bird as an accidental visitor to England, Scotland, and Ireland; but Mr. J. H. Dumn informs me that forty-five years ago it bred every year on the hills about four miles from Stromness, and Mr. Robert Gray says it may almost bo regarded as a regular spring visitant to the Hebrides. Its great size and powerful claws indicate that quadrupeds of considerable bulk are within the compass of its destructive powers; and hence the hare, the lemming, white grouse, and the ptarmigan have but little chance of escape when once enclosed within the grasp of its talons, Its proper home is the icebound regions of the north; in Lapland it follows the lemmings in their migration southwards.

"So little has been published in England," says Professor Newton, when exhibiting some rare eggs at a meeting of the Zoological Society (Dec. 10, 1861), "respecting the Snowy Owl's manuer of nidification that I hold myself excused for presenting the information I have been able to collect on the subject. . . . According to Herr Wallengren, Professor Lilljeborg, on June 3rd, 18+3, found on the Dorrefjeld a nest of this bird containing seven eggs, placed on a little shelf on the top of a bare mountain far from the forest and easy of access. Professor Nilsson mentions, on the authority of Herr A. G. Nordvi, that the Lapps in East. Finmark assert that the Snowy Owl lays from eight to ten eggs, in a little depression on the bare ground on the high mountains. These accounts were in every way corroborated by the information obtained by Mr. John Wolley during his long sojourn in Lapland. He several times met with persons who had found nests of this 0 wl, and states that he was told the old birds sometimes attack persons that approach their nests. . . They seem to breed commonly in the distriets explored by him only when the lemmings are unusually abundant. From the 16th to the 24th of May is supposed to be the time when they usually breed; and in 1860 a Lapp, who was unfortunately not one of his collectors, found a nest with six eggs, which, instead of preserving, he ate. 
"Many specimens, said to be eggs of this bird, hare lately been received by European oologists, the majority of which are from the missionaries in Labrador. One of those I now exhibit I obtained from Herr Möschler. He receired it, with sereral others, in 1860 , from the Okkak, one of the four stations maintained on the coast by the United Brethren. He has had in all more than two dozen from that quarter. The Esquimaux find and bring them to the missionaries; and the accounts they rive tally exactly with those I hare just quoted from other sources. The bird always breeds on the ground in bare places, and often lays a considerable number of eggs."

\section{Genus Sornia.}

Hitherto the birds of this form inhabiting Northern Europe and the northern parts of America have been regarded as identical, in which case the genus would consist of a single species; but, at a recent meeting of the Zoological Society, Messrs. Sharpe and Dresser havo endeavoured to show that the American bird is different from the European.

42. SuRNiA FunereA

Vol. I. Pl. XXXV.

НАшк OWц.

Six or seven instances of the occurrence of the Hawk Owl in Britain are on record.

\section{Genus Nrctale.}

The only member of this genus known to hare been found in England is the Nyctale Tengmalmi, of Northern Europe and North America.

43. Nrctale tengmalmi Vol. I. Pl. XXXVI. 'Tengmalm's OwL.

Although Mr. Harting enumerates twenty instances of the occurrence of this bird in various parts of our islands, it must still be regarded as a rare and uncertain visitor. Its range extends orer Europe and Northern Asia, as far south as Nepaul; and if, as Mr. Elliot belieres, the species known as $N$. Richardsoni be identical with it, then the morthern and arctic portions of North America must be included within the circuit of its domain.

z.

\section{Genus Athene.}

This section of the Owls comprises many species, distributed over Europe, India, and other portions of the Old World. By modern systematists these have been subdivided into no less than fifteen subgenera, the particulars of which need not be detailed here, inasmuch as we have only to deal with the single species which visits our country. 
LitTie ()WL.

A very common bird in France and other parts of Europe. In England it may have and doubtless has occurred more frequently than has been supposed; but it is a bird which cannot be easily detected, however diligently it may be searched for. Numerous instances of its occurrence are on record: and besides the nest mentioned by Hunt as having been taken at no great distance from Norwich, another is reported to have been met with in the New Forest, and the young taken and reared at Harrow.

\title{
ORDER INSESSORES.
}

\author{
Family CAPRIMULGID $\mathbb{E}$.
}

Members of this great family of nocturnal birds frequent the warmer portions of almost every part of the globe, and are nearly as raried in structure as they are numerous in species. In the New World the care-loving Steatomis and the long-tailed Hydropsales are among the most conspicuous of the forms inhabiting that section of the world, as the great Podargi and the eared Lyncomithes are of the Old. Their food mainly consists of insects and their larre, with occasionally fruits and berries.

\section{Genus Caprimulgus.}

The birds of this restricted form are confined to the Old World, over the greater portion of which they range. Two are found in Great Britain.

45. Caprimulgus europ无us . . . . . . Vol. II. Pl. I.

NightJar or Goatsucker.

The Nightjar, Goatsucker, or Churn-Owl, by which trivial names this species is known, is a true migrant, and is very generally dispersed over the British Islands from its arrical in May until its departure in September.

46. Caprimulgus ruficolits . . . . . Vol. II. Pl. II. RED-NECKED GoatsUcKeR.

An inhabitant of Spain, North Africa, and Palestine, which has once appeared in our islands. 


\section{Family CYPSELID虑.}

The Swifts have been divided into two subfamilies, Cypsetince and Choturince. They are found both in the New and the Old World. Two of the Cyspseliner occur in Britain; and one of the Chesturince having in a single instance been killed here, it becomes necessary to include it in the list of our avifauna.

Genus Crpseitus.

47. Cypselus apus

Vol. II. Pl. III. SwifT.

Arrives in May and departs southward in August or the early part of September, and is therefore a true migrant.

48. Crpselets melibi

Vol. II. PI. IV.

Arpine Swift.

A common migrant on the continent of Europe, particularly in its central and southern parts; it also inhabits Africa and India, and is an accidental visitor to Britain.

\section{Genus Cimжtura.}

The members of this genus are generally dispersed over America; nor are they absent from Asia, Africa, or Australia. They have been divided into several subgenera: that of Hirundapus has been assigned to the single species which in a solitary instance has found its way to Britain ; but I retain it under the older term by which it is more generally known.

\section{Chetura caudactia.}

\section{Spine-tailed Swift.}

The solitary example above alluded to was "shot about 9 P.x. on the 8th of July, 1846, by a farmer's son, near Colchester, in Essex; he saw it first in the evening of the 6th. He tells me it occasionally flew to a great height, was principally engaged in hawking for flies over a small wood and neighbouring trees; being only wounded, it cried very much as it fell, and, when he took it up, clung so tightly to some clover as to draw some stalks from the ground" (T. Catchpool, jun., in the 'Zoologist' for 1846, p. 1493).

If Indian, Chinese, and Australian examples are identical, as I believe they are, then the range of the present species is wide indeed; but possessing, as it does, rast wing-powers, there is no reason why it should not pass and repass from one country to another with the greatest ease. Distance being mere child's play to a bird so largely endorved with the means of flight, its accidental occurrence in England need not excite surprise. 


\section{Family HIRUNDINID A.}

The members of this great family of air-frequenting birds are almost universally dispersed, so much so at least that Swallows and Martins are known to the inhabitants of most parts of the globe, except those of New Zealand and Polynesia, where, strange to say, none are to be found.

More than a hundred species are enumerated in our lists, in which large number many variations of form exist, each characterized by some peculiarity in habits, mode of life, kind of food they eat, construction of nest, or mode of nidification. Three migratory species, each pertaining to a distinct genus, make our islands a temporary resting-place during the months of summer.

\section{Genus Hirundo.}

The species of this form, of which our common Swallow is the type, inhabit Europe, India, China, and North America. They are distinguished for the elegance of their structure and the ease and buoyancy of their evolutions.

50. Hirundo Rustica

Vol. II. Pl. V.

Comyon Swallow.

Comment upon this familiar species is quite unnecessary; we all know it arrives in spring, and, after bracketing its cup-shaped nest in our chimneys and outhouses, and rearing its progeny upon the insects it eaptures in their neighbourhood, departs again in autumn to more southern climes, earrying with it our God-speed for its welfare until it returns to receive our renewed greeting.

\section{Genus Cheumon.}

Other species besides the clothed-tarsed one frequenting our island are known; thes are mostly from India, China, and Japan.

\section{Chelidon urbica}

Vol. II. Pl. VI. Hodse-M $\Lambda$ RTin.

This pretty fairy-like bird arrives about the middle of April, constructs a semiglobular nest of mud under the eaves of our dwellings, and, after rearing its progeny, departs again in the autumn to the warmer country of Africa-where the sun still vivifies an abundance of insect life, and thus furnishes a plentiful supply of food to these insectivorous birds.

\section{Genus Cotrue.}

A very distinct little group are the Sand-Martins, whose habits are peculiar and very different from those of the Swallow or the House-Martin. They inhabit the Old and the New Worlds. 
52. Cotyle riparia

Sind-Martin.

Arrives early in spring, assembles in flocks, breeds in colonies, makes a slight nest in a hole in a sandbank, and, after rearing its young, departs south on the first chilly days of August or September.

53. Cotyle riparia . . . . . . Vol. II. Pl. Vili.

SAND-MARTIN (young)

as seen, on the bank of the Thames, in the month of August, prior to departure south.

54. Progne purpurea.

Genus Progne.

\section{Purple Martin.}

A strictly American form, of which four or five examples are said to have been killed in our islands-one near Dublin, one in Yorkshire, and two at Kingsbury in Middlesex.

55.

$$
\text { Genus — ? }
$$

\section{White-bellied Swallow.}

Another American form, for which a generic title has not yet been proposed. It is said that a specimen has been killed near Derby; ride Wolley, in the 'Zoologist' for 1853, p. 3806, and Newton in 'Proceedings of the Zoological Society' for 1860, p. 131.

\section{Family MEROPID瓜.}

The members of this family are among the most ornamental of the Insessorial birds, and are as elegant in form as they are beautiful in colour. Europe, Asia, Africa, and Australia are the countries in which one or other of the not very numerous species are found. As the thinness of their plumage and the slightness of their form would indicate, they appear to be sensitice to cold; and most of them are resident in the tropical or warmer portions of the countries mentioned, though one species, the Merops apiaster, is very common in Spain. Insects of the various orders constitute their chief food. The species hare been dirided into sereral genera.

\section{Genus Merops.}

The species inhabiting Europe is the type of this form.

56. Merops apiaster Vol. II. Pl. IX. BEE-EATER.

Although there are many instances of the occurrence of this bird in Britain, it can only be regarded as an accidental visitor; and 
so uncertain are its visits, that years may elapse without an example being seen. It is common, and breeds, in Spain, where it deposits its eggs in holes of sandbanks.

\section{Family ALCEDINID E.}

The distribution of the Kingfishers may be said to be almost universal; but of the 125 species described, few are to be found in the New World, the family being very feebly represented in America. The various species have been much subdivided and received many generic appellations, their structure being as diverse as their modes of life and the kinds of food upon which they subsist. Water is by no means essential to the existence of many of them, especially those which dwell amidst the scorix of volcanoes and on hot and parched plains,-lizards and insects being the food of those affecting the former situations, while the huge Dacelos (frequenting the latter) eat snakes, small quadrupeds, and insects. Fish appears to be the chief food of the members of the restricted genus Alcedo, of which our well-known Kingfisher is the type.

Genus Alcedo.

57. Alcedo ispida . . . . . . . . . Vol. II. PI. X.

KTNGFISHER.

A resident species; common in all the central portion of England, more scarce in Scotland, and not a common bird in Ireland. Feeds on fish, crustaceans, and insects. It is the only species which habitually lives in Britain and on the continent of Europe, beyond which its range is not very far extended. Other species of this form inhabit India, some of its islands, and Africa.

\section{Genus Cerryle.}

A group of Kingfishers, of about a dozen or fifteen species.

\section{Certule ajcyon.}

This American bird has been twice killed in Ireland-once in the county of Meath in October 1845, and again in the county of Wicklow in November of the same year (Thompson, 'Natural History of Ireland, Birds,' vol. i. p. 373). 'These 'Transatlantic birds must be regarded as interlopers, since they have no just claims to a place in our fauna.

\section{Family CORACIIDAE.}

No member of this family has yet been seen in the New World; and the old may claim the form as one of its finest ornithological 
productions. There are ereu fewer species of this family than of the Meropides; and those few are all warm-country birds. They are abundant in Africa; one or two species frequent India; others the islands of the Eastern archipelago. Up to this time no true Roller has been found in Australia, where it is represented by the members of the genus Eurystomus.

\section{Genus Coracias.}

59. Coractas garrula . . . . . . . Vol. II. Pl. XI. ROLLER.

Although the Roller is a regular summer visitant to the centre of Germany and other parts of the Continent, its occurrences in England have been few and far between; here, therefore, it can only be regarded as an accidental risitor. It has nevertheless been occasionally killed in the three kingdoms.

\section{Family UPUPID在.}

Varied indeed are the opinions entertained by ornithologists respecting the situation this fimily of birds should oceupy in our systems. For my own part, I have always considered its proper place to be near to, if not associated with, the Hormbills (Bucerotide); hence this is perhaps not the situation in which it would appear in an arrangement of the birds of the world; but it is the best I can assign to it in a limited fauna like that of the British Islands.

\section{Genus Uptpa.}

About five species of this very singular form are known; they inhabit Europe, Asia, Africa, and Madagascar.

\section{UPUPA EPOPS}

\section{HoоpoE.}

An accidental visitor to England, where it generally arrives in May; and its doom is sealed as soon as it makes its appearance: so attractive a creature immediately arresting attention, it soon falls a victim to the gunner; and its mounted skin is found in the houses of the men of Kent and other southern counties.

\section{Family LANIID A.}

The Shrikes, comprising many species, are very generally distributed over the surface of the globe, particularly in the Old World. Some of the typieal members inhabit Britain and North Ameriea, and are also found in Asia and Africa, but not in the islands of the Eastern archipelago, nor in Australia. They are all, to a certain 
extent, destroyers of other birds; but their chief food consists of insects, their larvæ, and mollusks. In disposition they are cruel, spitting their victims on thorns or between the interstices of the branches of trees; for what precise purpose is not well understood.

\section{Genus Lanios.}

61. Lanius excubitor . . . . . . . Vol. II. Pl. XIII.

\section{Great Grex Shrike.}

An accidental visitor, which may occasionally, but does not usually breed in this country. Its proper home is the continent of Europe, beyond the boundary of which it becomes more and more scarce.

62. Thaniug minor . . . . . . . . . Vol. II. PI. XIV.

Rose-breasted Shrike.

A native of Spain, Turkey, and Greece, which has been killed two or three times in England.

\section{Genus Enseoctonos.}

The members of this genus differ considerably from the preceding, inasmuch as, instead of the sexes being alike, they vary in colour and markings. Species of this form are found in Europe, Asia, and Africa.

63. Enneoctonus collurio . . . . . . Vol. II. Pl. XV.

BUTCHERBIRD.

A migrant from the south in May, and returning thither early in autumn.

64. Enneoctonus rufus . . . . . . Vol. II. Pl. XVI.

Wood-Chat.

Although this bird has been killed in England sereral times, it can only be regarded as an accidental visitor. It is said to have bred in this country; but, for myself, I have never seen an authenticated egg which had been taken herein.

\section{Family MUSCICAPID E.}

The various members of this family are very generally dispersed over the countries of the Old World.

When I published my Plates of the two following species, the late Mr. George R. Gray had recently indicated, in his 'Catalogue of British Birds,' that the old Muscicapa atricapilla pertained to the genus Muscicapa, and the M. grisola to the genus Butalis; but in 
his more recent ' Hand-list' he makes the latter the type of MLuscicapa, and places the former under Sunderall's subgenus Hedymela.

\section{Genus Muscicapa.}

65. Muscicapa atricapilla. . . . . . Vol. II. Pl. XVII. Pied Flycatcher.

A well-known migrant to Britain, chiefly frequenting the northern portion of England, where it breeds. It is rarely met with in Scotland, and never in Ireland. For an interesting note by $\mathrm{Mr}$. Stevenson on a singular imnigration of this speeies on the Suffolk coast in September 1869, see the 'Zoologist' for that year, p. 1492.

66. Muscicapa collatis . . . . . Vol. II. Pl. XVIII.

White-collared Flycatcher.

This species, which has once been killed in England, is a native of Eastern Europe.

Genus Butalis.

67. Butalis grisola . . . . . . . Vol. II. Pl. Xix.

Spotted Flycatcher.

Arrives late in the spring, spreads over the British Islands, and after breeding returns to whence it came, the northern part of Africa.

\section{Genus Ertihrosterna.}

The members of this genus, which are but few in number, frequent Eastern Europe, India, and China. They are extremely delicate in structure; and it is marvellous how so frail a bird as the $E$. parve could have crossed the Channel, and thus laid claim to a place in the avifauna of Great Britain.

68. Erythrosterna parta . . . . . Vol. II. Pl. XX.

\section{Red-breasted Flycatcher.}

For the particulars respecting the capture of three examples of this bird, I refer my readers to my account of the species opposite the Plate; but I may here mention that all were taken in Cornwall, and that they can only be regarded as accidental visitors.

69. Vireosyluia oltvacea.

Red-eyed Flycatcher.

In Mr. Harting's 'Handbook of British Birds' it is stated that two examples of this purely American species were taken by a birdcatcher at Chellaston, near Derby, in Nay 1859, the particulars of which will be found in Sir Oswald Mosley's 'Natural History of Tutbury,' page 385. 


\section{Family AMPELIDE.}

Three or four species of this rery singular and beautiful family are all that are known. They chiefly inhabit the temperate and northern regions of both the Old and New Worlds, their summer residences often bordering the arctic circle, whence some of them migrate south at the cold season, but only for a short period.

\section{Genus Ampetrs.}

\section{Ampelis garrulus . . . . . . Vol. II. P1. XXI \\ WaXen ChatTerer.}

A native of Norway, Finland, and Russia. Is only an accidental visitor to England; and when it does favour us with its presence, it is mostly in the winter, especially if that season happens to be severe. A distinct species is found in Japan; and the A. cerlromm, as we all know, frequents America.

\section{Family SITTID压。}

Taking our Common Nuthatch as a typical example, and omitting the members of the allied subgenera Callisitta, Dendrophila, and Hypherpes, there exist about a dozen species of this family, some, if not all, possessing the peculiarity of being able to run up and run down the boles of trees with equal facility. They frequent the temperate portions of Europe, Asia, and America.

71.

Vol. II. Pì. XXII.

\section{Nuthatch.}

This species is not, as has been supposed, entirely confined to Britain ; for it is also found in some of the Danish islands and elsewhere. With us it is stationary and common all over England, but is somewhat rare in Cornwall, very scarce in Scotland, and never found in Ireland.

\section{Family PARIDA.}

More than a hundred species of Tits have been already named; and there are doubtless many more yet to be described. The countries frequented by these tree-loving birds are Europe, Asia, Japan, the Philippines, Java, and Sumatra. Africa, also, from north to south, contains its fair quota; nor are they absent from America, in which country they are principally found in its northern regions. Structurally they present much variety; and in consequence the entire group has been divided into many genera. In the British 
Islands, exclusice of the so-called Bearded Tit, which belongs to an entirely different family, we have six species, which constitute the typical examples of almost as many genera. I have, howerer, only adopted a portion of them, keeping four in the genus Parus, one in Pocile, and one in Mecistura. The chief food of the Tits consists of insects and their larræ, with occasionally the addition of fruit. They are mostly pert and lively birds, assuming many varied positions while searching for food among the leafy branches of trees and shrubs.

\section{Genus Parus.}

72. Parus major

Great T'tr.

Resident and common orer the three kingdoms. Breeds in April and May. Youthful birds have their cheeks stained with yellow, while in the adult the sides of the face are white.

Generally distributed over Central Europe.

\section{Parus centuleus}

Vol. TI. PI. XXIV.

Brue Tit.

A beautiful saucy little bird, which, being found here at all times, is a resident species. The cheeks, which are white in the adult, are tinged with yellow in the young. As common in the central portion of Europe as with us.

74. Parus ater

Tol. II. Pl. XXY.

CoAs 'Tit.

A common resident in every county ; gires preference to forests of beech and oak. A cheerful, merry little bird, of which the young are more beautifully coloured than the adult, the sides of the face and a portion of the breast being washed with yellow during the first six weeks of their existence. The contimental birds, particularly those found in Belgium, are considered distinct by Messrs. Sharpe and Dresser.

75. Parus cristatus

\section{Crested T'tr.}

A resident species in Scotland; breeds in the woods near Elgin. Is said to have been killed in England, and, on the authority of Mr. Blake-Knox, twice in Ireland.

\section{Genus Poectle.}

76. Pechle palustris . . . . . . Vol. II. Pl. XXVII. Marsh-Tre.

A resident species; scarce in Scotland, except in the Lothians, and still more so in Irelaud. Cheek-mark of the young uniform with 
the other parts of the body, except the sides of the neck-which are white, and not yellow. Frequents, but not exclusively, plantations, copses, and low humid situations.

\section{Genus Mecistura.}

77. Mecistura caudata . . . . . Vol. II. Pl. XXVIII. Long-TaIled Tít.

This wandering and interesting bird is a true British resident. It has been separated by Mr. Blyth from the White-headed species of Scandinavia, under the specific appellation of rosea ; it must, however, be remarked that some of our examples have white heads; and therefore I do not aver that they are, or are not, distinct. Other species of this form are found on the Bosphorus, on the Himalayas, and in China.

Mr. J.H. Gurney, jun., has communicated to me the following interesting fact in connexion with this bird:- " A Mr. Noble once noticed at Blackwall, near Darlington, an object on a fir tree which he took for a Pheasant; but on firing at it he found that, instead of a Pheasant, it was a great ball of Long-tailed Tits. He told me that he did not kill less than a dozen. My father informs me that the South-African Colies roost congregated in bunches;" and I have witnessed precisely the same in the Artamus sordidus in Tasmania.

78. Mecistura caudata . . . . . Vol. II. Pl. XXIX. LoNG-TAILAD Tit (joung).

Family ?

Genus Calanophirus.

79. Calamophilus brarmitud . . . . Vol. II. Pl. XXX. Bearded Tit.

A resident species in the marshes and along the sides of the rivers of our eastern counties; but the drainage of the former and the clearance of the sedges of the latter have greatly diminished the numbers of this lovely little bird. Still it is common with us, and even more so in Holland and other fluriatile districts of Central Europe.

This bird is by no means a genuine Tit, although it is commonly so called, and is placed here for the want of a more natural situation.

Family ORIOLID E.

A group of Old-World birds, the members of which are beautifully coloured, yellow and black being the prevailing tints, particularly 
of that seetion of them typified by the Oriolus galbula. The countries they frequent are either hot or temperate, Africa, India, China, the Philippines, Java, Sumatra, and some of the islands of the Eastern Archipelago being tenanted by one or other of the species.

\section{Genus Ohiolus.}

\section{Oriolus galbula . . . . . . Vol. II. Pl. XXXi.} Golden Oriole.

Although common in many parts of Europe during the breedingseason, with us it is a rare bird, and must be included among our accidental spring visitants. In the Scilly Islands five or six are often seen together; but after remaining there quite unmolested for two or three weeks, they invariably betake themselves to the mainland, where persecution and death await them. The following note from my friend Mr. Rodd, respecting an unusual irruption of this species, will be read with interest; it was received on the 24 th of April, 1870. "I am sure you will be interested in hearing that a large immigration of Golden Orioles has taken place in the immediate neighbourhood of Penzance and at the Scilly Isles. They are mostly in superb adult plumage. Five were killed out of eight, and a fine male and a female besides, at Trevethoe, near Hayle. A flock of forty or fifty was risen in a thick plantation on the grounds afterwards." Surely such beautiful birds, when they do arrive in this country, should receive protection instead of the destruction which now invariably awaits them.

\section{Family TURDID $A$.}

A large number of medium-sized insessorial birds are included in this family - Thrushes, Blackbirds, Fieldfares, Redwings, \&c. Their omnivorous appetite leads them to eat insects and their larva, snails, worms, fruits, and berries. Some are constantly resident, others are migratory; some spend the summer, others the winter with us,

\section{Genus Turdus.}

The Thrushes and the Blackbirds are seemingly very different; and were it not for numerous intervening forms, the generic characters of Turdus and Merula would be more easily defined. The greater part inhabit the temperate portion of the earth, but are not found in Australia or New Zealand.

\section{Turdus yusicus . . . . . . . Vol. II. PI. XXXII.}

\section{Throsh.}

Very generally distributed, and constantly residing and breeding here, as it does also in most parts of the European continent. 


\section{Turdus VIscIVorUs . . . . . . Vol. II. Pl. XXXIII.}

\section{Missel-Thrusir.}

Strictly stationary. Common in Europe ; generally breeds in all the middle counties of England. It also inhabits Scotland, where it is anuually becoming more and more numerous. Sings early and breeds in May. The following note from Professor Owen, dated Sheen Lodge, Richmond Park, 28th April, 1872, respecting the pugnacious propensities of this species, cannot fail to be of interest:- "You know that the Missel-Thrush boldly attacks Magpies and other birds larger than itself; but you may not be aware that it bullies man himself. I was transplanting, about sunrise this morning, and was startled by a loud menacing noise above me, and on rising and looking up saw a Missel-Thrush darting from branch to branch, chattering loudest as it passed over and near to my head; and then it made a dash at me, sweeping close past my face with a chattering scream, and, alighting on a branch about six yards off, turned ronnd and dashed back again, so that I 'ducked' to save my eyes; and these sweeping attacks were repeated four or fire times before (out of a desire not to disturb a bird whose wild winter-notes I like) I moved off. I went a roundabout way to a garden-seat about twenty yards from the scene of the first disturbance, and shortly after heard the same chattering, clattering, bullying note, and, haring my binocular, made out my friend (or enemy) darting about the boughs of au old acacia orerhead, and continuing his remonstrances against my vicinity, to which I again yielded."

\section{Turdes iliacus}

Vol. II. Pl. XXXIV.

REDWTING.

A winter visitant, arriving with the Fieldfare in autumn, and departing northward in the spring. Summers in Iceland, Norway, Sweden, and other portions of the old continent bordering the arctic circle.

\section{TURDUS PILARIS}

Vol. II. P1. XXXV.

\section{Fielifare.}

A winter risitant only. Breeds in Norway and many other parts of the Old World. Comes to us about the same time as the Woodcock-that is, in October, the period when the Ring-Ouzel departs.

85. TURdus atroguläis

Vol. II. PI. XXXVI.

\section{Black-throated Thrusi.}

A native of Eastern Europe and Northern Asia. Has been once killed in England, as will be seen on reference to the Turdine section of the work, where the circumstance of its capture near Brighton is fully detailed. 
Genus Merula.

86. Merula velgaris Vol. II. Pl. XXXVII. BLACKBIRD.

A resident and very generally distributed species, both in our islands and on the European continent.

87. Merula torquata. . . . . Vol. II. Pl. XxxVIII. RiNG-OdzeL.

A summer visitant, which frequents rocky situations in Wales, the northern parts of England, Scotland, \&e. Winters in Africa.

\section{Genus Oreocincla.}

$\Lambda$ form very distinct both from Merula and Turdus, of which five, six, or seveu species, all inhabitants of the Old World, are known to exist. They have a very wide range, some being found in Asia and its islands, and others in Australia. They are shy and solitary in their habits, often frequenting rocky and scrubby situations in the midst of forests.

88. Oreocincla atred . . . . Vol. II. Pl. XXXIX. White's Thrush.

A native of the Altai, the Himalayas, and China. Single individuals occasionally migrate westward to the coutinent of Europe and to England, wherein about ten or twelve examples have been killed, the particulars respecting several of which will be found in the letterpress opposite the Plate of the species.

\section{Genus Cichloseris.}

An eastern form, the type of which is the well-known Siberian Thrush.

89. Cichloserys sibiricus . . . . . . . Vol. II. Pl. XL.

Siberran Throsir.

Quite an accidental visitor, only a single in stance of its being killed here being on record.

\section{Family PYCNONOTIDE.}

The members of this family are nearly allied to the great group of Honey-eaters (Meliphagidce) of Australia. Nany species inhabit Africa and India.

Genus Prononotus.

90. Prenonotus capensis.

Gold-vented Thrush.

A native of Spain and part of Africa; once killed in Ireland-for 
the particular's of which see Thompson's 'Birds' of that country, and Yarrell's ' History of British Birds,'vol. i. p. 224: "erroneously' identified by those authors," says Mr. Harting, "with $P$. aurigaster of Vieillot."

\section{Family CINCLIDAE.}

Many opinions are extant among ornithologists respecting the natural position of this very singular group of birds : one places them near Enicurus, Grallina, de.; another fancies they are allied to Troglodytes; and a third, to the Thrushes. Of the eleven or twelve known species, seven or eight inhabit the northern regions of the Old World; a single, or at the utmost two, frequent the same regions of the New; and two are found among the cataracts and rocky streams of the Andean ranges. But it is in Europe and Asia that Water-Ouzels most abound, the watercourses of the great Himalaya Mountains and their continuations being especially frequented by them. Europe is tenanted by three, one of which inhabits the British Islands, and a second comes to them occasionally from Norway.

91. Cinclus aquaticus. . . . . . . Vol. II. Pl. Xli Water-Ouzel or Dipper.

A resident in Britain, frequenting the turbulent waters and millstreams of its hilly districts.

92. Cinclus melanogaster . . . . . . Vol. II. Pl. XliI. BLACK-BELLIEd WATER-OUZEL.

A native of Norway, Sweden, and probably other parts of Northern Europe. In Eugland it has been several times killed in Norfolk, Suffolk, and Lincolnshire; but these must be regarded as accidental occurrences.

\section{Family SAXICOLIN 2 .}

A family of insectivorous birds, comprising many Old World forms inhabiting Europe, Asia, and Africa. They vary in size from a 'I'hrush to a Wheatear or a Stone-Chat.

\section{Genus Petrocossyphus.}

A genus of rock-loving birds common to the continent of Europe, North Africa, India, China, and the Philippine Islands.

93. Petrocossyphus cyands . . . . . Vol. II. Pl. XLTII.

Blue Rock-Thrush.

Has been once killed in Ireland, the particulars respecting which 
and the countries the bird inhabits will be gained by reference to the letterpress opposite the Plate whereon the species is figured.

\section{Genus Petrocincla.}

This form is scarcely separable from Petrocossyphus; the members of both are distributed over nearly the same parts of the world.

\section{Petrocincla saxatilis . . . . . Vol. II. Pl. Xlit. Rock-THRUSH.}

A purely accidental visitor to Britain, only one, or at the utmost two, examples having been seen therein. The true home of the species is Southern and Eastern Europe, Palestine, and North Africa.

\section{Genus Saxicota.}

The Wheatears, as the members of this genus are frequently called, are Old-World birds, inhabiting Europe, Africa, India, and China. They are alert in their actions, and dwell almost exclusively in rocky and sterile places where little water occurs, that element not apparently being necessary to their existence.

95. Saxicola cenanthe

Vol. II. P1. XLV.

\section{WhFATEAR.}

An early spring visitant from Africa. Breeds in various parts of the three kingdoms, after which both old and young retire to winter in warmer climates; some individuals proceed to high northern latitudes-Greenland, and Arctic America.

\section{Genus Pratincola.}

An Old-World form, the members of which are more arboreal than the Wheatears, frequently perching on shrubs, bushes, and grasses. They are distributed over Europe, Africa, India, and China.

96. Pratincola rubetra - . . . . . Vol. II. Pl. XlVI. Whin-Снат.

Strictly a migrant from the south, arriving at the end of April, and, after breeding, departing again to whence it came: while here, it is very generally distributed.

97. Pratincola rdbicola . . . . . Vol. II. Pl. XLVII. Stone-Chat or Furze-Chat.

A resident bird, inhabiting commons and heath-covered districts: breeds and remains in its chosen situation from year's end to year's 
end. It is also found on the continent of Europe, and probably in some parts of Asia.

\section{Genus Erythacus.}

Of this genus there are three species, the well-known Robin ( $E$. rebecul(e) of Europe, and the $E$. akatige and $E$. komadori of Japan.

\section{Erythacus rubecula * . . . . Vol. II. Pl. XlVIII.} RoBIN.

This familiar denizen of our gardens, shrubberies, and woodlands is a constant resident with us, is dispersed over the three kingdoms, and is a general favourite. It is also found on the continent of Europe, in North Africa, and the Islands of Madeira and Teneriffe, in which latter island I have myself shot examples.

\section{Genus Cranecula.}

Two or three very differently marked birds of this form exist in Europe, Africa, India, and China. By some writers they are considered to be one and the same species; by others each has been regarded as distinct. In habits and disposition the Bluethroats are peculiar, they exhibit none of the bold daring of the Wheatear and the Robin; neither do they sit on a twig and show their breasts like the Whin- and Stone-Chats; on the contrary they skulk among bushes and dense herbage of hill-sides, or among the grasses in a meadow, concealing rather than showing their beantiful colouring, as if conscious that its exposure would be adverse to their well-being.

99. Cranecula suecica . . . . . . Tol. II. Pl. XliX. Red-throated Bluebreast.

A lovely little bird, which lives in eastern Europe and probably in Africa. In the summer it is to be seen on the Dorrefjeld, in the winter in the sunny south. It sometimes pays England a visit, and hence is included in our avifauna, but its occurrence must be regarded as purely accidental.

100. Cranecula ledcocyana . . . . . . Vol. II. Pl. I.

IIITE-THROATED BLUEBREAST.

I native of France and Southern Europe, aceidental in England.

Genus Ruticilla.

Redstarts, as the members of this genus are trivially called, not only inhabit Europe, but are abundant in India and China. 
Redstart.

Arrives from the south in April, frequents our gardens, breeds in our apple-trees, and renders its visits agreeable by its pleasing song, the sprightliness of its actions, and the beauty of its plumage. It also visits the southern and central parts of Europe generally.

102. Rutichlla tithys . . . . . . . . Vol. II. Pl. LII.

\section{Black Redstart.}

A native of Central Europe and the countries to the southward and eastward thereof, pays England almost anuually a visit during the months of autumn, when other migrants have gone south to winter in $\Delta$ frica; still it must be regarded as an accidental visitor only. With us it frequents rocky situations; but on the Continent it takes up its abode in gardens, just as the Redstart does here.

\section{Genus Aedon, Boie.}

The members of this genus are inhabitants of the Old World, where their head quarters appear to be Eastern Europe and Northern Africa.

103. Aedon galactodes - . . . . . Vol. II. Pl. LIII.

Rufous Sedge Warbler.

Spain, Greece, Asia Ninor, and North Africa are amoug the countries frequented by this species, which, having been only twice killed in England, must be enumerated among its rarest visitants.

"The Rufous Sedge Warbler is evidently only a summer migrant in the north of Algeria. On my return from the Mzab country in May, I saw scores where there had not previously been one, and generally away from water. It has a curious habit of raising its tail; it is hardly ever seen in any other position. Our common British Nightingale has the same habit in a less degree; but with the Rufous Sedge Warbler it appears to be natural to keep it raised: whether the bird is in motion or at rest, the tail is only depressed at intervals."-J. H. GunNer, jun.

\section{Family ACCENTORIN A.}

A group of Old-World birds, some species of which inhabit Europe and Asia, from the British Islands to Kamtschatka and Japan. They have been subdivided into three genera, Accentor, spermolegus, and Tharrhaleus, the types of the first and third of which are natives of Britain, namely, A. alpinus and $T$. modularis. I have, however, kept them both in the genus Accentor.

\section{Genus Accentor:}

104. Accentor alpinus - . . . . . Vol. II. Pl. LIV. Alpine Accentor.

Common in Switzerland and other rocky countries of Southern and 
Eastern Europe. An accidental visitant to England, where it has been killed or seen about a dozen times.

105. Accentor modularis . . . . . . Vol. II. Pl. LV. Hede-Accentor or Hedge-Sparrow.

Resident in the three kingdoms; common in gardens. A tame, pleasing, and harmless little bird. Lives on insects. Inhabits most parts of Europe and Malta, where I have shot examples.

\section{Family SYLVIIDÆ.}

Comprises a very large number of species, which are inhabitants of the older known portion of the globe. About fifteen are enumerated in the British avifauna, as belonging to the genera Sylvia, Curmeca, Luscinia, Melizopthilus, Phyllopneuste, Ficedula, Regulus, Reguloides, \&e.

\section{Genus Luscinia.}

A very well-defined genus, comprising two species, both of which are summer birds in Central Europe. One of them, our well-known Nightingale, comes to us in spring, and retires again in autumn. It has been ascertained that both species winter in more southern climes; but we really know little respecting the extent of their range in that direction.

106. Luscinta philomela. . . . . . . Vol. II. Pl. LVI. Nightingale.

A summer migrant to the southern and central parts of England, but not to Scotland or Ireland. A full account of this charming bird will be found opposite the Plate on which it is represented.

\section{Genus Srlvia.}

In the present work both the Whitethroats have been regarded as typical examples of the genus Sylvia. These and some other species abound in Europe during the months of summer; others, again, are spread over Northern Africa, India, and China. Their food consists of insects and berries.

107. Syltia cinerea . . . . . . . Vol. II. Pl. LVII.

WHitemRoAt.

When spring assumes her most cheery aspect, our hedges put forth their leafy verdure, and the goose-grass ramifies among the herbage of the ditches, the saucy Whitethroat makes its appearance, and, after spending the summer and rearing its brood, departs again in autumn to winter in warmer climes. It is, therefore, a true sum- 
mer migrant, which risits all the three kingloms, but is rather searce in some parts of Scotland.

10S. Srlvil currucl . . . . . . Tol. II. Pl. LVIII. Lesser Whitethlo.tT.

A summer migrant from the sonth, which arrives rather later than the preceding species, betakes itself to gardens and woodlands, sings its garrulous peculiar song while searehing for aphides and other insects among the leares of the eherry-and other trees of the garden or forest, is spread orer the central portion of England, is rare in Corntrall and S'cotland, and has not been seen in Ireland.

\section{Gionus Metizophiles.}

Mr. G. R. Gray enumerates, in his recently published ' Thand-list of Birds,' three species of this genus; but I feel assured that our well-known Dartford Warblor must stand as its sole representative.

\section{J[eltzophildes provinctilis . . . . Vol. II. Pl. LIX.}

\section{DartFord Wartietr.}

A stationary but very loeal species in the sonth of England, rare in the midland and northern counties, mknown in seotland and Ireland. Evinces a preference for heathy lands, particularly those clothing the greensand; hence it is abundant in some parts of Surrey, Sussex, and Hampshire; while on the Continent, where this kind of formation does not exist, it is either scaree or cntirely absent. Is extremely shy and recluse in its habits. Breeds in May.

"Are you aware," says Mr. Gatcombe, in a letter dated Dec. 20, 1865, "that the Dartford Warbler is tolerably common in the furzebrakes near Lyme Regis? A fow days since I had a very nice specimen sent me in the flesh from that place; and the sender informed me that he had lately killed fire, but the one forwarded was the only one he could find among the long gorse. What a great pity that four of these interesting birds have been killed and lost!"

\section{Gemus Curreca.}

The members of this genus possess considerable rocal powers, are more shy or distrustful in their habits than the Whitethroats, and are less sprightly in their manners. Europe, North Afriea, Asia Minor, Western India, and China are frequented by the members of this genus, two of which visit lingland during the wonths of summer.

\section{Curruci atricapiel.}

Vol. II. Pl. LX.

\section{BLLCKCAP.}

Winters in North $\Lambda$ frica, and migrates to us in April in considerable numbers, which, after sponding the summer and breeding here, wing their wily to whence they came. Common all orer Engtanel, 
rare in Seotland and in Treland. As a songster it almost rivals the Nightingale.

\section{Curruca orphlid . . . . . . Vol. II. Pl. LXI. Orpitin Warbler.}

One specimen at least has becn killcd in lritain, for the particulars of which vide the letterpress opposite the plate on which it is figured.

\section{Currech hortensis . . . . . Vol. II. Pl, LXII. Garden-Wariler.}

An unobtrusive and plainly coloured bird; has a loud garrulous song; arrives in $\Lambda$ pril, when the nettles and other herbage are suffiriently dense and the leaves of the trees sufficiently forward to sereen it from sight. Common in England and the south of Scotland, but seems to be more rare in the north of that country ; and in Ircland, according to Thompson, it is extremely so.

\section{Genus Troglodites.}

In the old World the northern regions are those that are principally inhabited by the members of this genus; in the New they range from the northern to nearly the southern extremity of the great continent of America. They are pert, lively little birds, which differ from the true Sylvice in many particulars, rendering it very difficult to assign them a place affinitively in any of the proposed systems.

113. Troglodytes edropeds . . . . . Vol. II. Pl. LXIII. Common Wren.

As implied in its specific appellation, this bird is a native of Europe, over which it is very generally dispersed and strictly stationary, inasmuch as it keeps in the ricinity of its breeding-place from year's end to year's end.

\section{Family CERTHIID $\mathrm{E}$.}

The members of this singular bark-loring fimily, which are but few in number, frequent the temperate regions of both the Old and the New World. Four species inhabit the great Himalaya mountains; and of these some visit the plains of India, and extend their range eastward to Japan. In America there are two, which are found in all parts of that country from the Lnited States to Mexico.

Genus Certinta.

\section{Certita famiturts . . . . . Vol. IT. Pl. LXTt. Tree-Creeper.}

A resident species, generally distributed over the three kingdoms, and braving with apparent impunity the coldest of our winters. 


\section{Genus Phyllopyedsta.}

The trivial name of Leaf-W arblers has of late years been applied to the members of this gemus, a term which I regret not having cmployed in the body of the work. These delicate birds axe so generally dispersed over the northern and temperate comtries of the Old World that they may be regarded as unirersally diffused. They are all more or less migratory, moving backward and forward in accordance with the course of the sun. Three species arrive in Britain early in the spring.

\section{Phyllopnedsta trochilus . . . . Vol. IT. Pl. IXV. \\ WILLOW-WREN.}

Arrives from the south about the middle of $A$ pril, and diligently commences to search for inseets among the newly expanded leares of the willow and other trees, and, after making its dome-shaped, grassy, feather-lined nest on the ground and rearing its young, retires to whence it came upon the earliest access of cold weather. When here it is generally dispersed over the three lingdoms.

116. Pithlopnedste rufa . . . . . . Fol. II. Pl. LXVI.

\section{Cimfforiaf.}

One of the earliest spring migrants from the sumny south, many individuals frequently appearing in $1 /$ areh. Solitary instances are on record of its having been seen here during the winter months ; and as $I$ found it at the same season at Malta, it is evidently a more hardy bird than the Willow-Wren, from which it differs in the character of its song and in the places selected for the site of its dome-shaped nest, which is frequently built in a bush. It is rery generally dispersed, but somewhat less numerous in feotland than in England.

117. Phymlonvedste similitatx . . . Tol. II. Pl. Lx TII. WoOn-W Rex.

Altheugh I have liept this bird in the present genus, it has just: claims to generic distinction, its much longer wings, peculiar song, and brighter colouring not being quite accosdant with either the Willow-Wren or the Chiftchafl-and, inclecd, has had that of sitiTatrix assigned to it by Professor Kaup. With us it is a true summer visitant, arriving later than the two birds above mentioned, its tremulous sibilant note not being usually heard until Mray. Although commonly dispersed over England and ficotland, it is rare in Ireland. Breeds on the ground, generally making a nest of grasses only. Departs in autumn, and winters in Africa.

\section{Gents ReGULordes.}

Comprises a series of smatl eastern birts allied to P7yllopmouste and Rryulus. The speries which has paid England owasional visits 
is an inhabitunt of Europe and Torthern India, where others of the form are also found.

\section{Regulotdes superctitosus . . . Vol. II. Pl. LXVIIT.}

YELLOW-BROWED WARTLER.

The particulars of the eapture of this species in England, as recorded by Mr. Harting, are :-

"One, Hartley Point, Northumberland: Ilancock, Amm. and Mag. Nat. Hist. vol. ii. 1. 310; Blyth, Zoologist, 1863, p.8329; Tarrell, Hist. of Brit. Birds, vol. i. p. 380.

"One, Charlton Kings, near Cheltenham, 11th Oct. 1867: Gould, Ibis, 1869, p. 128."

Hab. Northern Asia, India, Nepaul, China, Japan, and Formosa. Has oceurred accidentally in Sweden, in Heligoland, and Berlin, and near Leyden.

\section{RegtrotDis CAIENDULL.}

Ruby-crowned Wren.

All that is known respecting the oecurrence of this species in our islands is comprised in the following' note from Mrr. R. Ciray's 'Birds of Western Scotland :-

"In the summer of 18.52, Dr. Dewrir, of Glasgow, shot a specimen of this North-American species in Kenmore Wood, on the bauks of Loch Lomoud. The bird was exhibited at a Meeting of the NaturalHistory Socicty of Glasgow on the 27 th of April, 1858 , and identified by me. Dr. Dewar stated that he had found it in company with a large flock of Golderests, and that he had shot a dozen birds altogether before he recognized the differences which this one presented. Dr. Bree, in his work on the birds of Europe, states that the Rer. II. B. Tristram has a Ruby-crowned Tinglet in his possession, which was given him in the flesh, and which was killed by a Durham pitman, in 15.5, in lirancepeth woods; from this it would seem that a second example has occurred in this country.

\section{Gentis limeulus.}

'The Ciolden-crested Wrens or Finglets are a charming group of small birds inhabiting the northern regions of the Old and New Worlds. In their actions and in their mode of nidifieation they remind us of the P'tridte, or 'Tits; lhat no one has yet, I believe, removed them from anong the true Sylvian birds, nor shall I do so in the present work. England is tenanted by two species, which, with one or two others, are all that are known in the Old World; in the new prortion of the globe there may be as many more. In disposition they are as tame as they are sprightly and pleasing in their actions. They suspend a neat hammock-shaped nest beneath the branches uf tir or othere trees. 'Thar egoss are numerous; and the progeny soon ecequire the plumage of the adult. 
120. Regulus cristatus Golden-Crested Wren.

A native of Europe, and doubtless other eountries to the south and castward. With us it is a resident species, and frequents aliko the three lingdoms.

\section{Regulus igicapilius . . . . Tol, II. Pl. LXX. Fine-cristed Wren.}

Tery generally dispersed over the continent of linrope and North Africa; it is purely an accidental visitant to Britain.

\section{Genus Fichoul..}

$\Lambda$ form which appears to be intermediate between the Willow Wrens and Sedge-birds.

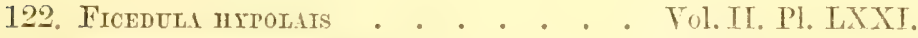 \\ Yellow-Browed Warbler.}

An accidental visitor to England :me Ireland; armmon in I[oll:and and other parts of Europe and North Africa, from which latter country it migrates north in spring, filling the drrarf woods and osier-beds of France and Holland with its melodious roicc.

\section{Family CALAIIODYTIDA.}

Ornithologists will, I um sure, agree with me in considering that the Sedge-birds constitute a rery distinct family. The numerous species, which have been divided into many genera, are very generally distributed over the older-known portion of the earth is surface. They are semiaquatic in their habits; the greater number frequent both large and small beds of sedges and other herbage growing in the vicinity of water, and feed upon insects. They are well represented in the British Islands, over which the species are generally distributed. In the present work these birds have been classed under the generie titles of Acructhluhes, Culcinoherpe, Calcmodyta, Lusciniopsis, and Locustella.

\section{Genus $\Lambda$ crocerinates,}

The members of this genus. are the largest birds of the family; and one or other of them form part of the arifaune of Europe, Asia, Africa, and Australia. 
123. Acroceriatud turdordes ..... . Vol. II. Pl. LXXII. T'inush Warbeer.

Besides inhabiting the contincut of Europe and the neighbouring countries, the 'Thrush Warbler funds its way to England, as will be seen on referene to the letterpress opposite the Plate on which the species is represented. It can only be regarded as an accidental visitor.

\section{Genus Calimomerpe.}

What has been said respecting the distribution of the members of the last genus is equally descriptive of those of the present one.

\section{Cilamoherpe arundinacea . . . . Vol. II. Pl. LXXIII. ReEd-IVArbler.}

A true migrant, arriring late in April. Nests in the lilac and other trees of the shrubberies, and in most of the gardens of the central portions of England; its nest is also frequently found among reeds and bushes orerhanging water. Besides our own country, this species frequents Central Europe and Northorn Africa.

\section{Calajioherpe palustris . . . . Vol. II. Pl. IXXXIV. MARSH-WARBLER.}

Supposed to inhabit many parts of England, and to have been often confounded with the preceding; said to arrive at the same time and to be more exclusively aquatic in its habits. Is considered always to have lighter-coloured legs and to present other, minor differences, which may be more easily seen by consulting the respectivo Plates than by the most minute description. Should it ultimately prove that the $C$. palustris is found here, it must le regarded as a regular summer visitant.

\section{Genus Cataxonyta.}

The monhers of this senus are smaller in size than the Calumoheiper", and are less uniform in the colouring of their plumage. The sitnations affected by both are identical, reeds and aquatic herbage being apparently necessary to their existenco; at all erents it in such situations that they pour forth their querulous songs both by day and by night. The Calanodyte are very generally distributed over the temperate portions of Europe, Africa, and Asia.

\section{Catanodyta phingmits . . . . Vol, II. Pl. LXXY. \\ Sedge-Warbler, or Chat.}

A bird of the summer, which arrives early in May and spreads itsclf over Fingland and Ireland, but not, according to Sir William Jardine and Ancgillivray, visiting scotland. After breeding, it departs again to Morocco or some other part of Afriea. 


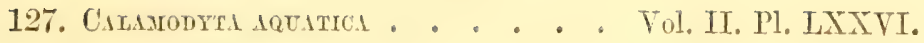
Aquatrc Warbler.

Somewhat rare in Central and Southern Europe. IIts heen lilled two or three times in England, where it must be regarded meruly as an accidental visitor.

\section{Genus Lusciniorsis.}

According to Mr. Gray's ' Hand-list of Birds' two gencric titles have been proposed by Bonaparte for the single known species of this form, riz. Pseudolusciniu and Lusciniopsis; the latter term has been employed in the present rork.

128. Luscrniopsts luscinioidess . . . Vol. II. Pl. IXXYVII. Savi's WARBLER.

Has many times been killed in England, where, however, it must be considered a rare risitant, and principally to the castern counties.

\section{Genus Locusteli.}

About fire species of this genus are known; of these one or other frequent Central and Southern Lurope, Asia, Siberia, and ('hinit.

129. Locustelit avrout . • . . . Vol. II. Pl. LXXVIII. Grasshopper Warbler.

A yearly summer visitant to England, some parts of Scotland, and Irelaud, in all of which comntries it breeds, and afterwards stealthily departs southwards in autumn. 
Family MOTACILLID E.

The Motacillite are among the most graceful of birds, and, from thoir faniliarity, tameness of disposition, and the sprightliness of their actions, are great favourites with every one who lives in the country. They have been judiciously separated into two distinct sroups, the Pied and the Yellow Wagtails, the generic term Motacilla being retained for the former, and that of Budytes for the latter. There is also another form, to which the term Culobutes has been applied; of this only one or two species have yet been discovered; of the other genera many are known. All, both Pied and Yellow, are strictly confined to the Old World, more particularly its northern portions.

\section{Gonus Motacilla.}

Two species of this furm inhabit Britain-one of which is resident, the other migratory; in India there are three or four; and in China and Japan we meet with as many more. Their natural province is the ground; but they readily perch on the branches of trees.

130. Motacilin Yarmelit . . . . . . Vol. III. Pl. I. Pied Wagtail.

A resident species in the three kingdoms, breeds freely in the neighbourhood of dwellings, and is one of the foster-parents of the joung Cuckoo.

131. Motacllet alBd • . . . . . . Vol. III. Pl. II.

White Wigitir.

$\Lambda$ common migrant on the continent of Europe, but only a rare straggler in Britim, in various parts of which it has becn seen and taken.

\section{Genus Bunytes.}

'The Ycllow Wagtails, as already stated, frequent the same countries as the l'ied, and are equally numerous in species. Of the three pertaining to the British avifauna, one is a constant spring visitor, the other two occur but seldom.

132. Budites Rsyi . . . . . . . Vol. III. Pl. III. Yellow Wagtats.

Arrives in $A$ pril, spreads orer omr fields and meadors, breeds, and returns to dfrica for the winter. Gencrally distributed orer the thece kingdoms. 
133. Budytes flata

Grey-meaded Wagtail.

$\Lambda$ common bird on the Continent, but so rare with us that it can only be regarded as an accidental visitor.

134. Budytes cinereochpilid . . . . . Vol. III. Pl. V. Gret-capped Wagtam.

$\Lambda$ bird which passes from Africa, by way of Malta, through Central Europe to breed on the Dorrefjeld and other northern parts of this quarter of the globe. Has been killed only once or twice in England, and consequently is only an accidental risitor.

\section{Genus Calobates.}

This peculiar form of Wagtail is more elegant in appearance than the members of either of the two preceding genera; its legs are shorter, and its tail longer; in colour it closely assimilates to the members of the genus Budytes. While the Motucille are circumscribed in the range of their area, the Culdrates sulpturea is found at one scason or another in nearly erery portion of the Old World, Australia and New Zealand excepted.

135. Chlonltes sturitres (Summer plumage). Tol. III. 1'I. VI.

Grey Wagtalu.

(Winter plumage). Vol. III. Pl. VII.

$A$ resident in the three kingdoms. Evinces a preference for mountainous districts. Breeds in May, constructing, like the others, a cup-shaped nest, and laying four or five eggs.

\section{Family ANTHIDA.}

\section{Pipits.}

We hare here a group of birds which are more generally spread than the Wagtails, intsmuch as they are diffused over both divisions of the globe, but which are far less numerous in the older portion than the new. Like most other large groups they have been divided and subdivided into mnny genera; those frequenting England I havo retained under the old genus Anthus, and commence with one of tho finest known species.

\section{Axthus Richardi . . . . . . Vol. III. Pl. VIII. \\ Richard's Pipit.}

An accidental risitant to the British Islands, where it is generally seen in winter and spring. The other countries frequented by it are Continental Lurope, India, ('hina, and in fact the whole of the temperate regions of the old World. 
137. Anthus chipestris . . . . . . Vol. III. Pl. IX. Thwny Proit.

Common in the champagne parts of France and other portions of Central Europe. Has been killed in Fingland, and may therefore be regarded as forming part of our avifunna but its visits must be considered purely accidental.

138. Axtmus obscurus . . , . . . . Vol. III. Pl. X.

Rock-Pipir.

A stationary species, frequenting the shores and rocky parts of Britain-sparsely in Norfolls, but plentifnlly in Western Scotland and all the westem islands, including the Outer Hebrides, Nonach Isles, IIaskar Rocks, and St. Kilda-keoping strictly to the scamargin $(R$, Gray).

139. Artiós spivoletti . . . . . . Vol. III, Pl. XI. Vinous Pipit.

$A$ bird of France and the sonthern and castern parts of Europe. Although it has been killed on our coast many times, it must be considered an uncertain and accidental risitor.

\section{Anthus Ludovicianus.}

See the remarks respecting this species in my account of the Vinous Pipit (Anthus spinoletta).

141. Antilus cervinus . . . . . . Vol. III. Pl. XII.

Red-tirroaten Pipit.

Mr. Irarting' has recorded, in the 'Ficld' for the 26 th of August 1871 , the oceurrence of two examples of this bird in our islandsone at Unst in Shetland on the 4th of May 1854 (now in the collection of $\mathrm{Mr}$. Bond), and another in september of the same yeatr at Freshwater in the Isle of Wight.

142. Anthos pratiesis . . . . . Vol. III. Pl, XIII.

Mranow-Prpit or Tithari.

A truly resident species, breeding in all the moorland counties of the three lingdoms, often the foster-parent of the young Cuclioo in this and the other Enropean conntries in which it is found. $\Lambda$ large race of Mendow-Pipits arrive on our south const in spring, and, it is beheved, spread themselves orer the ecntral and perhaps the northern portions of the country.

143. Antrus Aiboreus . . . . . . Tol. IIT. Pl. XIV. Thee-Pipit.

A summer migrant to England and Scotland, but "not," says Thompson, "satiffectorily known as an hrish species;" arrires in spring, and departs in September. 


\section{Family ALAUDIDA.}

The Larks constitute a very large family of birdis, and are perhaps less understood than any other group in the whole runge of oruithology. Those species which frequent Britain are arranged in tho genera Alauda, Gulevitu, Otocoris, Irelanocoryphe, and Calumeliella. They are chiefly inhabitants of the Old World. Of the genus Alemele, under which term all that were known when Linneus wrote were included, our well-known Sky-Lark is a typical example. In America these birds are but feebly represented.

\section{Genus Alituda.}

\section{Alacd aryensis . . . . . . Tol. III. Pl. XY.} Skr-Lark.

A strictly resident species in Britain, the number's of which are greatly increased by arrivals from Scandinavia in antumu, the whole forming immense flocks in the winter season. This species is also widely dispersed over Central and Southern Europe; and its rauge may even extend further in those directions. In the preceding portion of this introduction I have mentioned the great destruction of small birds which occasionally takes place from the severity of the weather, in further confirmation of which I may here give a passage from a note receired by me from John St. Lubyn, Eirq., of Pendeen, in Cornwall, dated Januiry 15, 1867:- "Owing to tho severity of the cold, Larks and other small hirds are beginuing to die rapidly of starration, judging from the number my children pick up."

\section{Aladd arborel . . . . . . Vol. III. Pl. XVI. Wood-Lark.}

$\Lambda$ cheery little songster, very local in its habitat, breeds in many of the English counties; supposed to migrate from us to the southward in the winter; but Mr. Blake Finox states that it is abundant at that season in the county of Dublin, and also that it breeds there. It is about as numerous in Scotlind as it is in England; find $\mathrm{Mr}$. IIarting states it has been fomel as fin north as the Orlaney Island.

\section{Genus G.jerita.}

14. Gilmime cristate . . . . . Vol. IIl. Pl. Xtil. Crested L.irk.

A bird of France and many other parts of the Luropean continent, and even of other more distant countrics. Although common on the roads between Calais and Boulogne, it seldom crosses the Chamel to pay Albion's shores a visit; here, indeed, it is so scarce that it must be enumerated among our accidental visitors. 
Genus Otoconis.

Of this omamental section of the Larks there are about ten known species, six or seven inhabiting the Old World, and three the New. All are more or less ornamented with small pencilled plumes springing from abore the eye, and hare much of their plumage suffused with yellow and pinky brown. Their head quarters are eastern Europe, Palestine, Atghanistan, the Altai, and the highlands of Asia generally.

147. Octocoris atpestris . . . . . Vol. III. Pl. XVIII. SIORE-LARK.

This bird has appeared here so frequently of late that it may almost be termed a regular winter visitant. Lord Lilford has recorded, in the 'Zoologist' for 1852, an instance of its nesting in Devonshire.

\section{Genus Jeranocorypits.}

A little group of thick-billed Larks, comprising five or six species; almost exclusively inhabit the central and eastern regions of $A$ sia.

148. Muta focorypha calandra . . . . Tol. III. Pl. XIX. Calandra Latik.

$\Lambda$ common species in most of the champaign parts of C'entral and Southern Europe, but a purely accidental visitor to England, two instances only of its occurrence here being on record, both in Devonshire.

149. Melanocorypila leucoptera . . . . Vol. III. Pl. XX. WHITE-WINGED LARK.

The native country of this bird is Siberia and the eastern portions of Europe. In a single instance only has it been lilled in England, for the particulars of which see the letterpress opposite the plate.

\section{Genus Calandrella.}

150. Calandrelca brachydactyla . . . Vol. III. Pl. XXI. Short-tomd Lirk.

A native of Central and Southern Europe, India, and China. Only four or five instances of its haring been killed in England have been placed on record; consequently it must be regarded as purely an accidental visitant.

\section{Family EMBERIZIDA.}

The members of this great group of birds extend orer Europe, Asia, and $A$ frica, to which sections of the globe they appear to tre confined, inasmuch as no true bunting has yet been discovered in 
Ameriea, Anstralia, New Zealand, or, I believe, the islands of the Eastern archipelago. The numerous species of which the family is composed are divisible into many genern; and the ten species reeognized as inhabiting Britain have been divided into six or seven. The food of all, both of those which frequent our islands and of those found in other countries, is of a mixed character, seeds of varions kinds constituting its main portion; but insects and their larve are largely partaken of, and probably form at first the sole nourishment of the young.

\section{Genus Emperizı.}

151. Embertza ctrrinelda . . . . . Tol. III. Pl. XXII.

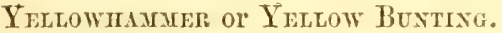

Tery generally dispersed over the three kingdoms; breeds and rears its young between spring and midsummer. British specimens differ considerably in the colouring of their plumage, and are very much less in size than continental examples.

152. Embertza cirtus . . . . . Vol. III. Pl. XXIIT.

Cirl Bunting.

A resident, but somewhat local ; breeds in most of our sonthern counties, particularly in chalky districts, and ammually as near to London as Cookham, in Berkshire; very searee in Scotland, and never seen in Ireland.

158. Embertza rustica . . . . . Vol. III. Pl. XXIV. Rustic Buntrig.

The native habitat of this bird is the eastern part of lurope and the neighbouring countries. Has been killed near Brighton, for the particulars of which circumstance see 'The Ilis' for lscis!, p. 128, and the letterpress facing the figure in the present work.

154. Eybertza pusilta . . . . . . Vol. III. Pl. XXV.

Dwatif Buxtrat:

Inhabits Northern and Eastern Europe, Siberia, China, and the Itimalaya Mountains. Has been once lilled in England, vidr ' [bis,' 1865, p. 113, and the accormt opposite the present plate.

\section{Genus Crithoritagi.}

\section{Critiopitagi mitimia}

Tol. III. PI. XXVT. Common Bunting.

A truly British species, which is also found in Central and Sonthern Europe, Northern Afriea, Asia Ninor, and Persil. Breeds in our three kingrloms ; is solitary in its habit, being generally seeu sitting 
alone on the topmost trig of a hedge-row. The sole representative of its genus, or genera ; for it has hat no less than five generie terms npplied to it-Emberiza, Spinus, Cynchremes, Miliare, and Crithophaga.

\section{Genus Glicispixi.}

Comprising about six or seren species inhabiting Emope, Asia, and Africa.

156. Glycispina motrtulast . . . . Vol. III. Pl. XXVII. Ortolan Bunting.

A birk which ranges very extensively over Lurope, being common from the shores of the Mediterranean to the Dorrefjeld in Norway; in the latter comtry it breeds in abundance. It is but an accidental visitor to Englund, has once only, I believe, been liblled in Scotland, and never in Ireland.

Genus Euspizı.

157. Euspiza melanocephital . . . Vol. IIT. Pl. XXVIII. Br.ich-He.ided Bentixg.

Common in Eastern Europe, Porsia, and Western India. The male is a beautiful showy bird, the female more plainly dressed, as will be seen on reference to my plate, which represents an individual of the latter sex, said to have been killed on Brighton race-course on the 3rd of November, 1868.

\section{Genus Sctianicota.}

The nembers of this marsh-loving section of the Buntings are about three in number, all inhabitants of Europe and the countries to the eastward of it.

158. Schemtcotil ardndtacea - . . Vol. III. Pl. XXIX.

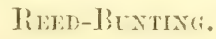

A resident and generally distributed species; breeds in the Thames aits and in the osier-beds of other rivers.

\section{Genus Centropmanes.}

Comprises about fire species of rery interesting mountain-loving lirrls, mostly American, and always in high northem latitudes, the species inhabiting Lapland occasionally paying the British Islands a visit.

159. Centrotillates lipponica . . . . Vol. IIt. Pl. XXX. I.APLiNo Btxtixg.

A rather frequent winter visitant, often canght in the clap-nets of the bird-catchers. 
Genus Plectrommines.

$\Lambda$ genus composed of the single species known by the trivial names of Snow-Bunting and Snowflake.

160. Plectrophlnes nifalis . . . Tol. IIT. Pl. XXXI.

SNow-Bunting or Sxowflate.

'This rery interesting bird is an autumnal and winter visitant to the British Islands. Its summer quarters are the countries near to and, not unfequently, within the aretic circle. It breeds in Lapland, aud probably in suitable situations in all other countries of a similar latitude round the globe.

\section{Genus Zoxotriomi.}

A purcly Imerican form, comprising abont twelre known species, one of which has strayed across the Atlintic to the British Islinds.

\section{ZONOTRTCHIA ALBECOLLTS.}

White-throated Sparrow of American authors.

" $\Lambda$ female specimen of this hird," says \Гx. R. Gray, in his "Birds of Western Scotland," "was shot near the Broadhill, on Aberdeen liuks, on the 17th of Argust, 1S67." This specimen was sulsequently sent to Professor Newton for exhibition at the Meeting of the Zoological Society of London on the 27th Jamuars, 1870. More recently a second example, taken near Brighton, was cxhibited at a Mecting of the same Society loy George Dawson Rowley, Esc].

\section{Family FRINGILLIDÆ.}

The Finches are a family of lirds comprising a larger number of members than the Buntings and the Larks, and are eren more widely dispersed orer the earth's surfuee than those of any other groul. In a work limited to the birds of our own islands, it would be out of place to give an enumeration of even the genera into which thes have been separated; and I thercfore confine my remarks to such forms as are found in Britain.

\section{Subfamily FRINGTLLIN.E.}

\section{Genus Pisser.}

The true Sparrows are principally confined to the northern parts of the Old World. Asia is inhabited by sereral species, and Europe by four or five, two of which frequent the British Islands.

162. Passer domesticus . . . . . . Vol. III. Pl. XXXII. Common or House-Sparrotw.

Distributed generally, but somewhat scaree in the northern parts 
of Scotland. A bird whose faults are few in number, and respecting which a sad mistake was made when certain parochial authorities placed a price upon its head; for the good it effects in spring loy the capture of insects far outreighs the value of the fer grains of corn in a pulpy state which it occasionally takes.

163. Passer montanes

Vol. IIT. P1. XXXIII. 'Tree-Sparrow.

A local species, and consequently much less widely diffused over the British Islands than the preceding: not so, however, with regard to its general distribution; for it is as common at Shanghai and other parts of China as it is in Europe. Both in Scotland and Ireland it is local and rare.

\section{Genus Fringthla.}

The members of this genus of pretty birds as now restricted are but few in number. They all inhabit the northern and western portions of the Old World. England is frequented by two species.

\section{Fringill. cellebs . . . . . Vol. III. Pl. XXXIV. \\ Cirifinter.}

A bird of general distribution over the three kingdoms; but Mr. Augustus Smith tells me that in the Seilly Islands it only appears in winter.

165. Frivgilda yontifringtela . . . Vol. III. Pl. XXXV. Brimale-Fivem.

A true winter risitant; gregarious. Arrives in autumn, probably from Norway and Lapland, where the process of reproduction la:13 been accomplished.

\section{Genus Carduelis.}

A limited genus, of which our beautiful Goldfinch is the type, and whose only associates are the $C$. canierps of the Himalayas and the $C$. orientatis of Central India.

166. Cardelis heegins . . . . . . Tol. III. Pl. XXXVt.

Golderycir.

A resident species, common and almost universally distributed over the British Islands, and equally plentiful on the neighbouring continent.

\section{Genus Girisomitris.}

Of this genus one species inhabits the Old World, and some seren or eight are distributed over America, from California to Chili. 
167. Chrmysomitris spinds

\section{Siskin.}

As regards this beautiful little bird, Scotland has the advantage over England; for it regularly breeds there, while with us it is a winter visitant; and in Ireland it is only seen at that season.

\section{Genus Serinus.}

A small group of about three species, one of which, the Common Canary, is the type. They inbabit Europe, Palestine, Madeira, and the Canary Islands.

168. Serindes hortulanus . . . . Vol. III. Pl. XXXVIII.

\section{Serin Fincir.}

Has been several times killed in England. Mr. Harting enumerates ten instances of its occurrence herein, viz. :-five at or near Brighton; one in Hampshire; one in Somerset; one in Sussex; one near London; and one, locality not noted.

\section{Genus Ligurivus.}

Four species of this form, to which the generic names of Ligurinus, Chloris, and Chlorospiza have been applied, are all natives of Europe and Asia. Japan is tenanted by one, China by another, Persia by a third, while Europe is the home of the type, our well-known Greenfinch.

169. Ligurinus cirloris . . . . . Vol. III. Pl. XXXTX.

\section{Greenfinch.}

A resident species in Britain, over which, says Mrr. Harting " it is generally distributed, even to the Outer Hebrides, where it is found in North Uist and Harris and the Orkueys." On the continent of Europe it is almost equally dispersed : and I have a specimen from Erzeroum, in Persia; but I must mention that, although a fully adult male, it is of smaller size than examples killed in England.

\section{Genus Coccothraustes.}

I believe the bird inhabiting Europe to be the only representative of its genus; for I very much question whether the Japan bird is really different.

170. Coccothraustes vulgaris . . . . . Vol, III. Pl. XL. HATFINCH.

This bird, which has become more plentiful of late jears, is a permanent resident in England. In Sicotland it is more scarce, and is probably confined to its southern and eastern provinces. In Ireland it is only occasionally found. 


\section{Subfamily. PYRRHULINE.}

The well-known Bullfinch of the British Islands is placed at the head of this subfamily, of which there are about seven species, inhabiting various parts of the world. The countries where one or other of them are found are Europe, Cashmere, the Himalayan regions, Bhotan, Japan, and the Azores.

\section{Genus Pyrrhola.}

171. Pyrmitula vulgaras . . . . . Vol. III. Pl. Xli. BULlfinch.

172. Prrritula vulgaris . . . . . . Vol. III. Pl. XliI. Bullfincir (joung).

Very generally dispersed orer England, Scotland, and Ireland, and, as it brecds therein, must be regarded as a stationary species.

\section{Genus Carpodacus.}

Although the propriety of placing the Scarlet Bullfinch (Curpoducus erythimus) and the Pine-Grosbeak (Pinicole enucleator) in the subfamily Pyrrhulince may be questioned, it is certainly the best situation I can assign to them in the British avifauna.

Of the genus Carpodacus about nine species are known, some of which inhabit America.

173. Carpodacus erythrinds • . . . Vol, III. Pl. XliII. Scarlet BUllfincri.

A native of North-eastern Europe and Asia, only two instances of the occurrence of which in this country are on record-one near Brighton, and another in Caen Wood, Hampstead, Middlesex.

\section{Genus Pinicola.}

Two or three rery distinct species of Pine-Grosbeaks are now known, one of which frequents Norway, Lapland, and Russia; the other, $P$. canadensis, is as exclusively an inlabitant of the northern portions of America, Canada, and Hudson's Bay.

17t. Pinicola enucleator . . . . . Vol, III. Pl. XliV.

Pine-Grosbeak.

A very rare and inconstant risitor to the British Islands; still many instances are on record of its having been killed here.

\section{Subfamily LOXIANX.}

As the great forests of conifers are peculiar to the northern portions of the globe, so also are the members of the present remarkable 
group of birds, whose singularly constructed bills are especially adapted for extracting the seeds from the cones of these trees. Six or seven species are all that are known: and these are spread over the Old World, from Europe, throughout Northern Asia, to Japau, and in the New World from the Aretic regions to Mexico. 'T'wo species come to Britain at uncertain intervals to breed.

\section{Genus Loxia.}

175. Loxta curvirostra . . . . . Vol. III. Pl. XLV. Common Ćrossbill.

A pretty regular risitor, if not a stationary apecies, in scotland, where it sometimes breeds.

176. Loxia pityopsimtacus . . . . . Vol. III. Pl. XLVI. Parrot Crosstill.

Has occurred many times in Britain, and maty have remained and bred; but if so, no authentic instances of such an oceurrence are on record.

177. Loxila bifasciata . . . . . Tol. Hit. Pl. Allvil.

White-tvinged Crossbill.

Ilab. Northern Europe and Asia.

Many instances are on record of this bird having been killed in the central portion of Furope; and it hus frepuently oceured in Englimel, and twice in Ireland.

178. Loxia leucopteri . . . . . Vol. III. Pl. XLVIII. american White-winged Crossmill.

Inhabits North America, and is of rare occurrence in England. Besides the specimen alluded to in my account of the species as having been found on the shore at Exmunth, Mr. Harting mentions other instances of its appearance in England, and Mr. Gray one near Jedburgh in Scotland.

\section{Genus Lisota.}

The generic term Linotu, proposed by Bonaparte, and that of Linaria, by Bechstein, appear to have been both applied to this small group of Fringilline birds, the nember's of which are principally, if not solely, confined to the northern parts of Lurope and Asia.

179. Livoti catyabita . . . . . . Vol. III. Pl. XlLX. Linnet.

Resident in and rery generally distribated over brituin; partially migrates south on the approach of winter. 
180. Linota montidu

\section{'T'wite or Modntain-Linnet.}

A winter visitant to England, remaining to breed in its northern counties, and also in Scotland. Thompson states that it is resident from the north to the south of Ireland.

\section{Genus Agrornus.}

The nembers of this genus, familiarly known by the name of Redpoles, are inlubitants of the boreal regious of both the Old and the New World-some of them affecting very high lititudes, and even breeding within the arctic circle.

181. Egiotuls lindris . . . . . . Tol. III. Pl. LI.

\section{Mralt Redpole.}

The native countries of this hird are Norway and Lapland, whence it migrates to England and scotland in antumn and winter. Is said not to have been seen in Ireland; but it certainly must occur there, as it also does in America.

182. Agiothus rufescens . . . . . . Vol. III. Pl. LII.

\section{Lesser ReDpole.}

A stationary species in Britain; winters in all our southern counties, and retires to the northern parts of England and Scotland for the purpose of breeding: according to Thompson it also nests in Ireland. With respect to the range of this bird, see Professor Newton's remarks in the 'Zoologist' for 1870, p. 2223.

\section{Family STURNID Æ.}

The Starlings and Pastors constitute a very natural group of birds which chiefly inhabit Asia, Africa, and Europe. Two, belonging to different genera, form part of the British fauna.

\section{Genus Sturnus.}

The true Starlings are few in number, only six species being enumerated in the most recently compiled list. They are all denizens of the northern parts of the Old World, and are found in Europe, Asia Minor, Persia, Afghanistan, and China.

183. Sturnus vulgaris . . . . . . Vol. III. Pl. LIII. StARLING.

184. Sturnus vulgaris . . . . . . Vol. III. Pl. LiV. Starling (young).

A resident species. Breeds in the three lingdoms, and is gregarious in autumn, winter, and spring. 
Genus Pistor.

The birds of this form, which are almost peculiar to the European. African, and Isiatic portions of the globe, are at once interesting and useful, -interesting on account of their beauty, and useful from the good they effect in the countries they frequent by the destruetion of the locusts and other insects and theic larve, upon which they feed.

185. Pastor rosets . . . . . . . . Tol. III. Pl. I. Rose-coloured Pastop.

186. Pastor rosegs - . . . . . . Vol. III. Pl. LVI. Rose-coloured Pastor (young).

A beautiful but unusually-coloured bird, which is very plentiful. in Eastern Europe, Asia Minor, and Western India. It is merely an accidental visitor to England, Scotland, and Ireland.

\section{Family ICTERID.E.}

This is a purely American family, comprising considerably more than a hundred species, which are spread over the contincut of America and the approximate islands. Two of them have from time to time wandered far from their native homes and sought a haven. in the British Islands.

\section{Genus Agruidus.}

Of this section of Icterine birds about fire species are known, the habitats of which are almost exchusively confined to the temperute and northern parts of the American continent.

187. Agetatus phaniceus.

Red-winged: Starling.

Nine instances are on record of the occurrence of this species in Britain, namely seven in England and two in Seotland. The carliest of these appears to be the one mentioned as having been taken near London, by Albin, in his 'History of British Birds,' puhlished in 1731-38, after which the bird seems to have remained unnoticed until the year 1843 , between which date and $1 \$ 71$ eight others are described as having been met with in various parts of the country. The late Mr. Yarrell figured this transatlantic species in the supplement to his 'History of British Birds,' to which work, as woll as those of Wilson and Audubon, I must refer my readers for its history: for, as I do not consider the bied pertains to our fauna, I have not included a figure of it in this work.

\section{Genus Stornelia.}

A peculiar group of grass-loving birds, strictly confined to America, orer which country the five known species are distributed. 
188. Sturitali Lodofrctana.

American Meadow-Starling.

Threc instarces of the occurrence of this bird in England have been recorded-Mr. Solater mentioning, in 'The Ibis' for 1861, one that had been shot at Thrandeston, in Nuffolk, and another seen at South Walsham, in Norfolk, and Mr. Lloyd the third, in the 'Field' for March L 61 , as haring been obtained near Cheltenham many years ago; this latter specimen was seen and rerified by Mr. Harting.

This species, like the preceding, being purcly American, I have not included a figure of it in my work. For all particulars respecting it, see the works of. Wilson and Audubon, and Mr. Sclater's paper in 'The Ibis' above referred to.

\section{Family CORVID E.}

The members of this family, comprising some of the rery largest of the Insessorial hirds, are distinguished by sereral characteristies, and are divided into many genera. The Crows, the Daws, the Rooks, and the Choughs may be regarded as the more typical forms, and the Jays. Pies, and Nutcrackers as the more aberrant; still they, with many other genera, are placed in this large and all but unirersally spread family.

\section{Genus Corros.}

One or other of the true Crows are dispersed over all parts of the glohe, with the exception of the sonthern portion of Ameriea, New Zealand, and Polynesia, where none are to be found. Structurally they are considered by many writers to be among the most perfectly formed birds which exist, their organization enabling them to fly throngh the air, pereh on the branches of trees, and walk over the surface of the ground with equal facility, and the muscles of their throats permitting them to utter connerted sentences scarcely equalled by the members of any other group of birds.

189. Corves corax.

Vol. III. Pl. LVII.

Ravin.

$\Lambda$ resident species, generally dispersed over the three kingdomsplentiful in the north, more searce in the sonth, where its great size and ruestionable habits procure it many enemies. Besides Britain, the northern portion of Europe, Asia, and America are countries which may include it in their avifaunas.

190. Corvus corone . . . . . . . Vol. IIT. Pl. LVIII.

Carrion-Crow.

A resident species, generally diffused orer the three lingeloms: is also found in most parts of Europe. Jerdom, on the authorits of 
Dr. Adams, assigns it a place in the fauna of Tudia, and Swinhoe in that of China; while it frequents at least the northern portion of Africa.

191. Corvos cornix . . . . . . Vol. III. Pl. LIX. Hooded Crow.

A resident species in the three lingdoms: breeds in Seotland and Ireland, and but very rarely in England; is to be met with in many parts of the European continent, both north and south : and is particularly common in Palestine and Egypt, where it is often the foster-parent of the young of the Great Spotted Cuckoo (Oxylophus glandarius).

\section{Corvus Frugilegus}

Vol. III. Pl. LX. Rоoк.

I have retained this bird in the genus Comess many other authors hare adopted Lesson's genus Frmilyzus, and Prof. Kaup's term of Tryphumocorax for it and its immediate allies. Tulike the Crows the Rooks are gregarious aud associate in immense flocks; they differ from them also in the structure of their bills, the peeuliar form of which seems adapted for some special purpose, perhaps for the procuration of a particular kind of food, such as large mudergrounddeposited larra of insects, grain, and tuberous roots, as the husbandman well knows to his cost. The rook is even still more omnirorous; for it will not refuse worms, crustaceans, or carrion thrown up by the wares of the sea. Generally dispersed over England, Scotland, and Ireland. Rooks are only found in a limited portion of the Old World.

193. Corvus movenula . . . . . . Vol. III. Pl. LXI.

\section{JACKDAW.}

Eren this indigenous species and its sereral near allies have been subjected to a generie separation from the genus Corves, the term Lyces haring been bestowed upon it by Boie, the specific names of the others being collaris for the Macedonian bird, damrious for the Daurian and Chinese species, neglectus for that inhabiting Japan. All are of small size when compared with the true Crows; they affect different situations for the purpose of breeding, resorting. to rocks, old towers, and holes in the ground rather than to the trees. They are strictly denizens of the Old World.

\section{Genus Fregilus.}

The Red-legged Crows differ considerably from any of the species abore noticed, and are certainly entitled to a separite gereric alpellation, and accorlingly have received three or four. The genus comprises but few species, only two being recognized, namely the 
birl inhabiting Europe, F. graculus, and the F. Thimalayensis of the Himalayas.

\section{Fregrlus graculus . . . . . . Vol. III. Pl. LXII. Chotgit.}

This truly indigenous species is spread orer the three kingdoms, but is more rare in Scotland; breeds in the rocks on the sea-shore, in company with Cormorants, Gulls, Puffins, and Guillemots. Found also in many of the hilly and Alpine parts of the European continent and in North Africa.

\section{Genus PicA.}

A rery elegant group of lirds, whether seen among the branches of trees or on the ground. Their powers of flight are not so great as those of the preceding members of the family. All are similarly coloured, black, white, and green with bronzy reflections being the prevailing tints. Two species inhabit the northern portions of America ; one is peculiar to Africa ; the remainder frequent Europe, Asia. and Japan,-each being confined to its own limited area, bejond which it is seldom found.

195. Pica caddata

Vol. III. PI. LXIII.

\section{MagPif.}

An ormamental and stationary species, inhabiting most of the counties of England, Scotland, and Ireland.

\section{Genus Garrulus.}

If we restrict this genus to the lirds of the Old-World form, of which our familiar Jay is a typical example, it will be found to consist of nine or ten species, and, as is the case with the Magpies, that Europe and Asia are their head quarters ; at the same time North Africa is not destitute of its own peculiar Jay. Structurally they are especially adapted for frequenting the branches of trees, and not for the ground, although they are often seen there. They are a sly, crafty race; and much obloquy attaches to them for their habit of pilfering the eggs and the young of other birds ; fruits and berries, insects, snails, worms, and other of the lower animals afforded by forests constitute, however, theix chief food.

196. Garulus glandarius . . . . . Vol. III. Pl. LXIV. JAY.

A resident species, more common in England than in Scotland. Thompson says it is only indigenous in the sonthern parts of Ireland. Mr. J. I. Gurney considers that an autumnal migration takes place to our eastern coasts. On the continent of Europe the Jay is 
generally dispersed wherever the country is suited to its habits. I have a specimen killed in Spain which does not differ from examples obtained in this country.

\section{Genus Nuctfraga.}

Only three or four species of Nutcracker hare ret been characterized. They are inhabitants of Europe and Asia.

\section{Nucifraga caryocatactes . . . . Vol III. Pl. LXV. Nutcracker.}

198. Nucifraga caryocatactes . . . Nol. III. Pl. I. VVI. Nutcracker (young).

Indigenous in most of the mountainous and woody countries of Europe; breeds abundantly in Switzerlaud. In England it can only be considered an accidental visitor. Mr. Harting, in his ' Handbook of British Birds,' enumerates about twenty instances of its oceurrence here from the date Pennant wrote, 1753 , to within a fer years of the present time, 1872 ; still these visits ean only be regarded as accidental.

\section{Family CUCULIDAE.}

The members of this great family of birds are rendered especially remarkable and interesting from the circumstance of the greater number of them having parasitic habits. The entire family comprises about two hundred species, which are subdirided into several subfamilies, and many genera. They are universally dispersed over the temperate portions of the globe; but not more than a fourth part of the whole number are found in America.

\section{Genus Cuculos.}

The members of this genus, restricted to the true Cuckoos, are tolerably numerous. One species inhabits Europe; and there are others in India, China, Jara, Sumatra, the islands of the Indian archipelago, and Australia; they are also well represented in Africa.

199. Cuculus canorus . . . . . Vol. III. Pl. LXVII.

\section{Comaron Cuckoo.}

200. Cuculus canorus . . . . . Vol. III. Pl. LXVIII. Comiron Cuckoo (young).

The common Cuckoo is a true migrant, coming to us from the south in May, and departing again in September, the young being frequently left behind to a later period of the year. 
I now find that the opinion rentured in my account of this species as to the impossibility of the young Cuckoo ejecting the young of its foster-parents at the early age of three or four days is erroneous; for a lady of undoubted veracity and considerable ability as an observer of nature and as an artist, has actually seen the act performed, and has illustrated her statement of the fact by a sketch taken at the time, a tracing of which has been lindly sent to me by the Duke of Areyll, and I have considered it of sufficient interest to reproduce here in a moodcut. The sketch was accompanied by Mrs. Blackburn's acconnt of the circumstance as it came under her observation-which is here given from No. 124 of 'Nature,' a weekly illustrated journal of science.

"Several well-known naturalists who have seen my sketch from life of the young Cuckoo ejecting the young Pipit (opposite p. 22 of the little versified tale of mine) * have expressed a wish that the details of $\mathrm{my}$ observations of the scene should be published. I therefore send you the facts, though the sketch itself seems to me to be the only important addition I have made to the admirably accurate description given by Dr. Jenner in his letter to John Hunter, which is printed in the 'Philosophical Transactions' for 1788 (vol. lxxviii. pp. 225, 226), and which I have read with pleasure since putting down my own notes.

"The nest (which we watched last June, after finding the Cuckoo's egg in it) was that of the common Meadow-Pipit (Titlark, Mosscheeper), and had two Pipit's eggs besides that of the Cuckoo. It was below a heather bush, on the declivity of a low abrupt bank on a Highland hill-side in Moidart.

"At one visit the Pipits were found to be hatched, but not the Cuckoo. At the next risit, which was after an interval of fortyeight hours, we found the young Cuckoo alone in the nest, and both the young Pipits lying down the bank, about ten inches from the margin of the nest, but quite lively after being warmed in the hand. They were replaced in the nest beside of the Cuckoo, which struggled about till it got its back under one of them, when it climbed backirards directly up the open side of the nest, and hitehed the Pipit from its back on to the edge. It then stood quite upright on its legs, which were straddled wide apart, with the claws firmly fixed halfway down the inside of the nest, among the interlacing fibres of which the nest was woven; and, stretehing its wings apart and backwards, it elbowed the Pipit fairly orer the margin so far that its struggles took it down the bank instead of back into the nest.

"After this the Cuckoo stood a minute or two, feeling back with its wings, as if to make sure that the Pipit was fairly orerboard, and then subsided into the bottom of the nest.

"As it was getting late, and the Cuckoo did not immediately set to work on the other nestling, I replaced the ejected one, and went 1872 .

* 'The Pipils,' illustrated by M[rs. Tugh Blackburn. Glasgow: Maclehose. 
home. On returning next day, both nestlings were found dead and cold, out of the nest. I replaced one of them; but the Cuckoo made no effort to get under and eject it, but settled itself contentedly on the top of it. All this I find accords accurately with Jenner's description of what he saw. But what struck me most was this: The Cuckon was perfectly maker, without a vestige of a feather, or

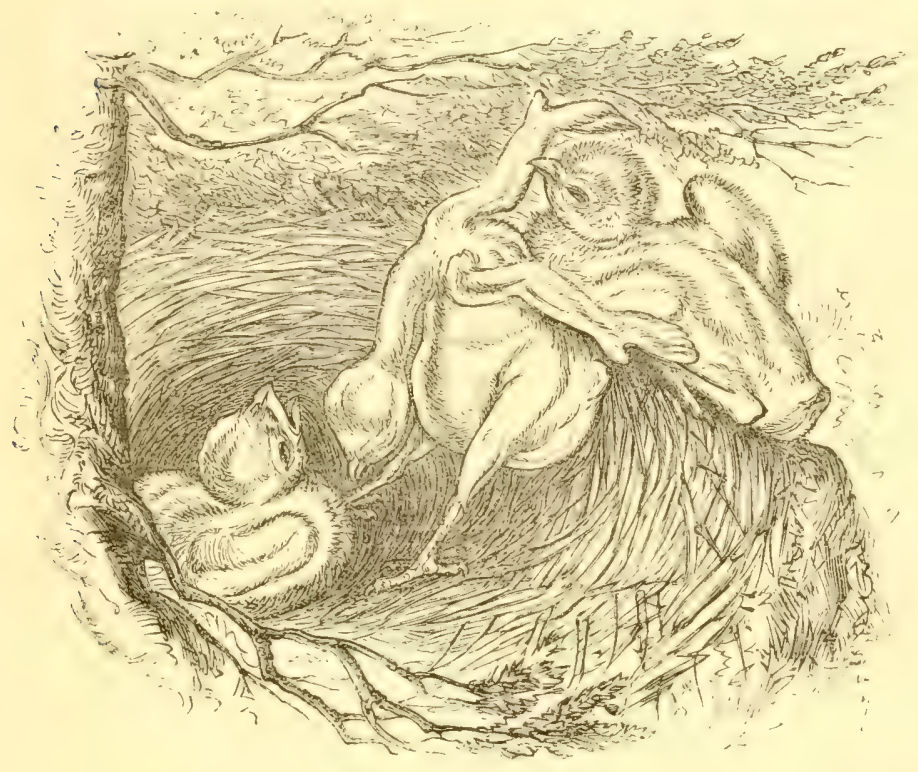

eren a hint of future feathers; its cres were not yet opened, and its neck seemed too weak to support the weight of its head. The Pipits had well-developed quills on the wings and back, and had bright ejes, partially open ; yet they seemed quite helpless under the manipulations of the Cuckoo, which looked a much less dereloped creature. the Cuckoo's legs, however, secmed vory muscular, and it appeared to feel about with its wings, which were absolutely featherless, as with hands, the 'spurious wing' (munsually large in proportion) looking like a spread-out thumb. The most singular thing of all was the direct purpose with which the blind little monster made for the open side of the nest, the only part where it could throw its burthen down the bank. I think all the spectators felt the sort of horror and awe at the apparent inardequacy of the creature's intelligence to its acts that one might have felt at seeing a toothless hag raise a ghost by an incantation. It was horribly 'uncanny' and 'grewsome." "

$\Lambda$ few words more on this subject. Mr friend Mr. Noble, of Park Place, Heuley-on-Thames, wrote to me thus on the 4 th of May. 1871: 
" Mrs. Noble told me this moruing that a Wagtail had built a nest in our dining-room balcony ; on going thither I found the nest in a coruer quite exposed, with three eggs in it, one much larger than the others; the two smaller ones were of a greenish colour with minute spots, the larger of a deeper green and more largely blotehed. Can this be a Cuckoo's?"

On Sunday, May the 21st, I saw this nest with four young birds, three lying by the side of the nest, from which they had eridently been but recently thrown, as they were plump and fresh. Allowing, therefore, that the Wagtail had laid a third egg on the 5th of May, and thirteen or fourteen days for the hatching of these birds, they must have been ejected in about three days after exclusion. On the 31 st of the same month Mr. Noble again wrote:-_The Cuckoo is nearly fledged; he rises in the nest in the most hideous way, extending his neck like a serpent."

Were we in possession of similar positive evidence of the means by which the Cuckoo's egg is deposited in the dome-shaped nest of the Wren, and in those of other birds, as we now have of those in which the young of the foster-parents are ejected, the history of the breeding-habits of this remarkable bird would be complete.

\section{Genus OxrLopHus.}

There are several species of this genus, which inhabit Africa, India, and some of the islauds to the southward. They are, I believe, all parasitic, laying their eggs in the nests of Crows, Magpies, and other large birds.

\section{Oxylophes glixdirits . . . . Tol. III. P1. LXIX.}

\section{Great Spotted Cuckoo.}

Two indiriduals of this speeies haring been killed in our islands, one in Ireland and another in Northumberland, it becomes necessary to figure it in the present work. Respecting this latter example, I received the following uote from Lord Ravensworth, Dec. 5, 18i1:-

"You will no doubt be interested to hear that a specimen of the Great Spotted Cuckoo was shot last summer, in July or August, upon the moors at Hesleyside, the noted seat of W. H. Charlton, Esq., on the banks of the North Tyne. It has been preserved, but unluckily is indifferently set up." The Rev. H. B. Tristram informs me that he handled this bird in the flesh before it had been skinned.

In Southern Europe this bird is plentiful during summer, and in North Africa it is to be seen at all times. Even the rapacious Hooded Crow does not disdain to become the foster-parent of the young of this species.

\section{Genus Coccrzos.}

Composed of a limited number of species, all American, of which two have been killed in our islands. 


\section{Coccyzus ayericands.}

Yellow-billed Cuckoo.

Five instances of the occurrence of this species with us have been recorded by Mr. Harting in his 'Handbook of British Birds'-two in Ireland, two in Wales, and one in Cornwall. A figure will be found in Yarrell's ' History of British Birds,' vol. ii. p. 210.

\section{Coccyzus ERYTHROPHTHALMUS.}

\section{Black-billed Cuckoo.}

One killed in the county Antrim, Sept. 25, 1571, see 'Zoologist, 1872 , p. 3022.

I have not considered it necessary to figure these two Anerican species, as they eertainly do not belong to our fauna.

\section{Family PICID Æ.}

With the exception of Australia, New Zealand, and Polynesia, Woodpeckers are distributed over the temperate and warmer verions of every country both of the Old and the New Wrorld. About 300 species are enumerated in the useful 'Hand-list of Birds' of the late Mr. G. R. Gray, of the British Museum. Is might naturally be supposed, much diversity of form exists among the members of so rast a body of birds, each form being especially adapted to some given purpose or locality, the boles and leafy foliage of trees, rocky parched plains and humid grassy meadows being alike resorted to by one or other of them. They are all zygodactyle in the form of their feet, although, in some cases, only a rudiment of one of the hind toes is found to exist. So far as my knowledge extends, they one and all deposit their beautiful shining white egrs in the boles of trees; but I think it probable that some few may occasionally place theirs in erevices of rocks. Their principal food consists of insects and their larva; the ground-frequenting species consume ants and their eggs in great numbers; and fruits and berries are not rejected by others. The species inhabiting Europe are about ten in number, four of which are represented in the jresent work; and $I$ here subjoin notices of the occurrence of two or three other accidental visitors from America.

\section{Subfamily PICIN E.}

\section{Genus Picus.}

Members of this truly arhoreal form are found both in the old and in the New World. 'They feed almost exclusively on insects and their larve, but probably partake of spiders also, which they search for and extract from the bark of trees. 
204. PicUs MaJoR

Vol. III. Pl. LXX.

Great Spotted Woodpecher.

A resident species. Common in England, but more rarely met with in Scotland and Ireland.

205. Picus ledconotus . . . . . . Vol. III. Pl. LXXI. WHITE-BACKED WOODPECKER.

An accidental visitor to the Hebrides.

206. PiCUS MiNoR Vol. III. PI. TXXII.

\section{Lesser Spotted Woodpecker.}

A resident species in Eugland, extremely rare, if at all to be found, in Scotland, and never occurs in Ireland.

The late Mr. Briggs, of Cookham, in Berkshire, who was a close observer of nature, and especially of our native birds, informed me just prior to his death that he had witnessed many curious actions and displays performed by this species while flitting and hovering with outspread wings around the leafy branches and crowns of high trees, apparently engaged in cipturing small insects. I deem it necessary to mention this, because we really know but little respecting the actions of even our commonest Woodpecker.

\section{Picus villosus.}

Hairy Woodpecker.

There is no doubt about this American species haring been killed several times in Britain. Latham mentions a pair from Halifax, in Yorkshire, in the collection of the then Duchess of Portland; and one was killed in 1849 at Whithy, in Yorkshire, as stated by Mr. Higgins in the 'Zoologist' for that year, 1). 2496 . This latter specimen I have examined, and have no duubi of its identity, nor of the authenticity of its occurrence. It is not figmed, because it is purely American and only an accidental visitor.

\section{Picus pubescens.}

\section{Downy Woodpecker.}

Mr. Irarting mentions the occurrence of a single example of this bird at Bloxworth, near Blandford, Dorsetshire, in 1)ecember 1836, as reported by the Rev. O.P. Cambridge in the 'Zuolugist' for 1559, p. 6444 .

Owing to this species being a native of the New World, and its having been only once secn in Lingland, I have not given a figure of it.

\section{Genus Dryocopus.}

As restricted, this genus contains but a single species. 
209. Dryocolud martids. Vol. III. Pl. IXXXIII.

Great Black Woodpecker.

This bird is of large size ; and the prevailing tint of its plumage is sooty black, relieved by red on the crown. Its native localities are the pine-woods of Norway, Sweden, and Switzerland. Nany instances of its haring been lilled in Britain are recorded; but it is probable that not one of them is authentic. At all events there is not a certified British-killed specimen in any of our Museums or private collections; consequently it is a very doubtful visitor. For further iniormation respecting it I refer my readers to the letterpress accompanyivg the Plate.

\section{Subfamily GECININAE.}

\section{Genus Gecinus.}

The member's of this genus (known as Green Woodpeckers) being less arboreal than the true Pici, spend much of their time on the ground. In Britain the trimly kept lawns and meadows are favourite places of resort. Their food mainly consists of ants and their larve. Besides $G$. viridis three more species iuhabit Europe; and other's are to be found in Asia and Africa.

210. Gecinds viridis • . . . . Vol. III. Pl. LXXIV.

Green Woodpecker, or Yaffle.

A resident species in England, in many parts of which it is known by the name of "Yaffle." It is rare in Scotland, and has not yet been seen in the sister kingdom of Ireland.

211. Gechnus viridis . . . . . Vol. III. Pl. LXXV. Green Woodpecker, or Yaffle (young).

\section{Subfamily COLAPTINAE.}

\section{Genus Colaptes.}

A purely American form, comprising about six or seven species, ranging from the United States to Bolivia.

\section{Colaptes auratus.}

Golden-winged Woodpecker.

A native of the eastern parts of North America, a single example of which was killed in Amesbury Park, Wiltshire, in the autumn of 1836 , as recorded by Mr. George S. Marsh, of Chippenham, in the 'Zoologist' for 1859, p. 6327, where he says, "My brother saw this bird in the flesh, just after it was shot. It was preserved by $\mathbf{M r}$. Edwards, of Amesbury, and has never been out of my possession." 


\section{Subfamily YUNGINA.}

\section{Genus Yonx.}

Only three or four species are known of this very anomalous Old-World form. Their range extends orer a great portion of the northern regions of Asia, entering Japan, and one species Eastern and Southern Africa.

213. Yunx torquilta . . . . . Vol. III. Pl. LXXVI. WRYNECK.

A true harbinger of spring, arrives before the Swallow, serenades us with its peculiar cry of Pee-pee-pae, and but seldom exposes its body to view. Is generally distributed over England and the southern portion of Scotland. Our Irish ornithologists must regret that it does not visit their country ; for a more curious creature does not exist. Many of its actions, and the character of its markings, have procured for it the trivial name of "Snakebird." 


\section{ORDER RASORES.}

\section{Family COLUMB E.}

The members of the Columbx, or Pigeons, may be said to be more universally dispersed than any other family of birds; for there is no portion of the globe, favoured with a temperate or warm climate, where representatives of one or more of the rarious genera of which it is composed do not exist. In round numbers, between three and four hundred species are now known; of these, four are inhabitants of Britain, one of which is a summer migrant.

\section{Genus Paldarbos.}

214. Palumbes toredatus . . . . . . Tol. IV. Pl. I. Wood-Pigeon or Cushat.

A stationary species, universally dispersed orer Britain and most parts of Europe and North Africa.

\section{Genus Coldmb.}

A form the members of which are chiefly confined to the old World.

215. Columba cenas . . . . . . . . Vol. IV. Pl. II. Stock Dove.

Partially migratory, but breeds with us.

216. Coldarba litia * * . . . . . Vol. IV. Pl. III.

Rock-Pigeon.

Common and stationary in all the rocky portions of Britain, the supposed origin of our domestic Pigeon.

\section{Genus Turtur.}

This genus is represented by the well-kuown Turtledove, that visits Britain in spring, to which several eastern species might be added.

217. Turtur adritus . . . . . . : Vol. IV. Pl. IV. Turthe Dove.

A true summer resident in all the southern and midland portious of Britain. 


\section{Genus Ectopistes.}

218. Ectopistes Mitgratorius.

Migratory Pigeon.

A native of North America: three or four instances of its occurrence in Englind and Scotland are on record. Not figured.

\section{Family TETRAONIDA.}

The Grouse (the trivial name for the members of this family) are among the most important of edible birds. They exist in very cir"umseribed limits, namely the northern portions of the Old and New Worlds. Those which frequent Britain are the magnificent Capercailzie, the Blackcock, the Red Grouse, and the Ptarmigan. Neither the Capercailzie nor the Blackeock is found in America; l ut that eountry is inhabited by species equally fine which are not found elsewhere.

\section{Genus Tetrao.}

219. Tetrao urogatlus . . . . . . Vol. IV. Pl. V. Capercatrzie or Cock of the wood.

Breeds in Scotland in abundance.

220. Terrao tetrix . . . . . . . Vol. IV. Pl. VI. BLAcícock.

A stationary and breeding species in the three kingdoms.

Genus Lagopds.

The well-known Red Grouse of England, Wales, Scotland, and Ireland may be regarded as the type of the present genus.

221. Lagopdes scotices. . . . . . . Vol. IV. Pl. VII. Red Grousf.

Inhabits England, Scotland, and Ireland, but not south of Wales. 222. Ligopus mutus . . . . . . . Vol. IV. Pl. VIII, Ptarmigan.

Stationary.

223. Lagopos hutos . . . . . . . Vol. IV. Pl. IX.

Ptarmigan (summer plumage). 
224. Lagopts yotus

Ptarmean (autumn plumage).

I hare considered it desirable to give three plates, illustrating three very distinet states of plumage, of this very variable bird.

\section{Genus Syrrihaptes.}

An Old-World genus of Sand-Cronse, comprising two species, the native haunts of which are the Steppes of Russia, China, and Thibet. A large number of individuals of the st. porutores made an extratordinary risit to rarions parts of the European continent and Britain in the years 1859 and 1860 .

225. Syrreaptes paradoxus . . . . . . . Vol. IV. Pl. XI. Pillis's Sard-Grodse.

For particulars see the text of the Plate referred to.

\section{Family PHASTANID AE.}

Genus Phasiands.

A genus of six or eight species, all of which are natires of tho northern regions of the Old World, from Asia Minor to Japan. Although Iudia, particularly its hilly portions, abounds in gallinaceous birds, no true Pheasant is found there.

226. Pmasiands colchicus . . . . . . Vol. IV. Pl. XII.

Common Pineasant.

A former introduction, probably from Turkey or some part of the neighbourhood of the Black Sea.

\section{Family PERDICID E.}

In this dirision of the Gallinacen is comprised a great number of varied forms, most of which are uatives of the northern portions of the Old World. In England we have two which may be considered indigenons, the Grey-and the Red-legged Partridge; the migratory Quail also frequently spends the summer in these kingdoms.

\section{Genus Perdix.}

A genus of three species, namely:- $P$. cinerea, habitat Europe; $P$. barbatus, habitat China; and $P$. Hodgsonice, habitat Thibet. 
227. Perdix cinereí

Vol. IV. Pl. XIII. Partridge.

A stationary species.

\section{Genus Caccabis.}

A genus instituted for the Red-legs, which differ conspicuously by their finer plumage and the presence of spurs on their tarsi.

228. Caccabis rubra . . . . . . . Vol. IV. Pl, XIV. Red-tegGed Partridge.

A stationary species.

229. Caccabis petrosa.

It is stated that wild specimens of this bird have been killed in England; but as this is questionable I do not figure it.

\section{Genus Coturnix.}

A form comprised of a limited number of species, which range generally over the Old World-Europe, India, China, the southernmost parts of Africa, Australia, and New Zealand.

230. Coturnix communis . . . . . . Vol. IV. PI. XV. Common Quame.

A summer but unecrtain migrant to England, while in Ireland it appears to be stationary; at least Quails are frequently seen there in winter.

\section{Family TURNICIDA.}

The Turnices (or Hemipordes, as they are frequently called) constitute a distinct group among the Gallinaceæ. About fifteen species are known, all of which inhabit the sandy portions of the Old World, but are most abundant in Australia. The European fauna comprises but one, indiriduals of which have now and then wandered to Britain, probably from Spain.

231. Turnit africhana . . . . . . Vol. IV. Pl, XVI. Andalusian Turnix.

An accidental visitor.

\section{Family OTIDID E.}

The Bustards, from their large size and noble bearing, constitute one of the most remarkable groups in ornithology. They are all in- 
habitants of the sandy plains of the Old World; and many of the most conspicuous species are natives of Africa.

\section{Genus Oris.}

Formerly Great Britain enumerated a fine bird of this genus; now and then, however, a solitary individual flies over to us from Spain or France, where it is still tolerably plentiful.

232. Otis tarda . . . . . . . Vol. IV. Pl. XVII. Great Bustard.

Accidental visitant.

233. Otis tetrax . . . . . . . Vol. IV. Pl. XVIII. Little Bustird.

Accidental visitant.

234. Otis Macruenit.

Macqueen's Bustard.

Quite accidental.

A native of Af whanistan and the neighbouring countries. A specimen of this bird, now in the possession of the Philosophical Society of York, was killed at Kirton Lindsey, in Lincolnshire, on the 7 th of October, 1847. Still, with so slight a claim to be cousidered British, I shall content myself with this notice of it and a reference to a figure which will be found in ny 'Birds of Asia.' Specimens have also been met with in Holland and Denmark.

\section{ORDER GRALLATORES.}

\section{Family GRUID E}

As must have been noticed by 'very one who has given a moment's thought to the subject, the Gruida, or Crames, differ from the Herons and every other group of birds of which this great order is composed. The larger number of the known species are inhabitants of the Old World, over which they are widely spread, the plains of Australia on the one hand and those of Hindustan on the other being frequented by one or more species; the form also occurs in $\Lambda$ frica, from north to south. In the New World, the northern portions only are tenanted by C'ranes; one species inhabits, or rather did inhabit, the British Islands.

235. Grus cinerea . . . . . . Vol. IV. Pl. XTX.

\section{Common Crane.}

An accidental visitant. 
236. Grus virgo.

Demoiselle Crane.

A natire of Southern Europe, Northern Africa, and India, has been scen and one shot in Orkney, in May 1863 (Saxby, 'Zoologist,' p. 8692). Not figured.

237. Grus patoninus.

\section{Balearic Crane.}

This bird has also been captured within the limits of Britain, and by some included in our lists of species-wrongly, howerer, as I think, since its true home is north-western $\Lambda$ frica, and its occurrence here must have been quite accidental.

\section{Family ARDEID 2 .}

If the Bitterns are inchuded among the members of this universally dispersed family, then the species amount to nearly a hundred in number. Unlike the Cranes, they are generally sedentary in their habits and affect watery situations. In the British arifauna there are ten species.

\section{Genus Ardea.}

238. Ardea cinerea . . . . . . . Vol. IV. Pl. XX. HERON.

Resident and very generally dispersed.

239. Ardea purpurea . . . . . . Vol. IV. Pl. XXI. Purple Heron.

This fine bird, which is abundant in Holland and France, can only be considered an accidental visitor to Britain.

Genus Herodias.

240. Herontas alba. . . . . . . . Vol. IV. Pl. XXII. Great White Egret, or White Heron.

Quite an accidental risitant, arriving at very uncertain periods.

241. Herodias garzetra . . • . . : Vol. IV. PI. XXIII. Litthe Egriet.

This, like the last, is merely a straggler to Britain.

Genus Bubulcos.

242. Bobulcus russatus . . . . . Vol. IV. Pl. XXIV. Buff-Bached Heron. An accidental visitor. 
Genus Bupmus.

243. Buphus comatus

Squacco Heron.

The visits of this bird are very infrequent, and its appearance not to be depended upon.

\section{Genus Nrcticorax.}

244. Nycticorax griseus . . . . . Vol. IV. Pl. XXVI. Night-Heron.

This bird must be considered among our accidental risitors.

Genus Botaurus.

245. Botaurus stellaris . . . . . Vol. IV. Pl. XXVII. Bittern.

Formerly a common stationary form in our marshes and fens; now seldom seen, and mostly in winter.

246. Botaurus lentiginosus . . . . Vol. IV. Pl. XXVIII. Anerican Bittern.

The frequent occurrence of this bird in the Iritish Islands demands a place for it in our arifauna; and hence I have given a figure of it.

Genus Ardetta.

247. Ardetta mindta . . . . . . Vol. IV. Pl. XXIX.

Little Bittern.

Although never to be found with certainty, it is probable that we are seldom without the presence of this interesting marsh-lover; it cannot, however, be considered other than a chance risitor.

\section{Family CICONIID $\mathrm{A}$.}

This family includes among its members not only our wellknown White and Black Storks, but at least twenty other species of those useful birds. Whatever the condition of Britain may formerly have been, it is no longer suited as a resting-place for either of the two species just mentioned; still scarcely a year passes without one or other of them accidentally dropping down on our marshes during their wanderings from one country to another. 
248. Ciconia ATBA

- Vol. IV. Pl. XXX. Writte Stork.

A chance visitor.

249. Ciconia nigra . . . . . . Vol. IV. Pl. XXXI. Brack Stork.

An accidental visitor.

Family PLATALEIDA.

The seven or eight known species of Spoonbills have been separated into a distinct family by Bonaparte. They are found both in the Old and the New World. Although so limited in species they are numerous in individuals, and are very widely dispersed over the surface of the globe.

250. Platalea leucorodia . . . . Vol. IV. PI. XXXII. Spoonbill.

An accidental visitor from the Continent.

\section{Family CHARADRIIDA:}

Mr. Harting, in his 'Handbook, has placed Edimemus, S'quaterola, Tuncthes, Eudromias, Éricalitis, Stiepsitas, and Hemetopus as a part of this great family of ground-birds; and I shall here follow his arrangement, since no one has paid greater attention to this subject than that gentleman. At the same time I must remark that perhaps no two persons will agree as to the position of $V$ ancllus.

\section{Genus Vaneluds.}

251. Vanellus cristatus . . . . Vol. IV. Pl. XXXIII. Lapwing, or Peewit.

Resident and generally spread over the three kingdoms. About four or five of this genus are known; they inhabit both the Old and the New World.

\section{Genus Himantopus.}

Of this form six or seren species are found in the old and the New World respectively. They are generally termed Stilts or StiltPlovers, and characterized by elegance in all their actions.

252. Himantopus candidus . . . . Vol. IV. Pl. XXXIV. Stilt, or Long-legged Plover.

An accidental visitor to Britain. 


\section{Genus EDicnemus.}

From four to six species of this form inhabit each side of the Equator in the Old World; two or three are similarly dispersed over America.

253. Gedicnemus crepitans . . . . . Vol. IV. Pl. XXXV. Thick-Kneed Bustari.

Common and stationary in Britain.

\section{Genus Squatarola.}

Our well-known Grey Plover is almost, if not the sole member of this genus.

254. Squatarola helvetica . . . . Vol. IV. Pl. XXXVI. Grey Plover.

A bird remarkable for the seasonal changes to which it is subject. In summer the breast is jet-black, while in winter the same part is striated or pure white. A bird of passage in Britain, proceeding northward in spring and returning southward at the opposite season.

255. Squatarola helvetica . . . . Vol, IV. Pl, XXXVII.

Grey Plover (winter plumage, and young).

\section{Gemus Charadrius.}

The well-known Golden Plover of England may be regarded as the type of this genus as now restricted. About five species are known, all characterized by the flavour of their flesh and the great seasonal changes to which they are subject in summer and winter, and which have induced me to give two plates illustrative of them. One or other of the five species inhabit most parts of the entire globe, but are more abundant in the Old than in the New World.

256. Charadrius pluvialis. . . . Vol. IV. Pl. XXXVili. Golden Plover (in summer plumage).

A resident species.

257. Charadritg plutialis . . . Vol. IV. Pl. XXXIX. Golden Plover (in winter plumage).

Genus Egralophilus.

A genus formed for the Kentish Plover and other allied species. 
258. Aegialophilus cantianus

Vol. IV. Pl. XI.

Kentisi Plover.

A spring and summer resident, coming here to breed in May. Common on the south coast.

\section{Genus AEgialitis.}

Of these little Plovers or Ringed Dotterels, as they are more commonly ralled, numerous species are spread over both the Old and the New World. Two are found in Britain-one of which is stationary, the other an accidental visitor.

259. Egialitis miaticula. • . . . Vol. IV. Pl. Xli. Ringed Plover.

A resident species, abundant in most parts of the three kingdoms. 260. Akgradits Minor . . . . . . Vol. IV. Pl. Xlit. Little Ringed Plover.

An oceasional visitant, the native country of which is Eastern Europe, Africa, and India.

261. Egralitis vocifera.

Kill-deer Plover.

This American bird has been added to the list of our fauna from the circumstance of a specimen having been killed in Hampshire in 1857.

\section{Genus Eudromias.}

The type and almost the only representative of this genus is the well-known Dotterel, which passes over the British Islands in May.

262. Eudromias morinellus - . . . Vol. IV. Pl. XliII. DOTTEREL.

Spring and autumn migrant; breeds in Westmoreland and the adjoining counties.

\section{Genus Corsorivs.}

A small genus of highly interesting birds which persistently keep to the regions of the Old World, and almost exclusirely to Africa and Asia. Swift of foot, they have been called coursers. They are said to trip orer the ground with great nimbleness, their movements then presentiug no inapt resemblance to pieces of paper blown about by the wind. They naturally inhabit great sandy wastes rather than cultivated and arable lands; and hence the only European species is but seldom seen. 
263. Cursorids galetcus

Vol. IV. Pl. XLIV.

Cream-colodred Courser.

Quite an accidental visitor to the British Islands.

\section{Genus Hematopus.}

Although not very numerous in species, there is scarcely any country on the face of the globe where this form is not represented. In the sonthern hemisphere, at Cape Horn in Ameriea, the Cape of Good Hope in Africa, in the southerumost portion of Tasmania and in New Zealand, a bird of this form is certain to be seen, while in the opposite hemisphere they are nearly as constant. These birds are commonly known by the misnomer of Oyster-catchers.

264. Hæmatopus ostrategus . . . . Tol. IV. Pl. XLV. Oyster-Catcher.

A resident species round our coasts.

\section{Genus Glareola.}

An isolated form among the Plovers. The six or seven speeies known are all confined to the Old World. Their chief food consists of insects, which they capture on the wing, after the manner of the Swallow.

In speaking of an allied species (G. melanoptera), Mr J. II. Gurney, in Andersson's 'Birds of Damara Land,' states :-_." The principal enemy of these great swarms (of locusts), and the valued friend of the Cape farmer, is the small locust-bird, Glarcola Norelmanni .... . These birds come, I may say, in millions, attendunt on the flying swarms of locusts: indeed the appearance of a few of them is looked upon as a sure presage of the locust swarms being at hand. Their mode of operation, as I saw it, was as follows:--They intercept a portion of the swarm and form themselres into a ring of considerable height, regularly widening towards the top, so as to present the appearance of a revolving balloon or huge spiming-top. 'They thus fly one over the other, and, hawking at the locusts, gradually contract their circle and speedily demolish the locusts within its limits. As their digestion, like that of all insectivorous birds, is very rapid, the form in which they thus enclose their prey is admirably adapted to enable the lower to escape the droppings of the upper birds. When they have consumed this portion of the swarm, they follow up the main body and commence another attack, and so on, until night sets in and the birds happen to lose the swarm or the locusts are all deroured. I should not forget to mention that the beak of these birds is exactly of such a shape and such dimensions that when they seize the locusts the snap cuts off the four wings, and a passer by sees a continual shower of locusts' wings falling on the ground. At another time, when I was stationed at Fort Peddie, and the country was suffering from the effects of a 
long drought, and was overrun with unusual quantities of ants and grasshoppers, we were risited by thousands of these birds, which remained many days devouring these pests. Though the locustbirds are excellent eating, no one ever thinks of destroying them; and they are so fearless that, though I often rode or ran amongst them to test their tameness, only a few in my immediate vicinity would rise, the rest continuing to feed; but every ten minutes or so the whole mass would rise of their own accord and fly, first a few yards to the right and then to the left, in a slanting direction, presenting alternately a black and white wave of birds some miles in length, a sight never to be forgotten by the spectator.

265. Glareola pratincola.

Common Pratincole . . . . . . Vol. IV. Pl. XLVI.

An accidental visitor to the British isles.

\section{Family TANTALID瓜.}

Genus Falcinelius.

266. Falcinellus igneds

GLossy Iвis.

This bird has a wide range, being found in Europe, India, Africa, and Australia. Accidental in Britain.

\section{Family SCOLOPACID压。}

Under this family name I shall, like Mr. Harting, include many forms of strand- and marsh-loring birds, beginning with the Curlews and ending with the Snipes.

\section{Genus Numenivs.}

The birds of this form will be found described in all general histories of birds under the trivial name of Curlews and Whimbrels. One or other of the species are distributed over every country of the entire globe. In Britain we have two vers distinct kinds, to which a third, a straggler from America, has just been added; here, however, it will only receive a passing notice.

267. Numfaides arquata . . . . . Vol. IV. Pl. XLVIII. Curlew.

Resident and universally dispersed. Lives much on the sea-shore during winter, and in summer resorts to heathery hills and wastes for the purpose of breeding. 
268. NUMENIUS PHEOPU⿴ Vol. IV. Pl. XLIX.

WHIMBREL.

A spring and autumn visitant, learing us at the former period for regions further north, whither it proceeds to breed.

269. Numenius boreatis.

Esquimaux Curlew.

This bird has been shot in this country about four times; being, however, purely an American species, it is not figured.

\section{Genus Lrmosa.}

Godwits, like Curlews, are all but universally dispersed over the sea-shores and marshes of every country.

270. Limosa melandra . . . . . . . Vol. IV. Pl. L.

BLack-tatled Godwit.

Formerly used to breed in our marshes, but now, owing to the progress of cultivation, can only be regarded as a migrant.

271. Limosa refa . . . . . . . . Tol. IV. Pl. LI. Bar-talled Godwit.

A regular spring and autumn migrant, going northward to breed, and returning southward in winter.

\section{Genus Recurvirostra.}

Of this highly interesting genus there are three well-marked species known :- the present, which is common in Europe and Africa; the second, which is found in North America; and the third, a beautiful red-necked bird, is a native of Australia.

272. Recurvtrostra avocetta . . . . Vol. IV. Pl. LII. A

\section{Genus GLotris.}

273. Glottis canescens . . . . . . Vol. IV. Pl. LIII. Greenshank.

A spring and autumn migrant, breeding in Scotland, where of late years many nests have been discovered.

Genus Totanes.

274. Totanus calidris . . . . . . Vol. IV. Pl. LIV. Redshank.

Formerly a common resident species in our fens, and breeding 
regularly in many parts of England. Drainage and cultivation of waste lands, howerer, have almost driven it from our shores, except at the periods of its migration in spring and autumn.

275. Totanus fuscus - . . . . . . Vol. IV. Pl. LV.

Spotten Redshank.

In England and Scotland this bird is generally regarded as a spring and autumn migrant; and no instance of its nesting with us has yet been recorded, notwithstanding that individuals of this species frequently remain here long enough in the spring to acquire their full summer plumage. In Ireland it is said to be very rare.

276. Totanus ochropus . . . . . . Vol. IV. Pl. LVI.

\section{Green Sandpiper.}

Although strictly speaking this Sandpiper is only a spring and autumn migrant, examples are now and then obtained in winter, and it has even been reported to have nested in this country. This is by no means unlikely; but its remarkable habit of depositing its eggs in the old nests of other birds at a considerable height from the ground, has no doubt caused it to be overlooked.

277. Totands glareola . . . . . Vol. IV. Pl. LVII.

WOOD-SANDPIPER.

Like the last-named this species is most frequently observed at the vernal and antumnal periods of migration; but two or three instances of its nesting in Norfolk, Northumberland, and Elginshire have been placed on record.

Genus Actrtrs.

278. ACTITIS HYPoLEUCos Vol. IV. PI. LVIII.

\section{Summer-Snipe.}

This well-known and graceful little Sandpiper, like others of the family, is a bird of double passage, and appears with great regularity every spring and autumn. Unlike other species, however, it does not always quit this country to find a nesting-place, but breeds regularly in the north of England, Wales, and Scotland, and less frequently in some parts of the south of England.

279. Ictitis macularta . . . . . . Vol. IV. Pl. LLX.

Spotted Sandpiper.

An inhabitant of the northern continent of America, this bird can ouly be regarded as a rare straggler to Europe and the British Islands, where it is reported to have been met with sereral times. 
Genus Strepsilas.

280. Strepsitas INTERPRES . Vol. IV. Pl. LX:

Turnstone.

Although a regular migrant to our shores, a few remain with us throughout the winter, and there is good ground for believing some breed within the British Islands. See Harting, 'Handloook of British Birds,' p. Ht; Gray, 'Birds of West of Scotland;' and Thompson, 'Birds of Ireland,' vol. ii. p. 120.

\section{Genus MACHetes.}

281. Macmetes pdgnax • . . . . . Vol. IV. Pl. LXI.

RufF and REeve

This bird formerly nested regularly in the fens; but, owing to the gradual drainage of their haunts, and undue persecution in the spring, very few now breed here, and that only in faroured localities. It is still, howerer, a regular spring and autumn migrant.

282. Mlachetes pugnax . . . . . . . Vol. IV. Pl. LXII.

RUFF and ReEve (first autumn plumage).

s

Genus Actituros.

283. Actiturdos Bartrantus . . . . . Vol. IV. Pl. LXIII. Bartray's Sandpiper.

A rare straggler from the New World, which has been met with in England in three or four instances at rare intervals.

\section{Genus Tryngrtes.}

284. Tringites RUfescens . . . . . Vol. IV. Pl. LXIV.

BUFF-BREASTED SANDPIPER.

This is another wanderer from the American continent. It has been noticed, however, more frequently in this country than the lastnamed: Mr. Harting, in his ' Handbook of British Birds,' p. 138, has given fifteen instances of its capture here.

Genus Trivad.

285. Tringa canutus . . . . . . Vol. IV. Pl. LixV. KNот.

Although a few of these birds may be found here throughout the winter, it is strictly speaking a spring and autumn migrant. 


\section{Genus CaIidpris.}

286. Calidoris arenaria SANDERLING.

The same remark applies to this as to the last-named.

\section{Genus Limocinclus.}

\section{Linnoctnclus pectoralis . . . . Vol. IV. Pl. LXVII. Pectoral Sandpiper.}

Like Bartram's Sandpiper and the Buff-breasted Sandpiper, this bird, which is common to both continents of America, occasionally finds its way across the broad Atlantic, and a temporary home in this country. According to Mr. Harting ('Handbook,' p. 140), some sixteen instances of its occurrence are on record.

\section{Genus Avcrlocheilds.}

288. Ancylocheilus subarquata . . . Vol. IV. Pl. LXVIII. CURLew Sandpiper.

Like many others of the Sandpipers, this bird is a regular spring and autumn migrant. The discovery of a nest in a tract of sedgy bog round the Loch of Spynie, near Elgin, on the 8th of June, 1853, has been recorded by Mr. R. Gray in his 'Birds of the West of Scotland.'

\section{Genus Peliona.}

\section{Pelidna cinclus}

Dunliv (summer plumage).

Although a resident species, the Dunlin is nevertheless migratory in spring and autumn. It breeds regularly in Scotland, the Hebrides, and Shetland; and the nest has also been found on the moors of Northumberland and Cornwall.

290. Pelidna crnclus . . . . . . Vol. IV. Pl. LXX.

DUxurn (winter plumage).

291. Pelidna Bonapartei • . • . Vol, IV. Pl. LXXI.

Bonaparte's SANDPIPER.

This American species, of which some eight or nine examples have now been procured in this country, is probably more familiar to English readers by the name of Schinz's Sandpiper. It is now generally admitted, however, that the so-called Tringa or Pelidna Schinzii is merely a small variety or race of the Dunlin; and the appellation should therefore cease to be employed for the present species. 
Genus Actonromas.

292. Actodromis MiNUti

Tol. IV. PI. LXXII.

LitTtLe Stinte.

This graceful little bird is a regular migrant, passing through this country in spring and autumn. It is always more numerous at the latter season, which seems to indicate that the species on groing northward in the spring travels by another route than that which it traverses on its return in autumn.

293. Actonromis pusthei.

American Little Stint.

An American Little Stint (A. pusilla, Wilson) has twice been met with in England. In October 1553 a specimen was shot on Marazion Marsh, Cornwall; and in September Lisig a second was obtained on Northam Burrows, Devon.

'This purely American bird has not been figured.

\section{Genus Lemionites.}

294. Lemroxites 'Temminckit . . . Vol. IV. Pl. LXXIII. 'T'emnitack's Stint.

This little Sandpiper, although of ratrer oreurrence than the last named, visits this country nevertheless regularly in spring and autumn. It appear's, howerer, to be almost confined to England; for it has been met with only once in Scotland, and once in Ireland.

\section{Genus Arouatert.}

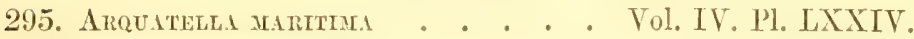
PURple Sinpiper.

Throughout the greater part of the British Islands this bird is chiefly known as a wiuter visitant; and although it has becn observed late in spring in the Itehriles, and yresmalsly breding there, no one has yet been fortumate enough to discover a nest there.

\section{Genus Linicola.}

296. Linicold prguled . . . . . Vol. IV. Pl. IAXXV.

\section{BRo.ID-TILLED SINDPIPER.}

An inhrlitant of Northern Europe ant Lsia : this lit tle bird mores sonthward at the approach of winter, and in four or five instaness has strayed far enough towards the west to touch the English shore.

In every instance in which specimens have been obtained here, save one, the locality was the coast of Norfolk. 'The exceptional capture was made in Belfast Bay many years ago. 
Genus Macrominypmos.

297. Nacromianipius griseus. . . . Vol. IV. Pl. LXXVI.

Ren-mreasted or Brown Sinipe.

In Mr. Ilarting's ' Handbook of British Birds' (p. 141) no less than fifteen instances are given of the occurrence of this NorthAmerican species in England and Scotland. In every case, so far as can be ascertained, the specimens were procured in autumn, indicating that their presence here is in some way dependent upon a divergenee from the route of their migration southward.

Under the terms Scolopare, Gallinayo. and Limnocryptes those members of the true snipes which do not visit Britain have been figured. They form part of a group of universal distribution.

\section{Genus Scotopla.}

298. Scotop.ti rusticola . . . . Vol. IV. Pl. LXXVII.

WoODCOCK.

This well-known species of late years has become so much more mmerous here as a resident, that although numbers still migrate to this country in the autumn, it is difficult to say whether "the first cock of the scason" is an curly arrival or a home-bred bird.

\section{Genus Gilimigo.}

299. Galitinago major . . . . Tol, IV. Pl. LXXVIII.

Greit SNIPE.

Although this species does not, like the next, breed in this country, it visits us regularly every autumn, bat always earlier than does the Common Sinipe; and its occurrence during the spring months is rare.

300. Galimigo scoloplotina . . . . Vol. IV. Pl. LXXIX.

\section{COMMON SATPE.}

A regular winter visitant; hut in fitvomable localities many annually remain to nest and rear their young.

With regard to the so-ealled Sabine's Snipe, it is now generally regarded as a melanism of the common species, but is of sufficiently rare occurrence to atract notice. In the 'Field' of Dec. 10, 1870, appeared a list to that date of all the known examples which had been obtained, since which time two or three others have been killed in the south of England, and, for the first time, one recently in Foolland. Mr. Jirydges Williams's specimen was shot at Cannanton, Cornwall, in January 1862. As to this, sce 'Zoologist,' 1862, pp. 7883 and 7938. 
301. Gilitinag ressata.

Russet Snipe.

This remarkable Snipe, which often weighs six ounces, not unfrequently oreme in our markets. Mr. Rodd, of Penzance, and sportsmen generally, often speak of this bird when mriting to a friend, asking its name \&e. The term russate will be foum mentioned in the folio edition in the letterpress to the Common Snipe.

Genus Limacriptes.

302. Limiocriptes gatidixul . . . . Tol, IV. Pl. LXXX. JACK SXIPE.

Although instances are on record in which this bird has been met with in this comntry in summer, there is no sufficient evidence of its having bred here, and it must continue to be regarded as a regular winter risitant.

The generic terms Phalaropus and Lobipes have been instituted for the fitiry-like Phalaropes, of which there are three suecies, two of which frequent Britain.

\section{Genus Pinalaropus.}

303. Pinaliropes fulicarius . . . . Yol. IV. Pl. LXXXT.

Grex Pilalarope (summer plumage).

This beautiful little bird has of late years been noticed as a regular autumn risitant, occasionally aplpearing in considerable numbers. It is remarkable that although flocks lass through England in the autumn (when the suecies is moring southward for the winter), none are secn here on the return journey in spring, which shows that they go back by a different route.

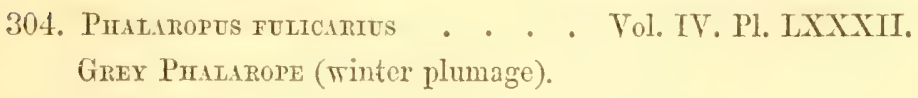

Genus Lomipes.

305. Lobmens mipenboreus . . . . Vol, IV. Pl. LXXXIII. Red-necked Phalaropu.

In England this graceful little bird is an oceasional wintor visitant. Nerer seen in such numbers as the last named, but generally singly or in pairs. It has been found brecding in Orkney, the Hebrides, Perthshire, Inverness, and Sutherland; but in Ireland it appears to be unknown. 
Genus Fulta.

Coots are so generally dispersed over the globe as to render it diffienlt to say where one or other of the fifteen speeies are not to be met with.

306. Fulica atrl . . . . . . Vol. IV. Pl. I.XXX1V. Coot.

This well-known species, although generally regarded as a resident, is nevertheless migratory to a certain extent in autumn, and assembles often in large flocks in the winter, in our estuaries and tidal harbours.

\section{Genirs Githinult.}

Like the Coot, the members of the genus Gullinule are very generally dispersed over both the Old and the New World.

307. Gallindli chloropus . . . . Vol. IV. Pl. LXXXV. Moormen.

Of this familiar bird it will suffice to say that it is resident and generally distributed.

Genus Ritisus.

Rails are, like the Coots and the Moorhens, inhabitants of marshes of the entire globe.

308. Rillues aquaticus . . . . Vol. IV. Pl. LXXXVi. WATER-RaIL.

There can be no doubt that, althongh many birds of this species remain with us throughout the year, considerable additions to their numbers are made in the spring.

\section{Genus Crex.}

Allied in form and rery similar in distribution to the three foregoing and the next following genera.

309. Crex pritexsis. . . . . . Vol. IV. Pl. LXXXVII. LAND-RAil or ConN-Crine.

A regular summer migrant : but oceasionally individuals have been found loitering behind and spending the winter with us in sheltered situations.

\section{Gemus Porzaxa.}

310. Porzana maruetri. . . . . Vol. IV. Pl. LXXXXIIT. Spotted Crane.

Whatever mny have been the case formerly, when our fens were 
the regular nesting-hames of this and many other marsh-loving birds, the spotted C'ratie can now only he comsidered a spring and autumn migrant, oceasionally remaining to breed in farourable situations.

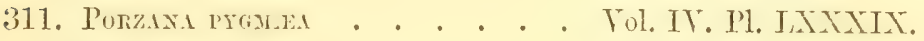

BIILLON'S CHATT:

This little bird has so frequently been met with in England and at almost every season of the year, that an cnumeration of particular localities for it is mnecessary. It may be regarded as a local resident. It has, however, been only obtained once in Scotland and once in Ireland.

312. Porzaxi mistet . . . . . . Tol. IV. Pl. XC.

Oliticeods Crike.

Almost the same remark will apply to this as to the last-named species, although the seasons at which it has been generally met with seem to indicate that it is a spring and autumn migrant.

\section{ORDER INATATORES.}

In this order Vigors and others have included all the swimming birds-Geese, Swans, the two grat civi-ions of the Ducks, Hergansers, Cormorants, Auks, Grebes, Penguins, Jivers, Gulls, Terns, and Petrels. Their distribution is alnost mirersal, the icy boles being the only part of the globe from which they are absent.

If we institute a comparison betseen the ornithological productions of the different lurts of the earth s surface, we find that waterbirds are much more rife in some countries than others, and that they are more numerous in the northern than in the southern hemisphere; and if we compare those frequenting the area of the Hiritish Islands and the surrounding seas and fresh waters with tho-e frequenting a similar extent of any other portion of the globe, we shall find a greater rariety of forms than elsewhere, due doubtless to the peculiar position of our islands, lying as they do betwern the two great northern continents, and to a certain extent under the influence of the Gulf-stream.

I now proceed to the enumeration of the species contained in the fifth rolume, and commence with the Gecse, two or three of which grace our wolds and marshes.

\section{Subfamily ANSERIN E.}

In round mumbers about thirty species of Gecse are now known 
to ornithologists. Ther arlmit of being divided into many genera,

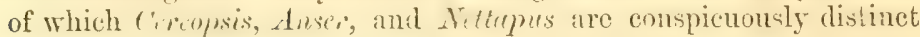
from each nther; it is, howerer, with the gewera Anser and Bernicle only, or true Geese, that we have to do with in the 'Bircls of Great Britain.'

\section{Genus Axser.}

313. Axger furtes . . . . . . . . Vol. V. Pl. I.

\section{Gray Lile Goose.}

A stationary species. Brecds in many parts of Scotland and Ireland. 'The original of our Common Goose.

314. Axser shgetuli . . . . . . . . Vol. V. Pl. II. BEAN-Goost.

A winter visitant. Mrore common on the western than the eastern parts of Scotland and England.

315. Anser nrichypHrNCHUS . . . . . Vol. V. Pl. III. PrNK-Footed Goose.

A winter visitant, arriving from the north in autumn; plentiful in the wolds of Yorkshire at that season.

316. Anser albifrons . . . . . . Vol. V. Pl. IV. White-Fronted Goose.

This is also a winter visitant to the British Islands.

317. Axser Iigrticus.

Egyptian Goose.

Supposed by some to be an occasional visitor, by others that those which are occasionally seen are stray individuals from some domestic home.

318. Anser albatus.

Cassin's Snow-Goose.

Sce Howard Faunders, in the "Procectings of the Zoological Society of London,' Minch 1872, for an account of two specimens of this bird killed in Wexford Harbour in November 1871.

Genus Bernichd.

319. Bermicla leucopsts . . . . . . Tol. Y. Pl. Y.

Bernicle Goose.

Plentiful in winter, kerping to certain districts on the flat shores of Lancashire. Retires northward beyond our country to breed.

320. Beryicta canadensis.

Canada Goose.

This hird is said to have ocentred wild in England; it being purely Amerjean, I hare not figured it. 
321. Bepartelil runtcotits Tol. V. Pl. VI. Red-brelsten Goose.

An inhabitant of northern Russia and Siberia, and a chance visitant to Britain.

32.2. Bernetcli brexte. . . . . . . Vol. V. pl. Vil. Breitt Goose.

Plentiful in winter on the muddy flats at the mouths of rivers from the Thames to the 'Tamar; cequally numerous in a northerly direction, including Ireland.

\section{Subfamily CYGNINA.}

Of this subfamily there are nine or ten species-three or four of which pertain to the fum of (ireat Britain, two or three to that of North Ameriea, the eclebrated Black-necked Swan of (thili, and the Black Swan of Australia.

323. Crands olor . . . . . . . Vol, V. Pl. VIII. Mote Swar.

Supposed to be still living in a wild state in Eastern Europe; strictly stationary in Britain.

324. Crganes ferits . . . . . . . . Tol, T. Pl. IX.

\section{Wild Sifan, or Wrooper.}

A winter visitant, arriving in antumm and departing in spring, to breed in Ireland and many parts of the arctic circle.

325. Cycines miror . . . . . . . . Tol. T. Pl. x. Bewick's Swan.

This is also a winter visitor, arriving in antumn and retiring northwards in spring.

326. Crgnus mamutabitis.

Polish Swan.

Ornithologists are at variance as to the propricty of considering this bird a distinct species from $C$. olor, the difference between them being but trifling. The Polish Swan is a somewhat larger bird, with a smaller frontal knob, while the naked space between the bill and the eye is larger; and the feet are grey instead of olivehack. Mr. Bartlett has weighed several Polish trans living at the Zoolonical Gardens, which turned the scale of twenty-suren pounds; and he assures me they would he tro poubd hearier after monlting. He considers there are tangible differences between the two birds; and I must confess I do also since I have been able to make some 
obscriations on a fine example recently shot, as detailed in the following note sent to me by Viscount Holmesdale :-

\author{
Househill, Nairn, N.B., \\ Sept. 28 th, 1872.
}

Dear Mr. Gould, - I send you a bird which I believe to be a Polish Swan. liirst a pair and then three others came to a wild loch by the sea here in the northerly gales we have had lately. The kceper took them to be common Whoopers; and we went out yesterday and stalked them. Whoopers they certainly are not; but they answer cractly to the description of the Polish Swan in Yarrell : ash-grey ligs and fect small; tubercle at base of bill and the black of the nostrils well divided from the base. If this is so, it may be of interest to you; and Colonel Baillie hopes you will accept the bird. If, after all, we are wrong as to the species, it may be of interest from the culinary point of view.

\title{
Yours very faithfully, \\ HoLamesdLe.
}

The very fine specimen abore alluded to is now mounted in the Tritish Muscum; and I have a note on its dissection from Professor Owen, who states "the Swan was a young male, testes very small, flesh tender and good eating."

If the young of this bird is always white from its downy state upwards, it is a remarkable characteristic, and one that will tond to confirm the propriety of considering it a species.

The weight of this individual was $24 \frac{1}{4}$ los.

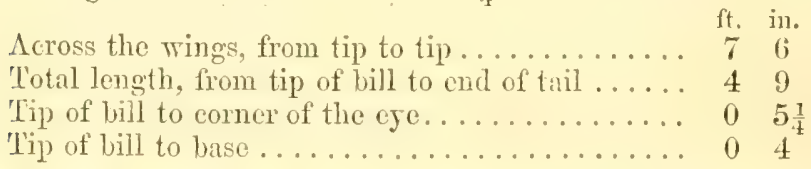

Bill deep reddish flech-coloux, with a tolerably well-dereloped knob and broad triangular space between the hill and the ere. Breadth of the black space, including the part bebind the linob, :inches. Eye dark brown.

Feet olive-grey, even to the joints; interdigital membrancs darker. Length of true tarsi $4 \frac{3}{4}$ inches; bare space above the joint $1_{2}^{1}$ inch; middle toe and nail $6{ }_{4}^{1}$ inches: breadth of the foot $6 \frac{1}{4}$ inches.

Having disposed of the Gecse and Sirans, we naturally turn to the true grass-feeding Ducks, after which will be noticed those species which almost exchusively feed under the surface of the waterthe Fuliguline \&c.

Subfamily ANATINA.

Genus Tadorna.

An Old-World group of five or six species. 


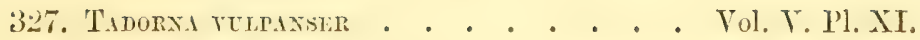
SHFidrake.

A stationary species, breeding in the holes of warrens and sandy wastes by the sea-side.

Genus Casarea.

328. Cis.rach rutili . . . . . . . Vol. V. Pl. XII. RUDDY SHHLDRAK.

An occasional and very rare visitant. Among other places, builds in rocks on the borders of the Mediterranean.

\section{Genus Mareca.}

A genus of which our common Widgeon is the type, and of which an allied species is found in North America and another in Chili.

329. Mlarech penelote • • . . . . Vol. V. Pl. XIII. WIDGEON.

A migrant which is plentiful in winter, and sometimes, but not rery regularly, stays to breed in England and Scotland.

330. Mareca americais.

American Widgeon.

An occasional risitant to England. It is not figured.

\section{Genus Spituta.}

A well-defincd form, comprising about six species, one bcing found in Australia, another in New Zealand, others in Chili, and the rest in the northern hemisphere of both the Old and New Worlds.

331. Spatula clypeata * . . . . Vol. V. Pl. Xiv. Shoveller Deck.

Frequent in summer, sometimes breeds.

\section{Genus Aras.}

The Wild Duck, which is the type of this genus, is generally diffused orer Asia, Afriea, and North America.

332. Axas roscmis . . . . . . . Vol. V. Pl. XV. Mrathatad, or Wilid Dech.

Resident, and breeds everythere. The supposed parent of all our domestic breeds of Ducks.

\section{Genus Querquedula.}

A genus formed for the Teal and Garganey and some allied species in other parts of the world. 
333. Quereuederi crecci . . . . . . Tol. V. Pl. XVI. 'TE.II.

Common, resident, breeds everywhere.

334. QuerQdedula circta . . . . . Vol. V. Pl. XVII. Garganey.

$\Lambda$ spring and antumn migrant, occasionally remaining in the summer to breed.

\section{Genus Difili.}

Formed for the reception of our well-known Pin-tailed and two or three South-American species of elegantly formed Ducks.

335. Dafita acuta

Pin-taILed Duck.

$\Lambda$ winter visitant, arriving in sufficient numbers to be regarded as common.

\section{Genus Chadufuasius.}

The bird characterized under this term is almost the sole type of the genus.

336. Chadlelasmus strepera . . . . Vol. V. Pl. XIX. Gadwate.

A somewhat rare winter visitant.

\section{Genus Nrrocs.}

In Britain there are two species of this genus; in North America there are others, and others again in Australia.

337. NYroCA FERINA

\section{Pocmard.}

A winter visitant, frequently taken in our decoss, and the flesh held in some esteem as representing the colebrated Canvas-backed Duck of America.

338. Nrroca ledcophthadios . .. . . . . Vol. V. Pl. XXt. Wiite-eted or Ferreginous Duck.

A spring visitor, almost exclusively so in England, but unknown in Treland.

\section{Genus Branta.}

A fine form, the mative country of which is Eastern Europe and India. 
339. BRANTA RUFINA Vol. V. 11. XXII. Red-crested Deck.

The occurrence of this bird in England is rery seldom and nnecrtain; still there are many British specimens extant.

\section{Subfamily FULIGULIN ג.}

The birds of this subfamily, or the Diving Ducks, form an extensive group, members of which are found in most parts of the globe, and which is well represented in the British Islands.

\section{Genus Furgull.}

340. Fuligdli cristimi . . . . . Vol. V. Pl. Xxitr. Tueted Duck.

A tolerably common winter visitant to the British Islands ; many remain to breed on the lakes at Clumber and Osberton in Nottinghamshire, and doubtless on other similar sheets of water.

341. Fultguta mariti Vol. V. PI. XXIV. Scaup Duck.

A winter visitant.

Genus Entconetra.

I genus established for the fine Steller's Duek, a species nearly allied to the Eiders.

342. Exiconetti Steliert . . . . . Vol. V. Pl. XXV. Stelier's Duck.

An accidental risitor to the northern parts of Britain ; its native countries are Lapland, northern Scandinavia, and Russia.

\section{Genus Somateria.}

Of the Eiders, a very natural and distinct group of Ducks, there are but four or fire species, inhabiting the northem portions of both the Old and the New World.

343. Somateria mollissima . . . . Vol. V. Pl. XXVi. Etmer Duck.

Stationary. Breeds on the Farn Islands and many other similar situations round our northern coasts.

344. Sonlateria spectabilis . . . . Vol. V. Pl. XXVII. KING Deck.

$\Lambda$ rare and accidental visitor from the north. 


\section{Gemus Ornmis.}

The members of this little division of the Diring Ducks are rendered remarkable by their velvety black covering, as well as the bright colouring of some of the soft parts, particularly of the bill and the naked portions of the head of one species. They are strictly denizens of the salt waters, resorting to freshwater lakes only for the purpose of breeding.

345. Oinemia nigra . . . . . Tol. V. Pl. XXTIII. Scoter.

Very common along our coasts in winter; a fair number stay to breed in Caithness and Sutherland.

346. Oidemia fusca . . . . . . Vol. V. Pl. XXIX.

Velvet Scoter.

A common winter bird in the Orkney and Shetland Islands; solitary indiriduals have been killed on the thames and eren further south.

347. Oidemia persptcillati . . . . . Vol. V. Pl. XXX. Surf-Scoter.

Quite an accidental visitor from the coasts of North America; has been killed about ten times in Britain.

\section{Genus Clixguta.}

The Golden-ese, Barrow's Duck, and the Dinfle-lended Duck are about the only members of this genus; like sercral of the preceding forms they scek their food at the bottom of the shallow parts of the seas, the inlets of rivers, \&c.

348. Clangula gladcion

Vol. V. P.]. XXXI.

GoLDEN-Eye.

A true winter visitant, said to have once found a brceding-place on Loch Assynt in Sutherland. Breeds in Lapland.

\section{Clanguta albeola.}

349. Buffle-headed Dnck.

This American bird haring been killed four or five times in Fingland, some have included it in our avifauna; and so do I, but without figuring it.

\section{Genus Histriontcus.}

The fantastically marked IIarlequin Duck is the type and only known species of this genus. 
350. Histrionters torquites Vol. V. Pl. XXXII. Hirlequin Duck.

A rery rare visit mt to Britain : and when examples do occur, they are either females or young males of the first year.

\section{Genus Hireid.}

$\Lambda$ northern form of a single species.

351. Haretdi Gracrieis

Vol. V. Pl. XXXIII. Loxg-timLed Duck.

A common winter risitant; arrives in the Scottish firths in great abundance during the months of autumn.

\section{Subfamily MERGIN E.}

The Mferganser's are a very distinct fumily, differing in structure and mode of life from the Ducks or Cormorants, to which otherwise they are nearly allied. They live on the waters of both the Old and the New World, and consist of about ten species.

352. Merges castor . . . . . . . Vol. V. Pl. XXXIV.

Goosander.

A winter bird, frequenting our lakes when they are not frozen over; very destructive to freshwater fish. Always to be seen at Clumber in autumn and winter, goes north in summer.

353. Merges serritor . . . . . . Vol. V. Pl. XXXY. Merganstir.

Found in Britain at all seasons; common in the north of Scotlind.

35t. Mergus cuculditus . . . . Vol. V. P1. XXXVi. Hooded Merg.lNser.

An American species, which has oceasionally been found in Europe and Britain.

355. Mergus albellus . . . . . Vol. V. Pl. XXXVII. Sxrew, or Nux.

A winter bird, rather scarce. Breeds in Lapland and the adjoining countries.

Family PODICIPIDA.

When the birds of the world are taken in review, it is interesting to note that certain forms are restricted to very limited 
areas, while others are as widely distributed. It is to the latter category that the Grebes or members of this family pertain ; for my experience tends to prove that one or other of the mumerous species are found thronghout the entire globe; even in the islands of the Sionth Pacific they are to be met with, and also all orer North and Fouth Ancrica. 'They do not appear to be limited by cleration, but tenant the lowest waters and the highest lakes, one of the finest being an inhabitant of the celebrated Lake of 'Titicaca in I'ern. Gircbes are characterized by a peculiarity of structure which enables them to chase the nimble fishes and other aruatic creatures under water in a different manner from other birds. They construct their floating uests on the lakes; and the eggs are frequently incubated in the water. Althowgh divided into many genera, those inhabiting Britain have been retained in the genus Podierps.

356. Podicers cristatus . . . . Vol. Y. Pl. XiXVIII. Great Crested Grere.

A summer resident, breeding on many of our large likles and inland waters.

357. Podiceps rubrjcollis . . . . . Tol. V. Pl. XXXTX. Red-Necked Grebe.

An occasional risitor, not rare on the east coast in the winter seasoll.

358. Ponicres auritus . . . . . . Vol. V. Pl. Xl. Horned Grebe.

A chance visitor to Britain, most common in its immature and winter plumage ; inhabits Sireden, Lapland, and other comtries to the northward of our islands.

359. Podiceps nigricollis . . . . . Vol. V. Pl. Xlt. Eared Grebe.

More numerous than the last; sometimes found on the eastern broads in its finest state of plumage. One of its native countries is Spain; it is also abundant in Northern Afriea, and but seldom, I imagine, found so far north as the Baltic. Probably unknown to Limnacus.

360. Pontcers misor . . . . . . . Tol. V. Pl. XLII.

LtTthe Grebe, or DABCHick.

A resident, stationary, and universally distributed species.

\section{Family COLYMBID ג.}

The Divers, mulike the Grebes, are only fomd in the northern 
hemisphere. They frequent the countries bordering on the aretic circle, and are as abment in America as in Europe and Asia. In Britain we have three distinct species.

361. Colmures aldcialis . . . . . Vol. V. PI. Xltit. Great Northern Diver.

One of the finest of our native birds, but does not breed with us.

362. Colymbes arcticus • . . . . Vol. V. Pl, XliV. Bhack-throated Diver.

This may be considered a resident species, although it is but sparingly observed at any time. In winter the young are frequent along our southern coasts, while in summer most of the northern lochs of Scotland have each its breeding pair of birds - among other places, Loch-y-vraon and Loch Drome in Ross-shire, part of the fine property of John Fowler, Esq.

363. Colymbers septentrionalis • . . . Tol, V. Pl. XlV. Red-throated Diver.

Like the last a resident speries, breeding in the same parts of the country.

\section{Family ALCAD A.}

Formerly Britain could boast of having five species of this remarkable family of northern sea-birds; but the finest of them, the Great Auk, is now gone from the face of the waters; and if it is still enumerated in the present work, it is because we cherish the recollection of so singular a bird.

Genus Alca.

364. Alch mupenvis . . . . . . . Vol. V. Pl. XlYI. Great AUr.

365. Alca torda

RAzoritLt.

A common cliff hird, breeding all round our coasts, and a constant resident on our seas.

Genus Uria.

366. Unta trolte . . . . . . . Vol. V. Pl. XLVIII.

Comanon GUILLejot.

Like the last very numerously dispersed round the whole of the islands and islets of Britain; breeds on the rocks ; lays but a single egg. 
367. URLA GRYLLE

\section{Blich Guiltemot.}

$\Lambda$ resident species, often breeding in company with the last; lays two eggs.

Gemus Meraduos.

368. Mergulus alle . . . . . . . Vol. V. Pl. L.

Littile AUK.

Sometimes abundant with us in winter, while in summer it is en. gaged in breeding within the aretic circle.

Genus Fratercula.

369. Fratercula arctica . . . . . . Vol. V. Pl. LI. Puffin.

Numerous among our sea-bounded rocks in summer, and in winter may be found fishing in the bays and shallow portions of our seas.

\section{Family PELICANIDA.}

\section{Subfamily GRACULINA.}

That portion of this family forming the Cormorants comprises about thirty species. They are spread over the rocky sea-shores of the entire globe, with the exception of the ice-bound Poles. In Britain we have two species.

370. Pimllabocorlx clribo . . . . . Vol. V. Pl. LII.

Cormorant.

A denizen of the British waters generally, from which it is never absent.

371. Pralacrocorax araculus . . . . Vol. V. Pl. LIII.

Crested Cormoraxt, or Sirag.

Also a constant frequenter of every part of the British coasts, where it annually breeds.

\section{Subfamily SULARINA.}

The Gamnets form a small section of the Pelicanide. They are truly oceanic in their habits; and are almost as widely distributed as the Cormorants. In species, however, they are far less numerous, only six or seren being known; and should the Australian bird be ultimately proved to be identical with our own, then the number will be still less.

372. Suld Bissina . . . . . . . Vol. V. Pl. LIV. Gandet, or Solan Goose.

I must refer my readers to the body of the work for full 
information respecting this predaceous bird, for it would be out of place to enter into particulars here in what can only be regarded as a mere list of the species inhabiting Britain. I may mention, however, that its specific name is derived from one of its breedingplaces, to which may be added Lundy Island, Ailsa Craig, St. Kilda, Suliskerry in Orkney, \&e.

\section{Family LARID E.}

Mr. Harting, in his ' Mandbook of British Birds,' has included the Gulls and Terus in the same fimily, with which view I acquiesce, for it would be diffieult to draw the line between the termination of the one and the commencement of the other. Whether we regard the Gulls, 'Terns, and Skuas separately or collectively, they may be described as coast-wanderers over the entire globe, but more abundant in the northern than in the southern hemisphere. Their principal food is fish, crustaceans, and other marine animals, but some of them readily eat worms, insects, and garbage. In their plumage they are perhaps the most cleanly of all birds, always maintaining their pure and delicate tints unsullied. There are over one hundred species inhabiting various parts of the globe.

\section{Subfamily LARIN 玉.}

\section{Genus Larus.}

The members of this genus comprise all the large Gulls-birds which, as scavengers'alone, pliy an important part in keeping a wholesome atmosphere. They also prey upon fish, crustaceans, small mammals, and weakly birds.

373. Larus marinus . . . . . . Vol. V. Pl. LV. Great Brack-Backed Goll.

A resident species, breeding round our coasts.

374. Larus fuscus . . . . . . . Vol. V. Pl. LVI. Lesser Black-backed Gull.

Also a resident and breeding species.

375. Larus glaucus . . . . . . . Vol. V. Pl. LVII.

\section{Gradcous Gull.}

A bird of the northern hemisphere generally, whence it is driven sonthward on the approach of winter, at which season it arrives here, as well as in similar latitudes in America. 
376. Lirus istandicus

Iceland Gult.

A beautiful species belonging to the regions of the arctic circle, but frequently coming hither in winter, where it finds a more bearable climate.

377. Larus argentatus . . . . . . Vol. V. Pl. LIX. Herring-Gúl.

A bird we may call our own, since it always enlivens our seas and rocks, especially at the breeding-season.

378. Lirus canug . . . . . . . . Vol. V. Pl. LX.

Comaron Gutu.

A native species, abundant both in summer and winter.

Genus Rissa.

Established for our pretty Kittiwake.

379. Rissa tridactyla . . . . . . Vol. V. Pl. LXI. KiтTIWAKE.

A local resident.

Genus PagophiLa.

380. Pagophila eburnea . . . . . Vol. V. Pl. LXII. IVORY GULe.

Abundant at Spitzbergen and many parts of Greenland. Here in Britain it is rare, and quite accidental in its occurrence.

Genus Rinodostethia.

Established for the beautiful Gull named after Captain James Ross, the celebrated navigator.

381. Rhodostethia Rossí . . . . . . Vol. V. Pl. LXIII. Ross's Gult.

Has been killed two or three times in Britain. The Plate should be referred to to form a just idea of this fairy Gull, whose natural home is within the arctic circle.

\section{Genus Cirroicocepmalus.}

The members of this section of the Gulls have many pleasing traits in their character; thus they have the habit of spending their summer in large communities, and of selecting as a site for 
their breeding-place the inland waters of some marsh or strampy island in the interior of the country. Their interest is also much added to by the circumstance of their being subject to seasonal changes in the colouring of their plumage.

382. Chroicocephilatus ridibundes . . . Vol. V. Pl. LXIV. BLACK-Headed GULL.

A common and resident species.

383. Chrotcocephalus phlidelphia . . . Vol. V. Pl. LXV Bonaparte's Guli.

An ozcasional risitant from its native country, North America.

\section{Genus Hydrocolates.}

Instituted for our well-known Little Gull.

384. Hydroccleus mindtus . . . . . Vol. V. Pl. LXVI. LitTle Gulí.

$\Lambda$ tolerably regular winter visitant, never breeding in Britain.

\section{Genus Xema.}

The beautiful arctic Gull named after the late Mr. Sabine is the type of this genus.

385. Xema Sabint . . . . . . Tol. T. Pl. LXVII.

Sabint's Guld.

An occasional visitor to our islands.

\section{Subfamily STERNIN Æ.}

In this subfamily are contained the various forms of Terns or SeaSwallows as they are popularly termed. Ten species are figured under six genera:-Hydroprogme, Actochetidon, Stcma, Sternula, Gelochetidon, and Hydrochelidon.

\section{Genus Hydroprogne.}

386. Hrdroprogne caspia • . . . . Vol. V. Pl. LXVIII.

Caspian Tern.

An accidental visitor. 
Genus Actocitelidon.

387. Acrochelidon cantraca . . . . Vol. V. Pl. LXIX Sandwiem Tern.

A summer risitant and breeding bird.

388. Actochelidon (?) velox.

Swift-flying 'Tern.

A specimen of this bird is said to have been killed in Ireland (see Blake Knox in the 'Zoologist' for 1866). Strictly an eastern bird, and therefore not'figured.

\section{Genus Sterna.}

389. Sterna imrundo . . . . . . . . Vol. V. Pl. LXX. Common Teres.

A resident species. Breeds in many parts of our southern coasts.

390. Sterna paradisea . . . . . . . Vol. V. Pl. LXXI. Roseate Tern.

A summer visitant. Breeds sparingly on the Scilly and Farne Islands.

391. Sterna M.lcrura . . . . . . Vol. V. Pl. LXXII. Arctic Tern.

A resident species, breeding abundantly around our northern coasts.

392. Sterna fuliginosa.

Sooty Tern.

A bird of almost unirersal distribution. Britain has occasionally been faroured with its visits; still there are few who would give it more than a passing notice in any list of the British birds. One was shot at Wallingford, on the banks of the Thames, on the 21 st of Jume, 1869, and kindly sent for my inspection before it was skimned by Mr. James Gardner, Jun., of Holborn and Oxford Street.

\section{Genus Sternola.}

393. Sterndla mindta • . . . . Vol, V. Pl. LXXIII. Littlue Tern.

A summer visitor. Breeds at Dungeness and many other parts of the south coast of England. 


\section{Genus Gelochelidon.}

394. Gelochelidon avglica . . . . . Vol. V. Pl. LXXIV, Guld-billed Terr.

$A$ bird of the eastern portion of Europe, Africa, and $\Lambda$ sia, and quite an accidental visitant to Britain.

\section{Genus Hrdrochetidon.}

The members of this genus frequent marshes for the purpose of breeding, and deposit their eggs in regular-formed nests of herbage. The entire group consists of about ten species, which are widely distributed over the globe.

395. Hydrochelidon nigra . . • . . Vol, V. Pl. LXXV. Black Tern.

A summer visitant, breeding in several of the marshes of England.

396. Hydrochelidon levcoptera . . . Vol. V. Pl. LXXVI. White-Winged Tern.

An accidental visitor from countries to the south-eastward of our islands.

397. Hydrochelidon letcopareia . . Vol. V. Pl. LXXVII.

WHiskered TERN.

An accidental visitor from Eastern Europe.

Genus Arous.

398. Anous stolides.

Noddy Tern.

A bird common to many seas; it is not therefore surprising that a solitary indiridual has now and then wandered to fish in our waters. It is a common species, very generally known, consequently not figured.

\section{Subfamily STERCORARIINE.}

Genus Stercorarius.

Parasitic Gulls are to a certain extent affined to the Petrels, and for this reason have been placed next them in the present volume. Members of this group, which are eight or ten in number, frequent the seas of both hemispheres, are tyrants of the ocean, waging war and domineering over all the birds, and robbing them of the fish they have taken. 
399. Stercoraries catarrhactes - . Vol. V. Pl. LXXVitt. Great ShUa.

Found all round our seas at one season or the other. Breeds in the Orkneys.

400. Stercorariug pomatorhondes . . . Vol. V. Pl. LXXIX. Pomatorhine Skua.

$\Lambda$ constant winter visitor. Breeds in Lapland and Finmark.

401. Stercorartus parasiticus . . . . Vol. V. Pl. LXXX. Arctic Skua.

Resident around our coasts. Breeds in Orkney and Shetland.

402. Stercorarius longicaudus . . . Vol. V.Pl. LXXXt. Long-Tailed SkUa.

A rare winter visitant from the north-eastern seas.

\section{Family PROCELLARID E.}

This truly oceanic family is but feebly represented in the British seas, six or seven being all that we enumerate; whereas with those frequenting the waters of the other parts of the globe they amount to double that number.

\section{Genus Procellaria.}

403. Procellaria glacialis . . . . Vol. V. Pl. LXXXII. FUlmar.

Frequents the British seas generally. Breeds on the island of St. Kilda in countless multitudes.

\section{Genus Puffinds.}

Three or four birls of this form frequent the seas of the British Islands, two of which have been figured, and there can be no doubt as to the propriety of so doing; but I may state that there are others occasionally found here which are not well understood, or have not been properly worked out. Having myself collected these birds round the entire globe, I could not fail to remark the rast number of species I met with. In my 'Birds of Australia' forty species are either figured or enumerated, and I feel assured that the list may be greatly added to on a closer research than I could give of the seas I had at that time (1838-41) the opportunity of traversing. 
404 Puffinds major

Vol. V. P1. LXXXIII. Greit Sirearwater.

$A$ bird which almost yearly visits the seas of the Land's End.

405. Puffinds anglordi . . . . . Vol. V. Pl. IXXXIV. Manx Shearmater.

Breeds commonly on one or more of the Seilly Islands; and, as it is also found here in winter, it may be considered a resident species.

\section{Genus Estrei.utı.}

406. Estrfinata ilesitata.

Capped Petrel.

Has once been taken in England.

Genus Timalassidroma.

A genus in which Vigors and others have placed the smaller members of the Procellaride -.Storm-Petrels. In the British seas we have two breeding species, and a third looks in upon us now and then when it has crossed the Atlantic to our side of the globe.

407. Thalassidroma Leachi . . . . Vol. V. Pl. LXXXV. Fork-tailed Storir-Petrel.

Breeds in the Outer Hebrides, and frequently found dead on inland properties, apparently from exhaustion, from the exertion of crossing overland from sea to sea.

408. Thalassidroma pelagica • . . Vol. V. Pl. LXXXVI. Storu-Petrex.

This little sprite of the waters is known to breed on many parts of our western coasts from the Scilly Isles to the Orkneys, and on some of the rocky islets of the west coast of Scotland.

\section{Thamassidroma Bulweri.}

Bulwer's Petrel.

This bird, which inhabits Madeira, sometimes visits our seas, and by Yarrell and others has been included in our arifauna. 



\section{LIST ()F SUBSCRIBERS.}

HER MOST GRACIOUS MAJESTY THE QUELA. HIS ROYAL HIGHNESS THE PRINCE CONSOR'T.

HIS MLJESTY LEOPOLD I., KING OF THE IEIGIAN's. HIS ROYAL HIGHNESS THE I)UKE D'AUMALE.

Ackroyd, E., Esq., Halifax, Yorkshire.

Adrocates, the Library of the Faculty of, Edinburgh.

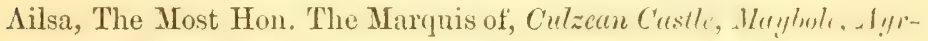
shire, N.B.

Allford, Mrs., Albert Road, Dyke Road, Brighton.

Allison, R. A., Esq., Scaleby Hall, Carlisle.

Allport, Morton, Esq., Hobart Town, T'asmania.

Amhurst, W. Amhurst 'T., Esq., Diellington P'arli, Brendon, Lorfolk.

Anstice, J., Esq., Madeley Wood, Wallington, Salop. 2 copies. Argyll, His Grace the Duke of, Inverary Castle, Aryyllstive, Se. Arkwright, Miss C. E., Mark Hall, Harlow, Essex. Armstrong, Sir W. G., Elswick, Newcastle-on-Tyne. Army and Navy Club, The, Pall Mall. Athenæum; The, Pall Mall. Australian Museum, The, Sydney, New South Wales. Aylesford, The Rt. Hon. The Earl of, Packington Hatl, C'onntiy.

Backhouse, A., Esq., Darlington, Durham.

Bagot, The Rt. Hon. Lord, Blithifeld, liugeley, Staffordstive. Bailey, Mrs. Henry, Roseclale, Tenbury, Worcestershive. Baker, W. R., Esc., Bayfordbury, Hertfordshive. Balston, The Rev. Dr., The Vicuraye, Butcuell, Derhyshir. 
Bamard, H. R., Esq., Worstead, Norwich.

Barclay, Hanbury, Esq., Midlleton Hall, Tamworth.

Barelay, J. G., Esq., Lombard Street, and Leyton, Essex.

Barclay, R., Esq., Lombard Street.

Baring, E. C., Esq., 37 Charles Street, Berleley Square.

Barlow, F. P., Esq., 26 Rutland Gate, Hyde Park.

Barthés, Mons. P., Paris.

Bass, M. T., Esì., 101 Eaton Square, and Ranyemore House, Burtonon-Trent, Staffordshive.

Basset, J. F., Esq., Tehidy Park, Redruth, Cornwall.

Bateman, J., Esq., 9 Hyde-Park Gate South.

Bateson, J., Esq., Shicldair of Gairloch, Achnasheen, Ross-shire, N.B.

Bayne, W. T., Esq., Tork Terrace, Regent's Park.

Bazley, T. Sebastian, Esq., Hartherop Castle, Fairford, Gloucestershive.

Beaumont, A., Esq., Greave, Meltham, Huldersfield, Forlishire.

Beckwith, W. E., Esq., Eaton Constantine, Wrllington, Salop.

Bedford, His Grace The Duke of, Wolum Abbey, Bedfordstive.

Bennett, Dr., Sydney, New South Wales.

Berlin, the Royal Library of.

Betts, Edw. Ladd, Esq.

Bidder, G. P., Esq., Ravensbumy Park, Mitcham, Sumey.

Bird, W. F. W., Esq., Wilmington House, Dartford, Kent.

Birkbeck, E., Esq., I0 Upper Brook Street, Grosvenor Square.

Birkbeck, R., Esq., 20 Berkeley Square.

Birmingham Public Library, 'The.

Blake, H. W., Esq., 8 Devonshire Place, Portland Place.

Bodleian Library, The, Oxford.

Bond, F., Esq., 203 Adelaide Road, South Hampstead.

Booth, E. T., Esq., 18 Vemon Terrace, Brighton.

Boynton, Sir Henry, Bart., Burton Agnes, Yorkshire.

Bradford, The Rt. Hon. The Earl of, Belgrave Square.

Braikenridge, The Rev. G. W., Clevedon, Somersetstire.

Braithwaite, Dr., Clapham Rise.

Brassey, T., Esq., 156 Loundes Square.

Braybrooke, The Rt. Hon. Lord, Audle? End, Saffron Walden, Essex.

Bree, Dr., East Hill, Colchester, Essex.

Bree, The Rer. W., Allestey Rectory, near Coventry.

Brenchley, Julius L., Esq., Milgate, near Maidstone, Kont. 
Brewin, R., Esq., Ide, Ex'eter.

British Museum, The.

Brooke, The Rev. J., Haughton Hall, Shiffnal.

Brooke, T., Esq., Sheffield.

Brooke, Sir Victor A., Bart., Colebrooke Park, Brookeboro', Fermanagh, Ireland.

Brown, J., Esq., Copgrove Hall, Borobridge, Yorkshire.

Brown, W. R., Esq., Belmont House, Liverpool.

Brownlow, The Rt. Hon. The Earl, Belton House, Grantham, Lincolnshire.

Brussels, The Royal Library of.

Buccleuch and Queensbury, His Grace The Duke of, Dalkeith P'uluce, near Edinburgh.

Buchanan, Mrs, Auchtentorlie, Bowting, Dumbertonshire, N.B.

Buckley, H., Esq., Edgbaston, Birmingham.

Buckley, T., Esq., Westwood House, Beverley.

Buckley, Miss, Bank House, Hanley, Stuffordshive.

Buffalo Natural History Society, The, N. America.

Burnett, F. C., Esq., Vauxhall.

Busk, J., Esq., Codicote Lodge, Welwynn, Hertfordshive.

Butler, C., Esq., 3 Connunght Place.

Buxton, Sir T. F., Bart., Warlies, Waltham Abbey, Essex.

Buxton, S. Gurney, Esq., Norwich.

Cabbell, B. B., Esq., Cromer Hall, Norfolk.

Calthorpe, The Rt. Hon. Lord, Grosvenor Square.

Cambridge University, The.

Campbell, Colonel, Blythswood, N.B.

Campbell, Sir George, Bart., Garscube, Glasgow, N.B.

Canada, The Library of the Parliament of.

Cator, A., Esq., Woolbastwick Hall, Norwich, and Trewshury, Cirencester, Gloucestershire.

Chesham, The lit. Fon. Iord, Chesham, Latiners, Buckinghamshire.

Childers, J. W., Esq., Cantley, Doncaster, Yorkshire.

Cholmeley, The Rev. J., Magdalen Hall, Oxford.

Clamorgan, The Cheralier, Normandy.

Clark, E., Esq., 3 TVestminster Chambers, Victoria Street.

Clarke, J., Esq., Fainy Croft, Saffron Waldon, Essea.

Climenson, The Rer. Joln, Stiplake Vicarage, Hentey-on-Thanes, 
Codrington, Lady Georgiana, Doddington Park, Chippenham, Wiltshire.

Collin, J. T., Esq., Wenden, Saffron Walden, Essex.

Collins, Edward, Esq., Newton Ferrers, Callington, Cornwall.

Cooper, Lieut.-Col. Edward F., 5 Bryanston Square.

Cooper, Sir Daniel, Bart., 20 Princes Gardens.

Cotes, Lady Louisa, Woodcote, Newport, Salop.

Cotton, H. P., Esq., Quex Park, Isle of Thanet.

Coulthurst, W. M., Esq., Streatham, Surrey.

Cowper, The Rt. Hon. The Dowager Countess, 4 St. James's Squure.

Czarnikow, C., Esq., Glen Court, Mitcham, Surrey.

Craufurd, The Rev. C. H., Old Swinford, Stourbridye, Worcestershire.

Craven, The Rt. Hon. The Earl of, Charles Street, Berkeley Square.

Crewe, Sir John H., Bart., Calke Abbey, near Derby.

Crewe, Lady, Calke Abbey, near Derby.

Crewe, The Rev. H. H., The Rectory, Drayton Beauchamp, Tring, Hertfordshire.

Crichton, A. W., Esq., Broadward Hall, Aston-on-Clun, Salop.

Crokat, C. F., Esq., Bayswater.

Crommelin, J. P. A. Van Wickevoort, Esq., Haarlem.

Crompton-Roberts, C. H., Esq., 16 Belgrave Square.

Crossfield, H., Esq., Oaklands, Aigburth Road, Liverpool.

Crowley, A., Esq., Croydon, Survey.

Crowley, P., Esq., Waddon House, Croydon, Surrey.

Cubitt, J., Esq.,Great George Street, Westminster.

Darbishire, R. D., Esq., Victoria Park, Manchester.

Darnley, The Rt. Hon. The Earl of, Hill Street, Berlieley Square; Cobham Hall, Kent, \&c.

Darby, Mrs. A., Stanley IIall, Bridgenorth, Salop.

Dartmouth, The Rt. Hon. The Earl of, Patshull Hall, Wolverhampton.

Daubuz, The Rev. J., Killion, Truro, Cornwall.

Davey, R., Esq., Bachym House, Helstone, Cornwall.

Deacon, J., Esq., Birchin Lane, Lombard Street.

Deedes, W., Esq., Sandling Park, near Hythe, Kent.

Denison, A., Esq., 6 Albemarle Street.

Denison, Mrs., 33 Wilton Place, Belgravia.

Dennistoun, A. H., Esq., Rosslea, Helensburgh, N.B.

De Vitré, Mrs., 10 Upper Brunswick Place, Brighton.

Deritt, T. L., Esq., Lower Clapton. 
Devonshire, His Grace The Duke of, Chatsurorth, Derbyshire.

Dickens, C. S., Esq., Coolhurst, Horsham, Sussex.

Dickinson, J., Esq., Abbots Hill, Hemel Hempstead, Hertfordshire.

Dickinson, J. D., Farncomb Place, Godalming, Surrey.

Dod, The Rev. C. Wolley, Eton College.

Dorchester, the Rt. Hon. Lord, Greywell Hill, Odiham, Hampshire.

Dowsett, A., Esq., 16 North Street, Brighton.

Drummond, R., Esq., Charing Cross.

Drummond-Hay, Col., Seggieden, Perth, N.B.

Ducie, The Rt. Hon. The Earl of, Tortworth Court, Gloucestershire.

Dusacq, The Baron, Virginia.

Dutton, The Hon. Edward Lonnox, 2 St. James's Place.

Eckersley, Jas., Jun., Esq., Burnt House, Chorley, Lancashire.

Edinburgh, The Royal Society of.

Edinburgh, The University of.

Edwardes, Capt. J. T. Hope, Netley Hall, Salop.

Edwardes, Sir Henry, Bart., Orleton Hall, Salop.

Elger, J., Esq., Lewes Crescent, Brighton.

Elliot, D. G., Esq., New York.

Elliot, G., Esq., Great George Street, Westminster, and Betley Hall, Betley, Staffordshire.

Ellis, J. H., Esq., Knighton, near Leicester.

Elwes, J. H., Esq., Coleborne Park, Cheltenham.

Enniskillen, The Rt. Hon. The Earl of, Florence Court, Enniskillen, Ireland.

Erle, The Rt. Hon. Sir William, Bramshott Giange, Liphook, Hampshire.

Errington, G. H., Esq., Lexden Park, Colchester, Essex.

Erans, J., Esq., Nash Mill House, Hemel Hempstead, Hertfordshire.

Eyton, T. C., Esq., Eyton-on-the-Wealdmoors, Wellington, Salop.

Falmouth, The Rt. Hon. The Viscount, 2 St. James's Square, and Tregothnan, Cornwall.

Fanshawe, J. G., Esq., Halkin Street, Belgrave Square.

Farlow, C., Esq., St. Edmund's T'errace, Primrose Hill.

Finney, W., Esq., Formosa Place, Cookham, Berkshire.

Fitz-Gerald, Mrs., 2 Portland Place.

Fitzgerald, R., Esq., Adraville, Balmain, New South Wales.

Fitzwilliam, The Rt. Hon. Earl, 4 Grosvenor Square.

Fleming, J., Esq., Quecn's Gate, Kensingten. 
Flower, E. F., Esq., The Hill, Stratford-on-Avon, Wuruichshire. Foley, The Rt. Hon. Lord, 26 Grosvenor Square.

Foljambe, F. J. S., Esq., Osberton, IVorksop, Nottinghamshive.

Ford, J. W., Esq., Enfield Old Park, Middlesex.

Foster, S. L., Lsq., Old Park Hall, Walsall, Staffordshire.

Foster, R., Esq., The Castle, Lostwithiel, Cormwall.

Foster, W. O., Esq., Apley Park, Bridgenorth, Salop.

Fountaine, E., Esq., Easton, Norwich.

Fowler, F. S., Esq., Mannamead, Plymouth.

Fowler, J., Esq., Thom

Fowler, W., Esc., Whittington IIall, Chesterficld, Derbyshire.

Franklin, Lady, 2 Upper Gore, Kensington.

Fraser, W., Esq., Shipness Castle, Argyllshire.

Fuller, F., Esq.

Gardner, C. D., Esq., The Ceclars, Putney.

Gardner, S., Esq., Archer House, Abbeydale, Sheffield, Torkshire.

Gassiot, J. P., Esq., Jun., 6 Sussex Place, Regent's Park, and The Culvers, Carshalton, Surrey.

Gibbs, H. H., Esq., St. Dunstan's, Regent's Park.

Gibson, G. S., Esq., Saffron Walden, Essex.

Glasgow University, The.

Glyn, Mrs. St. Leger, Bramble Hill, Lyndhurst, Hampshire.

Glyn, Sir Richard Carr, Bart., Leweston, Sherborne, Dorset.

Godfrey, T. S., Esq., Balderton Hall, Newark, Nottinghamsthire.

Godman, F. Du Cane, Esq., Park Hatch, Gorlatming, Surrey.

Gosford, The Right Hon. The Earl of, Gosford Castle, Aimagh, Ireland.

Gould, The Rev. A., Biddicot, Banbury, Oxon.

Gower, The Hon. E. F. Leveson, 14 South Audley Street.

Gower, W. Granville Leveson, Esq., Titsey Park, Godstone, Surrey. Graham, The Rev. Ir. R., Arthuret, Carliste.

Gray, A., Esq., Stamford Hill, Middlesex.

Greene, The Rev. R., Highlands, St. James Road, Tunbridge Wells, Kent.

Grenfell, Mrs., Taplow Court, Taplow, Bucks.

Griggs, M., Esq., Plymouth,

Grosvenor, The Lord Richard, 76 Brook Street, Grosveno, Square.

Gulson, J., Esq., Priory Row, Coventry.

Hamilton, Dr., 9 Portugal Street, Grosvenor Squars. 
Hamilton and Brandon, His Grace The Duke of, The Puldere, Humilton, N.B.

Hammond, W. O., Esq., St. Alban's Court, Wingham, Kent.

Hamond, A., Esq., Westacre, Swaffham, Norfolk.

Hanbury, Robert, Esq., Poles, Ware, Hertfordshire.

Hanker, J. A., Esq., Bulcombe Place, Cucl.field, Sussex.

Harcourt, E. W. Vernon, Esq., Nunchem Park, Abingdon, Berkshir.

Hardy, C. S., Esq., Chilham Castle, Canterbury.

Hardy, H. C., Esq., Anstey Manor, Hampshive.

Harrison, W., Esq., Samlesbury Hall, Preston, Lancashire.

Hartley, L. L., Esq., 13 Great Cumberland Place, Hyde Park.

Hartmann, James, Hyndburn, Acerington, Lancashire.

Hartopp, Sir John, Bart., Four Oaks Hall, Sutton Coldficle.

Hartree, Mrs., Lewisham Road, Greenwich, Kent.

Harrey, N., Esq., Hayle, Cormwall.

Hawkshaw, Sir John, Hollycombe, Sussex.

Hawkshaw, J. C., 25 Cormuall Gardens, South Kensingtun.

Hawley, Sir Joseph, Bart., 34 Eaton Place, S.W.

Hemans, G. W., Esq., 11 Roland Gardens, South Kensington.

Hesketh, Sir Thomas, Bart., Rufford Hall, Ormskirk, Lanceshive.

Hewitson, W. C., Esq., Oatlands, Walton-on-Thames.

Hill, The Right Hon. Viscount, Hawhestone, near Strensbury, Salop.

Hoare, S. G., Esq., Hampstead, Middlesex.

Holford, R. S., Esq., Dorchester House, Park Lane.

Holland, Wilmot, Esq., Bread Street, Cheapside.

Holmes, A. W., Esq., Makeney Lodge, Derby.

Holmesłale, The Rt. Hon. Viscount, Linton Park, Staplelur'st, Kent.

Hope, The Lady Mildred Beresford, 1 Connaught Place.

Horsfall, W. C., Esq., Horsforth Low Hall, Leeds, Yorkshire.

Hudson, R., Esq., Clapham Common.

Hull Subseription Library, The.

Hussey, H., Esq., Hyde Park Gardens.

Huthwaite, The Rev. T. W., Backwell Vicarage, Bristol.

Ingram, Mrs., Mount Felix, Walton-on-Thames.

Irving, Professor, Melbourne, Victoria, Australia.

Isham, Sir Charles E., Bart., Lamport Hall, Northampton.

Jeffery, G. A., Esq., Trinity House, Eastbourne, Susser?.

Jervoise, H. E., Esq., 11 Eaton Terrace.

Johnstone, Sir Harcourt, Bart., 34 Belgrave Squdre. 
Jolliffe, The Hon. H. H., Merstham, Surrey.

Jones, Mrs., The Vicarage, Baschurch, Salop.

Jones, H., Esq., Birmingham.

Kelk, J., Esq., The Priory, Stanmore, Middlesex.

Kelsall, H., Esq.

Kemp, J. Y., Esq., 41 Weymouth Street, Portland Place.

Fennard, II. MI., Esq., Crumlin Hall, Newport, Monmouthshive.

Knight, E., Esq., Chawton House, Hampshive.

Korshaw, S., Esq., Heywood, Munchester.

King's College, Cambridge, The Provost and Fellows of.

Kyngdon, Boughton, Esq., Tregeare, Croydon, Surrey.

Larking, J. W., Esq., The Firs, Lee, Kent.

Laver, H., Esq., Trinity Street, Colchester, Essex.

Lawley, 'The Hon. and Rev. S. W., Escrick, near York.

Tawrence, E. II., Esq., Abley Furm Lodge, New Finchley Roud. Hampstead, Middlesex.

Lawrence, G. N., Esq., Pearl Street, New York:

Leaf, C. J., Esq., Old Change, City.

Teigh, The Rt. Hon. Lord, Stoneleigh Abbey, Kenitworth, Warwicl:stire.

Lilford, The Rit. Hon. Lord, Lilford IIall, Oundle, Nosthamptonsthive. Liverpool Library, The.

Liverpool Free Library, The.

Llewelyn, J. D., Esq., 39 Cormuall Gardens, Kensington.

Tondonderry, The Most Hon. The Marquis of, Mount Stcwart, Neu'townards, Co. Down, Ireland.

Longman, C., Esq., Shendish, Hemel Hempstead, Herlfordshire.

Longman, T., Esq., Farnborough Hall, Famborough.

Longrnan, W., Isq., Ashlyn's Hall, Berlhampsteal, Hertfordshire.

Lucas, 'I., Esq., 12 a Kensinyton Palace Gardens.

McComnel, Miss J. C., Cresshrook, Buliewell, Derbyshire.

Major, (). M., Tisq., C'romuell House, Duppas Hill Terrace, Croydon, Surrey.

Malta, The Public Library of.

Manchester, His Grace The Duke of, Grect Stanhope Strect, and Kimbolton Castle, St. Neot's, Huntingdonshire.

Mansel, G. 1'., Lisq., Langton Lodge, Blandford, Dorset.

Mansficld, H., Esq., Oreford and Cumbridye Club, Pall Mull. 
Marjoribanks, Miss Emma, 34 Wimpole Street, Cavendish Square.

Marlay, C. B., Esq., St. Katherine's Lodge, Regent's Park.

Marshall, J., Esq., Belmont, Taunton, Somersetshire.

Marshall, W., Esq., Clay Hill, Enfield, Middlesex.

Marshall, W., Esq., Patterdule Hull, Penrith, Cumberlund.

Martens, G., Jun., Esq., Hamburg.

Matheson, of Ardross, Mrs., 38 South Street, Grostenor Square.

Mercer, D., Esq., West Drayton, Middlesex.

Michell, J., Esq., Foreett Park, Darlington, Durhum.

Hicklethwait, The Rev. J. N., Taverham Hall, Norvich.

Mildmay, H. B., Esq., 46 Berkeley Square.

Mildmay, Sir Henry St. John, Bart., Dogmersfield Perk, Hewn,shive.

Nilles, The Hon. George, Lee's Court, Fuversham, Kont.

NIiher, Sir William M. E., Nunappleton, Tradecester, Yorkshir.

Milton, The Rt. Hon. Selina, Viscountess, Carlton Housc Terioret.

Mitchell, A., Esq., 6 Great Stanhope Street, May Fair.

Nolyneux, Sir Capel, Bart., C'astle Dillon, Aimergh, Irelend.

Monfort, C., Esq., 33 Marine Parade, Worthiny, Sussex.

Monk, 'I. J., Esq., Mountfield House, Lewes, Sussex.

Moore, J., Esq., Grasmere Lodge, Lower Tulse Hill.

Morella, The Countess de, Wentworth, Staines.

Morley, Miss L., Windmill, Blackheath, Kent.

Morrison, of Bognie, A., Esq., Mountblainy House, Inurners.

Morse, C., Esq., The Orchard, Aylsham, Norfoll:

Murdoch, J. B., Esq., 33 Lynedoch Street, Glasgow, N.B.

Musgrave, Sir Richard C., Bart., Eden Hall, Penvith, C'umbentruel.

Naylor, J., Esq., Leighton Hall, Welchpool.

Necker, F., Monsr., Geneva, Switzerland.

Neweastle, His Grace The Duke of, Clumber, Nottinghamshire.

Newdigate, Lieut.-Col., Grenadier Guards, Byrliley Lodye, Needn no,

Forest, Buiton-upon-Trent, Steffordshive.

Newdigate, Major.

Newman, E., Esq., Barnsley, Yorkshive.

Nichol, J. C., Esq., Merthy. Mawr, Bridgend.

Nicholson, F., Esq., Bowden, Cheshire.

Noble, J., Esq., Park Place, Henley-on-Thames, 2 copies.

Nolan, Dr., Gerald's Town, Ireland.

Norris, W. G., Esq., Colebrookdale, Sulop.

North, The Rt. Hon. The Baroness, 16 Arlinyton Strect, Piccadilly. 
Northampton, The Most Hon. The Marquis of, 145 Piccutilly, and Castle Ashby, Northamptonshire.

Northumberland, His Grace the Duke of, Almwick Custle, Northumberland.

Ourry, F., Esq., 12 Queen Anne Street, Cuvendish Square.

Owen, Professor, Sheen Lodge, Richmond Park.

Oxford and Cambridge Club, Pall Mall.

Packe, J., Esq., Lelton Lodge, Woodbridge, Suffolk.

Palatine Library, The, Florence.

Parker, Mrs., Whiteway House, Chudleigh, Devonshire.

Peabody Institute, The, Baltimore, N. America.

Peek, H. W., Esq., Wimbledon House, Wimbledon, Sumey.

Pender, J., Esq., 18 Arlington Street, Piccadilly.

Penrice, T., Esq., Kilvrough House, Swanseu, South Wales.

Peurhyn, The Rt. Hon. Lord, Penrhyn Castle, Bangor.

Perkins, J., Esq., Downing College, Cambridge.

Peters, W., Esq., Ashfold, Crawley, Sussex.

Peto, Sir S. Morton, Bart.

Philadelphia Academy of Sciences, The, North America.

Pinwill, Captain, Trehane, Tresilian, Probus, Cornwall.

Plymouth Public Librars, The.

Pocock, Mrs., Puckrup Hall, Tewhesbury, Gloucestershire.

Portland, His Grace The Duke of, Cavendish Square.

Portman, The Hon. Mrs., Durveston, Blandford, Dorset.

Powerscourt, The Rt. Hon. Viscount, Pouerseourt House, Wiclilum,

Ireland.

Powys, P. Lybbe, Esq.

Prentice, Walter, Esq., Rainham, Kent.

Pryor, R., Esq., High Elms, Watford, Hertfordshire.

Radcliffe Library, The, Oxford.

Ramsay, E. P., Esq., Dobroyde, New South Wales.

Ravensworth, The Rt. Hou. Lord, Ravensworth Custle, Giateshead, Durham.

Reed, W., Esq., York.

Reeres, J. R., Esq., Woodhays, Wimbledon, Surrey.

Ridgway, J., Esq., Brandfold, Goudhurst, Kent.

Rigby, S., Esq., Warrington.

Rimmer, R., Esq., The Gables, East Bergholt, Colchester, Essex. 
Ripon, The Most Hon. The Marquis of, Cartton House Gardens.

Rocko, J., Esq., Clungunford House, Aston-on-Clun, Salop.

Rodd, E. H., Esq., Penzance, Cornwall.

Rolle, The Rt. Hon. Lady, Upper Grosvenor Street, and Bicton, Budleigh Salterton, Devon.

Rolle, 'The Hon. Mark, Stevenston, Devonshire.

Rooper, G., Esq.

Rotherham, Mrs., Conuden, Coventry.

Rothschild, Sir Anthony de, Bart., Grosvenor Place Houses.

Rothschild, Miss Alice de, Aston Clinton, Tring, Hertforlshire.

Rothschild, The Baroness, 107 Piccadilly.

Rowley, G. Dawson, Esq., Chichester House, East Cliff, Brighton.

Rowley, J. T., Esq., Tendring Hall, Stoke-by-Nayland, Colchester,

Essex.

Royal Artillery Institution, The, Wootwich, Kent.

Royal Institution of Great Britain, The, Albemarle Stieet.

Rucker, S., Esq., West Hill, Wandsworth, Surrey.

Ruskin, J., Esq., Corpus Christi College, Oxford.

Russell, J. Watts, Esq., Mam Hall, Ashborne, Derbyshire.

St. Andrews, The University of.

St. Petersburg, The Imperial Academy of Sciences of.

St. Aubyn, Sir John, Bart., Trevethoe and Pendree, Cornuall.

Sanford, W. A., Esq., Nynehead Court, Wellington, Somersetshive.

Saunders, Howard, Esq., 7 Radnor Place, Gloucester Syuare.

Schreiber, Mrs., Woodchurch, Ashford, Kent.

Scott, A. J., Esq., Rotherfield Park, Alton, Hampshire.

Scott, E. H., Esq., 27 Grosvenor Square.

Scott, T., Esq., Ann Street, Birmingham.

Sefton, The Rt. Hon. The Earl of, Belgrave Square.

Shaw, Mr. Henry, Shrewsbury.

Shuttleworth, R. J., Esq., Berne, Switzerland.

Sibthorp, Mrs. Waldo, Washingboro', Lincoln.

Simmons, G., Esq., East Peckham, Tonbridge, Kent.

Sion College, London Wall.

Skaife, J., Esq., Union Street, Blackburn, Lancashire.

Skinner, C. B., Esq., 57 Eccleston Square.

Slater, Edwin, Esq., Manchester.

Smith-Dorrien, Thos. Algernon, Esq., Tresco Abbey, Isles of Scilly.

Smith, A. H., Esq., Flexford House, Guildford, Surrey.

Smith, Rev. Oswald, Crudwell Rectory, Tetbury, Gloucestershire. 
Smith, W. C., Esq., Shortgrove, Newport, Essex.

Smyth, Perey, Esq., Headborough, Ireland.

Smyth, Sir J. H. Greville, Bart., Ashton Court, near Bristol, Somersetshire.

Solly, W. H., Esq., Serge Hill, Hemel Hempstead, Hertfordshire.

Sondes, The Rt. Hon. Lord, 32 Grosvenor Square.

Sotheran, Messrs. H. \& Co., 136 Strand. 2 copies.

Spicer, Major, Spye Park, Chippenham.

Spottiswoode, W., Esq., 50 Grosvenor Place.

Stamford and Warrington, The Rt. Hon. The Earl of, Enville Hall, Staffordshire.

Stane, Bramston, Esq., Buckfield, Basingstoke, Hampshire.

Stanhope, J. Banks, Esq., Revestey Abbey, Boston, Lincolnshire.

Staniforth, The Rev. Thomas, Storr's Hall, Windermere, Westmoreland.

Stapleton-Cotton, The Hon. R.

Stevenson, H., Esq., Norwich.

Stewart, Captain.

Stewart, H. G. Murray, Esq., Cally Gatehouse, N.B.

Stewart, M. J., Esq., Arkwell, Stranraer, N.B.

Stracey, Sir Henry, Bart., Rackheath Hall, Norwich.

Stuart, R. L., Esq., New York, N. America.

Stuart, The Rev. H. C., Weagly Vicarage, Wakefield, Yorkshire.

Sturt, H. G., Esq., Crichel, Wimborne, Dorset.

Surgeons of England, The Royal College of, Lincoln's Inn Fields.

Sutherland, His Grace The Duke of, Stafford IIouse, St. James's.

Sutton, E. G. G., Esq., Grange Villa, T'ring, Hertfordshire.

Tankerville, The Rt. Hon. The Earl of, Chillingham Castle, Northumberland.

Tarratt, J., Esq., Duddon Hall, Broughton-in-Furness, Lancashire. Taylor, E., Esq., Castle Cottage, Hockerill, Essex.

Taylor, J. E., Esq., Manchester.

Taylor, W., Esq., Thorne House, Eastbourne, Sussex.

Temple, The Rev. G., Canterbury, Kent.

Teylerian Library, The, Haarlem.

Thomasson, J. P., Esq., Moorfield, Bolton-le-Mloors, Lancastire. Thompson, J., Esq., Bowden, Cheshire.

Thompson, W., Esq., Gloucester Row, Weymouth, Dorsetshire.

Tindal, Mrs. Acton, Manor House, Aylesbury, Buckinghamshive.

Tipping, Mrs., Brasted Park, Seven Oaks, Kent. 
Tomline, G., Esq., 1 Carlton House Terrace.

Tottenham, Lt.-Col., Talbot Hall, New Ross, Lieland.

Tremayne, J., Esq., Heligan, St. Austell, Cornwall.

Trevor, Lord A. Hill, Brynkinholt Park, Salop.

Trinity College, Dublin.

Tufton, Sir Richard, Paris.

Turnor, C., Esq., Stole Rochford, Grantham, Lincolnshire.

Tweedie, A. F., Esq., Bickley, Bromley, Kent.

Tweedie, J., Esq., Rachan House, Peebleshire, N.B.

Victoria, The Public Library, Museum, and National Gallery of, Melbourne, Australia.

Vistoria, The National Museum of, Melbourne, Australia.

Walden, The Rt. Hon. Viscount, Walden Cottage, Chislchurst, Kent.

Walker, Fountaine, of Foyers, Esq., Muirtown House, Inverness.

Walker, Mrs., Arnot Grove, Southgate, Middlesex.

Waller, E., Esq., Farmington Lodye, Northleach, Gloucestershire.

Walton, C., Esq., Manor House, Acton, Middlesex.

Ward, Ellis H., Esq.

Warde, Col., Squerryes Court, Westerham, Kent.

Waring, S. L., Esq., The Oaks, Norwood, Surrey.

West, -, Esq., Eccleston, Liverpool.

Wellington, His Grace the Duke of, Apstey House, Piccadilly.

Wenlock, The Rt. Hon. Lord, Escrick Park, near Yurk.

Westerman, G. F., Esq., Amsterdam.

Westminster, The Most Hon. The Marquis of, Grosvenor House, Upper Grosvenor Street. 2 copies.

Wharncliffe, The Rt. Hon. Lord, Wharncliffe House, Curzon Strect, May Fair.

White, F. M., Esq., 4 Sussex Place, Regent's Park.

White, The Rev. H., Stanhope Place.

Whitehead, J., Esq., Burfield Lodge, Bickley, Bromley, Kent.

Whitworth, Sir Joseph, Bart, Chorlton Street, Manchester.

Wigram, L., Esq., 43 Berkeley Square.

Wigram, M., Esq., Moor Place, Much Hadham, Hertfordshire.

Williams, C. H., Esq., Pilton House, Barnstaple, North Devon.

Williams, E. M., Esq., Flushing, Falmouth, Cornwall.

Williams, Sir Frederick M., Bart., Goonvrea, Cornwall.

Williams, G., Esq., Trevince, Truro, Cornwall.

Williams, J. G., Esq., Chequers Court. Tiving, Hertfortshirc. 
Williams, The Dowager Lady, Tregullow, Cormuall.

Willyams, E. B., Esq., Nanskeval, St. Columb, Cornwall.

Wilson, Colonel F. M., Stowlungtoft Hall, Bury St. Edmunds, Suffolk.

Wilson, G. H., Esq., Redgrave Hall, Botesdale, Suffolk.

Wolf, J., Esq., 59 Berners Street, Oxford Street.

Worthington, Jas., Esq., Sale Hall, Manchester.

Wright, S. Beresford, Esq., Aldercar Hall, Nottingham.

Wright, Francis, Esq., Osmaston Manor, Derby.

Wrottesley, Lord, 18 Chapel Street, Park Lane.

Windsor-Clive, The Lady Mary, Oalily Park, Broomfield, Salop.

Wingfield, Captain C., Onslow Hall, Shrewsbury.

Yarborough, The Rt. Hon. The Earl of, 17 Arlington Strect, Piccudilly.

Zoological Society of London, The, Hanover Square. 


\section{P R O S P E C T US}

OF THE WORKS

\section{ONOR N I T II O L O G Y, E'TC.,}

\section{JOHN GOULD, F.R.S.}

\section{THE BIRDS OF GREAT BRITAIN. London, 1873.}

The publication of this work commenced in 1862, and is now complete in twenty-five Parts at Three Guineas a Part, or £78 15s, the whole. Any person desirous of obtaining one of the firt remaining eopies may do so by communicating with the Author.

\section{A CENTLRY OF BIRDS FROM THE HIMILAYA MOCN-} TAINS. 1 Volume, Imperial Folio, containing so Plates, with descriptive letterpress. Price $£ 14$ 14s. London, 1832.

This work, of which no copies remain, was commenced in January 1831, and completed in August 1832. It contains figures and descriptions of 100 Birds which rere at that time either new or ver imperfectly known.

III. THE BIRDS OF ETROPE. j Volumes, Imperial Folio, comprising 449 Plates, with descriptive letterpess, Introduction, \&c. Price $£ 768 s$. London, 1837.

Of this work also no copies remain; and it is a source of much satisfaction to the Author to linow that when a copy is oflered for sale by public auction, on the demive of a Subseriber, it realizes considerably more than its original cost, - in some instances as much as $£ 100$ and even $£ 120$.

IV. THE BIRDS OF A L'TRALIA. 7 Tolumes, Imperial Folio, containing Figures of (iol species, with descriptive letterpress and a large amount of Introductory matter. Price $£ 115$. London, 1848.

This work, of which no copies remain, was originally published in

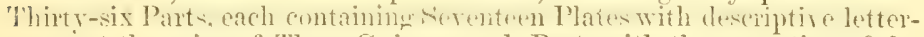
press, at the price of 'Three Guineas each Part, with the exception of the Thirty-sixth, the price of which, in consequence of the large amount of introductory matter, was $\mathbb{R}+12$ s. 


\section{A SUPPLEJENT TO THE BIRUS OF ALSTRALLA.}

Such a work as the "Birds of Australia' could not be kept incomplete for an indefinite period; it was, therefore, brought to a close in 1848, when all the species then linown had been figured; but as dustralia became more and nore known, atditional species of birds were discovered, rendering a Supplement necessary, in order to leep the subject complete. Parts I., II., III., IV., and V., price $£ 33$ s. each, have been published as a suflicient number of novelties came to hand; and with P'art V. Titles and every requisite to form the whole into a Volume have been furnished. This supplementary Volume, containing many novelties of the highest interest, the Author considers to be one of the most important he has produced, whether recrarded as a continuation to the seven volumes which preceded it, or as a separate work. Price 15 Guineas.

\section{A HANDBOOK TO THE BIRDS OF ALS'TRALIA.}

This work has been published in consequence of the Author having been led to believe that a résumé of the subject in an 8vo form, without Plates, would be acceptable to the possessors of the folio edition, as well as to the many persons in Australia who are now turnimg their attention to the Ornithology of the country in which they are resident, and because he was moreover assured that such a work was greatly needed to enable the explorer during his journeyings, or the student in his quiet home, to identify the species that might come under his observation, and as a means by which the curators of the museums, now established in all parts of the world, might arrange and name the Australian birds entrusted to their charge; and he believes that the two rolumes (containing over 600 pages each) in which it is comprised will fully answer the desired end.

'The price of the Two Volumes, which contain a considerable amount of additional and interesting information, and many species not in the folio edition, is $£ 210$ s.

\section{THE BIRDS OF ASIA. In course of publication.}

To no pertion of the globe does there attach so much interest as to that vast extent of the Old World which we designate Asia. It is there that all the productions of nature essential to the well-being of man occur in tho greatest abundance. The most important of our domestic quadrupeds, the most valuable and interesting of our domestic Gallinaceous birds, were first reclaimed in . Isia. It is in Isia that animal life exhibits in its forms the highest degree of ormic development, together with a variety in those forms in aceordance with the varied physical characters of this extensive region, where the wrandest mountain-ranges alternate with steppes, sandy deserts, inland seas, and interminable forests of rigantic growth. That the Zoology, then, of such a country should have called forth the notice and study of able minds cammot be surprising; and yet it is remarkable that no one has attempted a work comprehending a general history of its ORNITHOLOGY. This hiatus in Omithological literiture the Author proposes to fill up by publishing a work on "The Birds of Asin,' precisely similar in every respect to his former workis on 'The Birls of Eurupe 'and 'The Birds of Australia.' Its size and manner of execution will be the same; and it will be published in Parts, price Three Guineas each.

Of this work twenty-five Parts have been published up to 1873; and for the present it will still appear at the rate of not more than one or tro Parts a year. 


\section{A MUNOURAPH OF 'THE RAMPHASTHDE, OR FAMILY}

()E T'UC'\NS. 1 Folume, Imperial Folio, containing Fiftytwo Plates, with descriptive letterpress, \&c. Price $£ 1212$. London, 1854.

An edition of this work was published in 183t, at the price of $£ 7$; but the extensive researches since carried on among the Great Andean Tianges of sonth America having led to the discovery of many ad:litional and beatiful species belonging to this extraordinary group' of Birds, a revision of the work not only became necessary, but an entirely new edition was deemed imperative; and accordingly one, with the whole of the former Plates redrawn, was published in 18.5, at the price of E*12 12s.

The history of this South-American group is very peculiar; and their manners and actions are as rmankible as their aspect, in some respects reminding us of the Iormbills of India and Afrien, while in others they are unlike those of any other group of the feathered race. To a consideration of these points the Introduction is devoted.

\section{A MONOGRAPII OF THE TROGONIDE, OR FAMILY OF TROGONX. 1 Tolume, Imperial Folio, cuntaining Thirty- six Plates, with descriptive letterpress. Price $£ 8$. London, 1838.}

This work, in unison with the Monomalph of the Toucans, comprises the history and fimures of all the species of the group linown up to the date of publication. The members of the Trogonide are remarliable for a gorgeous style of colouring, for recluse labits, and for the union of insect diet with such aliments as fruits and berries, in accordance with which the beak is modified; they are divided between the warmer latitudes of America and India, with the exception of one species, which is peculiar to Africa. With the plumes of some species the Mexican kings and Caciques are said to have adorned their head-dresses.

The same reasons which induced the Author to publish a new edition whe Monoraph of the Ramphastide, have also rendered another edition of this Momoraph de-irable ; and aceordingly one is now in preparation, comprising all the new species and information required respecting this family of birds during the last twenty-five years. It will be completed in four Parts, at $£ 3$ :3s, each, the tirst and second of which is now ready for delivery.

\section{A MONOGRAPII OE THE ODONTOPHORINE, OR} PARTRIDGES OF AMERICA. 1 Volume, Imperial Folio, containing Thirty-two Plates, with descriptive letterpress. Price $£ S$ ss. London, 1850.

The interest which attaches to this work is threefold. First, it displays, even to the most unpractised eye, the broad distinction which subsists between the Partridyes of America and those of Europe; secondly, the specien are all remarlable for the elexance of their forms and for the chaste beauty of their colouring: and thirdly, at no distant date these birds will be regarded in America, as our Partridges in Europe are, as game, and perhaps preserved by law, - their llesh being as delicate for the table as that of our ordinary bird, from which, howesor, they difler considerably in the structure of the beak, and in general habits and economy. 


\section{A MONOGTAPH OF THE TROCIILIDA OR HUM- MING-BIRDS.}

Having from an early period deroted himself to the study of these beantiful birds, and acquired a most valuable and extensive collection of a wroup peculiar to America and its adjacent islands, the Author determined upon publishing a Monograph of a fumily mequalled for the gorgeons and ever-changing brilliancy of their hues, the variety of their form, the singularity of their halits, and the extent of their territorial distribution. Anxious to render his representations of these Invely objects as faithful as possible, the Author instituted a series of experiments upon a new mode of colouring, which has been so fur sucessful that the birds are as closely imitated as art can hope to see accomplished; he has also endeavoured, as far as possible, to associate each species with one of the plants of its own rerion, thereby adding an additional charm to a work which he trusts will be equally acceptahle to the artist and the lover of nature, and which has been so successful that it is perhaps the most popular of his productions.

Complete in five Volumes, price $£ 78$ 15s.

\section{THE MLAIMALS OF AUSTRALIA.}

The Author's visit to Australia having enabled him to procure much valuable information respecting the halits and economy, and many new species, of the singular and interesting Mammalia of that comtry, he has determined upon publishing a work on the sulject. With respect to the importance of such a work no doulbt can exist; and as the author is deeply impressed with this idea, so will he endearour to render it equal to its associate publication on the Omithology of that remarkable region. To the Plates every attention, even to the minutest dotails, has been rendered; and the Author's original notes and observations have furnished him with a store to draw upon for many points of interest. In execution it is precisely similar to the 'Birds,' and is completed in 'Thirteen Parts, each

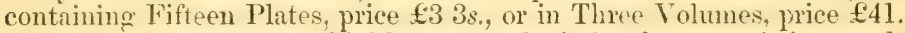

This work has been so highly approved of, that by many it is regarded as more interesting than the 'Birds' of the same country.

With the exception of the 'Handbook to the Birds of Australia,' all the above works are in Imperial Folio, with the Plates and Descriptions in the same style, and form a uniform series.

\section{LONIUON : PUPIISIIED BY TIIT AUTIIOR, 26 CILAROTTE S'IREET, BEDFORD SQUARE, TV.C.}

Angust 1873. 





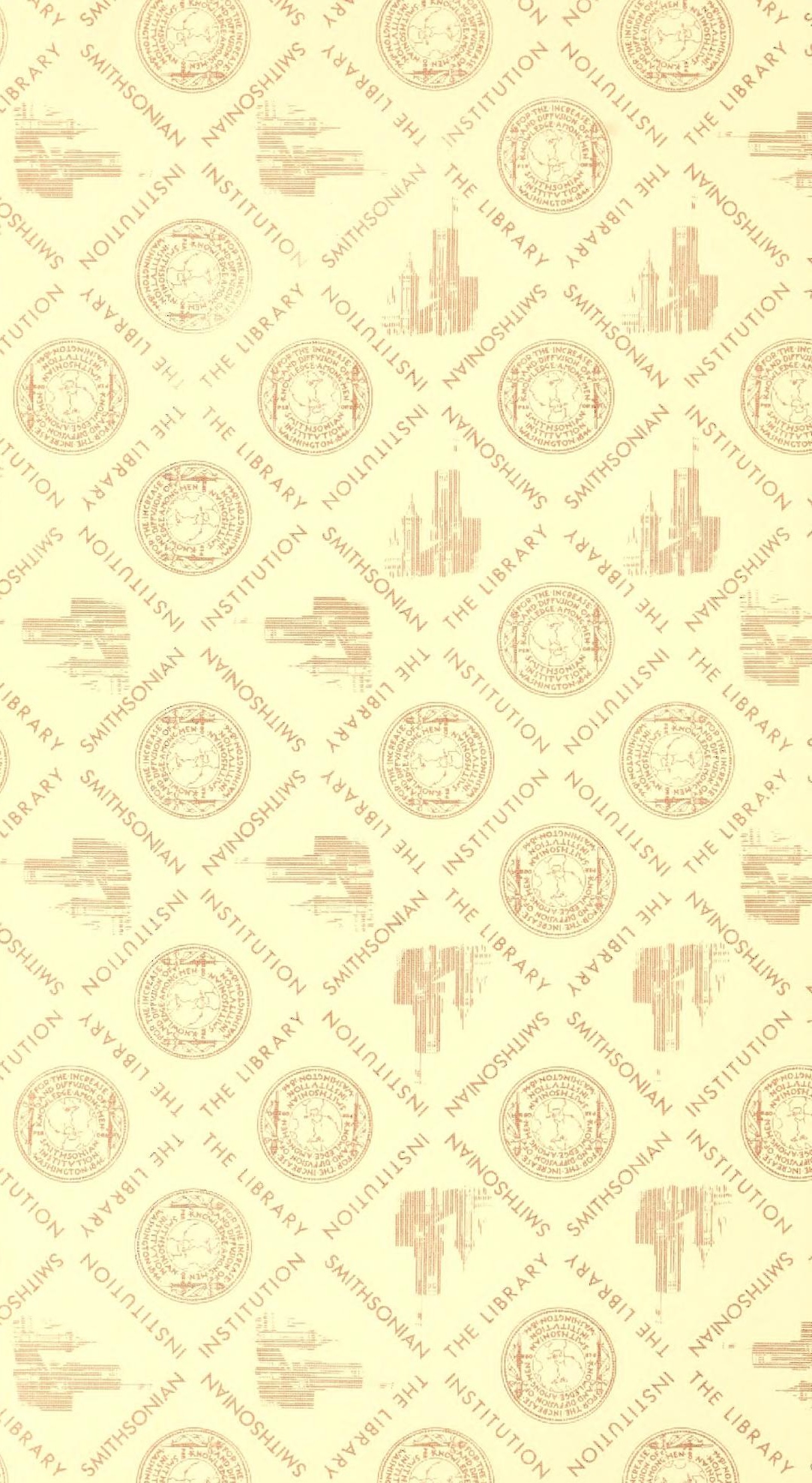




SMITHSONIAN INSTITUTION LIBRARIES 